This dissertation has been microfilmed exactly as received $66-1795$ JOHNSON, Irene, 1931AGRICULTURAL DIVERSIFICATION IN GEORGIA. The Ohio State University, Ph.D., 1965 Geography

University Microfilms, Inc., Ann Arbor, Michigan 


\section{AGRICULTURAL DIVERSIFICATION IN GEORGIA}

\section{DISSERTATION}

\section{Presented in Partial Fulfillment of the Requirements for the Degree Doctor of Philosophy in the Graduate School of The Ohio State University}

Irene Johnson, A.B., M.A.

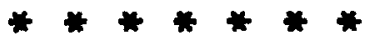

The Ohio state University 1965

Approved by

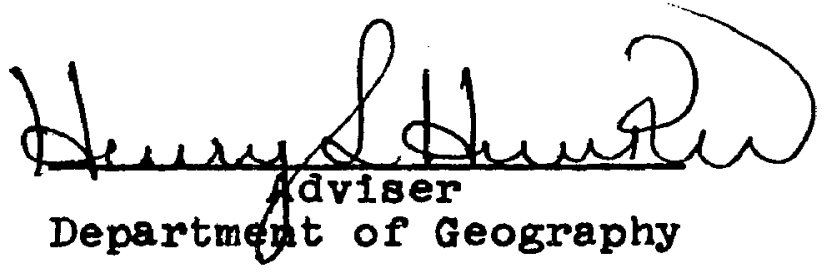




\section{ACKNOWLEDGMENT}

The writer expresses her sincere appreciation to her adviser, Professor Henry I. Hunker who provided encouragement throughout the writing of this dissertation; as well as to Professors Edward J. Taafe and Leslie J. King who gave assistance in the use of statistics. Jerome Clemens and John H. Wlttmann contributed valuable assistance in preparing many of the maps. The writer also expresses gratitude to Professor John F. Hart for the use of his data on the migration of nonwhites and to so many others who contributed to the writing of this dissertation. 


\section{VITA}

\begin{abstract}
January 20, 1931 Born--Atlanta, Georgla
1951 - - - - A.B.--Fort Valley State College, Fort Valley, Qeorgia

1959 - . - M.A.-The University of Wisconsin, Madison, W1sconsin

1964 .....

$1964-65$ - . .

Ass1stant Instructor, The Ohio State University, Columbus, Ohio

Assistant Professor, Florida A. and M. UnIversity, Tallahassee, Florida
\end{abstract}

Major fleld: Geography
FIEIDS OF STUDY 


\section{CONTENTS}

Page

ACKNOWLEDGMENTS . . . . . . . . . . . . 11

TABLES . . . . . . . . . . . . . . . . . v v

ILLUSTRATIONS . . . . . . . . . . . . . . v1

INTRODUCTION ....................... 1

Chapter

I. PHYSICAL BACKGROUND . . . . . . . . 15

II. SOCIOECONOMIC BACKGROUND . . . . . . 34

III. ANALYSIS OF DIVERSIFICATION . . . . . 54

IV. EVALUATION OF HYPOTHESES . . . . . . 106

v. AGRICULTURAL DIVERSIFICATION AND
SOCIOECONOMIC VARIABLES ...... 135

SUMMARY AND CONCLUSIONS . . . . . . . . . . 152

BIBLIOGRA PHY . . . . . . . . . . . . . 162 


\section{TABLES}

Table

Page

1. Employment in Nonagricultural Activity,

by Industry, Atlanta, 1962 ...... 38

2. Frequency Distribution of Gini

Coefficients of Land Use

Diversification, 1939, 1949,

and 1959 . . . . . . . . . . . . 121

3. Frequency Distributions of Gini

Coefficients of Diversification

Based on Value of Farm Products

Sold, 1939, 1949, and $1959 . . . . .129$

4. Factor Loadings for the First $S 1 x$

Factors

\section{CHARTS}

Chart

I. Graphic Schema of Diversification . . . . 115

II. Land Use In Georgia, 1929-59. . . . . . . I20

III. Sources of Cash Income, Georg1a, 1929-59 


\section{ILLUSTRATIONS}

Map

Page

I. Physlographic Diagram of Georg1a . . . . . 16

II. Physlographic Regions of Georgia . . . . . 18

III. Soll Regions in Georgia . . . . . . . . 20

IV. State Economic Areas, Georg1a, 1960 . . . . 35

V. Percentage of Total Population Urban for 105 Georgia Counties, 1960 . . . . . 40

VI. Level of L1ving of Farm Families for 105 Georgia Counties, 1960 . . . . . . 41

VII. Percentage of Farms Having Tractors for 105 Georgia Count1es, 1959 ........ 51

VIII. Gini Coefficients Based on Land Use for 105 Georgia Count1es, 1939 . . . . . . 62

IX. Land Use Diversification for 105 Georgia Count1es, 1939 ............ 63

X. Ginl Coefficients Based on Land Use for 105 Georgia Count1es, 1949 . . . . . . . 68

XI. Land Use DIversification for 105 Georgia Count1es, 1949 .......... 69

XII. Change In Gin1 Coefficients Based on Land Use for 105 Georgia Count1es, 1939-49 . 70

XIII. Gini Coefficients Based on Land Use for 105 Georgla Counties, 1959 ....... . 74

XIV. Land Use DIversification for 105 Georgia Counties, 1959 . . . . . . . . . 75

XV. Change in Gin1 Coefficlents Based on Land Use for 105 Georgia Counties, 1949-59 
XVI. Profiles of Changes in Land Use Diversification for 105 Georgia

Count1es, 1939-49 and 1949-59

XVII. Gini Coefficients Based on Sale of

Farm Products for 105 Georg1a

Count1es, 1939 . . . . . . . . . .

XVIII. Diversification Based on Sale of Farm Products for 105 Georgia Counties, 1939

XIX. GIn1 Coefficients Based on Sale of Farm Products for 105 Georgla Counties, 1949

XX. Diversification Based on Sale of Farm Products for 105 Georgla Counties, 1949

XXI. Change In GInI Coefficlents Based on Cash Recelpts for 105 Georgia Count1es, 1939-49. . . . . . . . 93

XXII. GIn1 Coefficients Based on Sale of Farm Products for 105 Georgla Count 1es, 1959 . . . . . . . . 96

XXIII. Diversification Based on Sale of Farm Products for 105 Georgia Counties, 1959

XXIV. Change in GinI Coefficients Based on Cash Receipts for 105 Georgla Count1es, 1949-59 .......... 98

XXV. Profiles of Changes in Income Diversification for 105 Georgia Count1es, 1939-49 and 1949-59

XXVI. Core Cotton-Producing Counties, Georgia, 1944

XXVII. Change in Value of Farm Products Sold for 105 Georgia Counties, 1949-59 . . 148 


\section{INTRODUCTION}

The broad aim of this dissertation is to investigate some aspects of agricultural diversification in the Piedmont and parts of the Atlantic Coastal Plain in the state of Georgia. Economic diversification generally evokes a favorable reaction from geographers even when the term is not rigidly defined. The geographer generally agrees that a nation or region with a variety of scurces of income is more viable than one with a single source of income. As far as agriculture is concerned, a mixed farm is assumed to have less risk of fallure than a specialized wheat or cotton farm. Before proceeding with the primary objective of this study it may be instructive to examine the points of view on the subject of diversification commonly taken by the geographer and the farm economist.

The farm economist sees diversification as a situation involving various ilvestock-crop combinations found on the Individual farm units. Such combinations are presumably planned with the hope of achieving maximum utilization of the farmer's resources as well as with the hope of providing protection from risk beyond the control of the farmer, such as fluctuations in prices and ylelds. Thus, diversification is designed to contribute to maximum profits and minimum 
loss on the individual farm. Because the single farm unit is usually the focus of study, one may say that the farm economist takes the micro-approach to diversification.

On the other hand, the geographer most frequently takes the macro-approach. The focus of interest is on the whole area or region rather than on the component units, the Individual farms. Usually, the geographer wants to determine whether the overall output of some area is indicative of its specialization or diversification. This areal or regional diversification, he realizes, may be the result of either subareal or subregional specialization, or the result of a more diffuse type of diversification characteristic of the individual farm. Recognizing the latter fact, the geographer enters the realm of the farm economist. A few studies are cited below that illustrate the geographer's approach.

The wel1-known study of Weaver on crop comblnations in the Middle West exemplifies this point of view. Weaver took the county as his unit of study. He determined whether the county could be classified as a one-crop, twocrop, three-crop, four-crop, five-crop, s1x-crop, or sevencrop area on the basis of the amount of land from which the leading crops in the county were harvested. His final map presentation not only showed the extent of diversification for hundreds of counties in the Middle West but also the 
specific crops involved in the crop combination. ${ }^{1}$ As this article excluded any consideration of livestock, he later published another article that was roughly equivalent to portraying livestock combinations alone. The results of this work challenged widely held notions of a relatively homogeneous Corn Belt.

A more recent study by Stevens and Brandao on the Cacao Coast of Bahia is another example of the macroapproach of the geographer to the subject of diversification. They pointed out that the economy of the areas of traditional cacao monoculture could be improved through Introducing other crops, livestock production, and forestry. Their plan did not suggest that each farm would add these new products, but suggested that certain sub-areas less suited to the traditional cacao production would speclalize in the new products to the extent that their natural and socloeconomic conditions would permit. Hence, the aim here was to improve the economic status of the entire region rather than that of any particular farm. 2

In Prunty's discussion of land occupance in the southeastern United States, he comments on regional agricultural diversification: " . . Instead of general or diversified

IJohn C. Weaver, "Crop-Combination Regions in the Middle West," Geographical Review, XIIV (April, I954), p. 180.

2Rayfred Stevens and Paulo R. Brandao, "Diversir1cation of the Economy of the Cacao Coast of Bahia, Brazil," Economic Geography, XXXVII (July, 1961), pp. 231-53. 
farming on the individual farm, what is emerging throughout the South, Including the cotton regions, is a diversification within each region or area through speclalization of 1ts individual farm components." 3 He further stated In this article that the South had already diversified and was engaged then in Intensifying. Thus Prunty combines the micro-approach with the macro-approach.

In this study, the macro-approach to diversification w1ll be taken. The areal unit selected for study is the county, which because of 1ts small size, espectally in Georgla, should permit a detalled analysis. The 105 counties chosen lie in the Piedmont and Inner Coastal Plain of Georgia. The basic aim then is to determine the relative extent to which the agricultural economy of a county is dominated by one or more products, whether crop or livestock. Two sets of criteria of dominance are used. The first is the income factor as revealed in the value of farm products sold. Census data are avallable for elght categories of products sold and these data are used here. They include the following: (1) field crops other than vegetables, fruit, and nuts; (2) vegetables; (3) fruit and nuts; (4) horticultural specialties; (5) dairy products; (6) poultry products; (7) livestock products other than

3erle C. Prunty, "Land Occupance in the Southeast," Geographical Review, XIII (July, 1952), p. 446. 
poultry and dairy products; and (8) forest products. The first group was broken down further to show cotton and the remainder of sales in this category. This ralsed the total number of categories to nine.

The second criterion is based on the input factor of land, or, more specifically, the acreage of cropland from which certain crops were harvested. The leading seven crops in harvested acreage in addition to cropland used for pasture are used for each county. Cropland used for pasture has been used in the crop acreage analysis because 1t reflects the increasing emphasis on livestock production, which usually indicates a trend toward more diversification for the county as a whole.

It is readily seen that the two criteria supplement and buttress each other. By 1tself, knowledge of the value of farm products sold w1ll not give a complete picture of the relative importance of hay and feed crops in the economy of the county. This is true because, unlive cotton and other fleld crops, the amount of hay and feed crops sold represents only a fraction of the total value of these harvested crops. For instance, in Georgia in 1954, the amount of corn sold was less than one-fifth of the total value of corn harvested. In the same year, less than 10 per cent of the total value of all hay cut was sold. Because the sale of livestock and livestock products 
reflects the consumption of hay and feed crops, such a shortcoming is not so serious as it may first appear.

Since the data on value of rleld crops sold are not broken dow for specific crops, except that figures for cotton have been isolated, it w11l be necessary to rely on acreage from which fleld crops were harvested to estimate the Importance of any one fleld crop to the total value of farm products sold. It is from the value of the various livestock and livestock products sold that their contribution to the diversifled pattern is revealed, rather than from data on cropland acreage. The data on value of farm products sold make it possible to evaluate the place of forestry in the income of the county as well.

The Ginl coefficient of concentration is used to ascertain the relative diversification among the 105 counties chosen here. Th1s statistical device measures the closeness of any given distribution to an equal distribution. In an equal distribution, for example, if the total amount of some variable $1 \mathrm{~s}$ assigned to elght groups, then each group should have one-elghth of the total amount of that variable. Such a condition represents a minimum amount of concentration, or a maximum amount of dispersion, or in this study, diversification. In applying this technique to the first of the criteria of diversification which is based on value of farm products sold from nine categorles, 
each category, such as cotton, or forest products, would represent one-ninth of the total value of farm products sold in an equal distribution. Thus, a cumulative percentage curve with the cumulative percentage of total value of farm products sold on the vertical axis and the percentage of the total number of categories accumulated on the horizontal axis, is a diagonal line rising from zero per cent in the lower left corner of the graph to 100 per cent in the upper right corner of the graph. It is not expected that data for any one of the counties used in this study will conform to such an equal distribution. The value of the Gini coefficient lies in its ability to provide a measure of the closeness approximated by the actual data for a county to an equal distribution. It is a falrly sensitive device with values ranging from zero to one, representing complete diversification, on one hand, and maximum concentration on the other, respectively. Moreover, variance formulas have been worked out for this technique. 4

It should be pointed out at the outset that stat1st1cal Iimitations are inherent in the size variation and contiguity of the counties. These limitations stem mainly from the fact that measured characteristics of one county

${ }^{4}$ Cerald J. Glasser, "Varlance Formulas for the Mean Difference and Coefficlent of Concentration," Journal of the American Statistical Association (September, 1962), pp. 648-54. 
are not independent of those of adjacent counties and size becomes a hidden variable in itself.

The general approach to this study of diversification has been outlined above. At this point, the specific objectives of this thesis are set forth, including the hypotheses that are to be evaluated. Following this, there wil be a short summary of pertinent Ideas and postulates of geographers from whose works suggestions for these hypotheses have arisen.

The first objective is to determine the agricultural diversification of each of the selected 105 Georgia counties for 1939, 1949, and 1959. The criteria of diversification are these: (1) the acreage of cropland used for pasture and specific crops and (2) the value of farm products sold for selected products. Chapter III is devoted to this analysis.

The second objective is. the evaluation of the hypothesis that the trend toward diversification has been weaker in certain "core cotton-producing regions," as delimited by Prunty, than in other areas of the state. The third objective is the evaluation of the hypothesis that there are stages of diversification through which the state, or parts of the state, have passed that can be identified on a basis of changes in land use and source of income. Chapter IV deals with the evaluation of these two hypotheses. 
The fourth objective is the assessment of the relationship of selected socioeconomic variables to the two indices of agricultural diversification. Factor analysis will be used for this task; the results are presented in Chapter V.

Suggestions for the two hypotheses came from an examination of works of several geographers. The first hypothesis, In particular, can be traced to efforts of early geographers to synthesize agricultural and related soc1oeconomic data so as to delimit agricultural regions. O. E. Baker 5 and Derwent Whittlesey ${ }^{6}$ demarcated agricultural regions, such as the Corn Belt and the Cotton Belt. The Cotton Belt, as delineated by Baker and other writers during the 1920's, was an agricultural region with little diversification. To be sure, there was validity in such a regionalization inasmuch as cotton supplied over two-thirds of the total farm income in the majority of southern counties at this time. Acreage in corn equaled that in cotton as early as 1900; however, corn rarely entered commerclal channels. Of special interest here is the observation by Baker, that the trend in cotton production prior to the 1920 's was toward a decrease in production and acreage in

50. E. Baker, "Agrlcultural Reglons of North America," Economic Geography, II (October, 1926), pp. 459-93.

6Derwent Whittlesey, "Major Agricultural Regions of the Earth," Annals of the Assoclation of Amerlcan Geographers, XXVI (september, 1936), pp. 199-240. 
the peripheral cotton-producing areas causing the cotton Belt to contract within 1ts 1920 boundaries.

Working on the same problem, but some thirty years later, Prunty found a further contraction of the cottonproducing reglons within what he called core cotton-producing regions. "The present high density areas [or cotton production] are nodular to the production districts of 1924 and acreage declines have reduced the 1924 districts to residual sectors. . . " he wrote in 1951.7 Both Baker and Prunty felt that these residual districts had inherent advantages and were destined to retain their cotton culture character for years, although Prunty falled to emphasize the role of so1l, climate, and topography as inherent advantages in these areas as had Baker earlier.

With a prevalling trend toward increased diversification in the 1940's, and 1950's when cotton was being displaced by livestock, and especlally in view of the supposed advantages of the core cotton-producing areas, it seems logical to postulate that the diversification trend has been weaker in the core cotton-producing areas than in others.

Prunty noted that increased speclalization on the Individual farm accounted for much of the trend toward

7Merle c. Prunty, Jr., "Recent Quantitative Changes in the Cotton Regions of the Southeastern United States," Economic Qeography, XXVIII (July, 1951), p. 206. 
agricultural diversification in the South as a whole. Supporting his contention, census data reveal that the number of farms specializing in the production of beef cattle, dairy, poultry, and to a lesser extent, fruit and vegetables has grown rapidly since 1930. Therefore, it would appear that diversification cannot be viewed as a static phenomenon, but as a stage in a sequence of events involving a shift from a speclalized cotton economy, on one hand, to specialization in the production of livestock and livestock products, on the other hand. Clearly there is a reason for the second hypothesis stating that there are identifiable stages of diversification, even in view of the fact that the number of mixed or general farms is also rising.

For a more complete understanding of areal variation in agricultural diversification it is necessary to examine certain factors that are known to have influenced changes in agriculture. In fact, the fourth objective of this dissertation is the assessment of the relationship of selected socloeconomic variables to agricultural diversification. Some of these variables tend to vary from region to region, or county to county within the state. Others, no less Important, tend to be relatively more constant in their areal varlation. An example of the latter is the impact of the boll weevil. 
The strong momentum of agricultural diversification In the South, and especially in Georgia, was initiated by the invasion of the boll weevil in the early 1900's. In Georgia, the severest infestation was in the clayey solls of the Pledmont rather than in the sandier soils of the Coastal Pla1n. Thus, the boll weev1l was not only a factor In the decline of cotton production in the Pledmont, but was a partial explanation of the increase in the proportion of the total production of cotton in the state that was grown in the Coastal Plain.

Another example of a variable that fluctuated more with time than through space is the federal programs of acreage allotments. Large acreage reductions in cotton, peanuts, and tobacco were often accompanied by increases in the acreage planted in grain and legumes. This pattern contributed to diversification for the state, despite the fact that the production of the controlled crops often showed little decline due to intensification of production practices.

Another group of socloeconomic fretors also have Influenced trends and areal variations in agriculture. These tend to have considerable spatial and temporal var1ations among counties within the state. One of these is the avallability of capital to the farmer. Wright emphasized the importance of this factor when he pointed out 
that cotton production persisted in some areas because th1s was often the only crop on which the farmer could borrow money to cover the expenses for the following year. 8 In a slightly different vein, Higbee pointed out that the dominance of large solvent landholders in the Black Belt of Alabama who had access to more credit than the small operator was a factor in the conversion of the Black Belt from cotton to pasture and livestock.9 sisk argued the same point a few years earlier.10

The Increased avallability of capital is associated with rising incomes, both on and off the farm, increased productivity of agriculture, and increases in the demand for dalry and poultry products, resulting from both urbanization and industrialization, just to mention the more obvious varlables. Interrelated with these are such socioeconomic factors as changes in the labor-land ratio, the emigration of farm labor, the ethnic composition of the counties, patterns of tenure, and farm mechanization.

- Because most of these socioeconomic variables are interrelated, they can be ordered or grouped in such a

8 Alfred J. Wright, United States and Canada: A Reglonal Geography (2nd ed.; New York: Appleton-CenturyCrofts, Inc., 1956), p. 260.

9Edward Higbee, American Agriculture: Geography, Resources and Conservation (New York: John wiley and Sons, Inc., 1958), p. 330 .

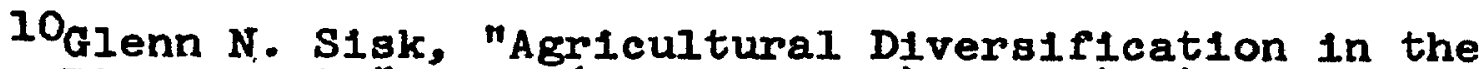
Alabama Black Belt," XXVI (Apr11, 1952), pp. $42-45$. 
manner that a smaller number of variables can express most of the variation of the original number. As indicated earlier, factor analysis will be used for this task. The physical background is of great importance in explaining the distribution of agricultural activities and certainly it is not overlooked in this dissertation. Molsture, temperature, and so1ls are probably the most important of these physical factors. But the distribution of the climatic elements is fairly uniform over the state and there have been no serious climatic fluctuations in the period covered by this study. W1th some qualification this statement applies to the topography. To be sure, the hilly Dahlonega Plateau of the northern Pledmont stands in contrast to the "wire grass" section of the Coastal Plain in Georgia, but these are contrasts of the extremes. Gradations in between are less noticeable. Areal variations in soll are probably of more significance in land use. But these variations in soll types are qualitative and do not lend themselves to quantitative analysis. These physical factors have therefore been excluded from the factor analysis made in Chapter $v$, but are discussed in a general way in the following chapter. 
CHAPTER I

PHYSICAL BACKGROUND

A brief description of the physical geography is given in this chapter. First, the various physlographic regions of the state are presented. The topography, soil, and, where possible, the relationship between the physical factors and land use are included in the discussion of each physlographic region. In the final section of this chapter a brief summary of the climate of the state is presented.

Physiographic conditions and soils

The physlographic divisions that are included in this study are the Pledmont and the Inner Atlantic Coastal Plain. The Coastal Plain adjoins the Pledmont on 1ts landward side (Map I). It occuples more than one-half the state and 1ts sinuous inland boundary passes through Columbus, Macon, and Augusta. It is marked by the Inner boundary of the Tuscaloosa formation (Cretaceous) and the overlapping Barnwell formation (Eocene). ${ }^{I}$ The Coastal

$I_{C}$. Wythe Cooke, Qeology of the Coastal Plain of Georgia, Bulletin of the United States Geological survey No. 941 (Washington: United States Government Printing Office, 1943) and also Physical Geography of Georgia. 


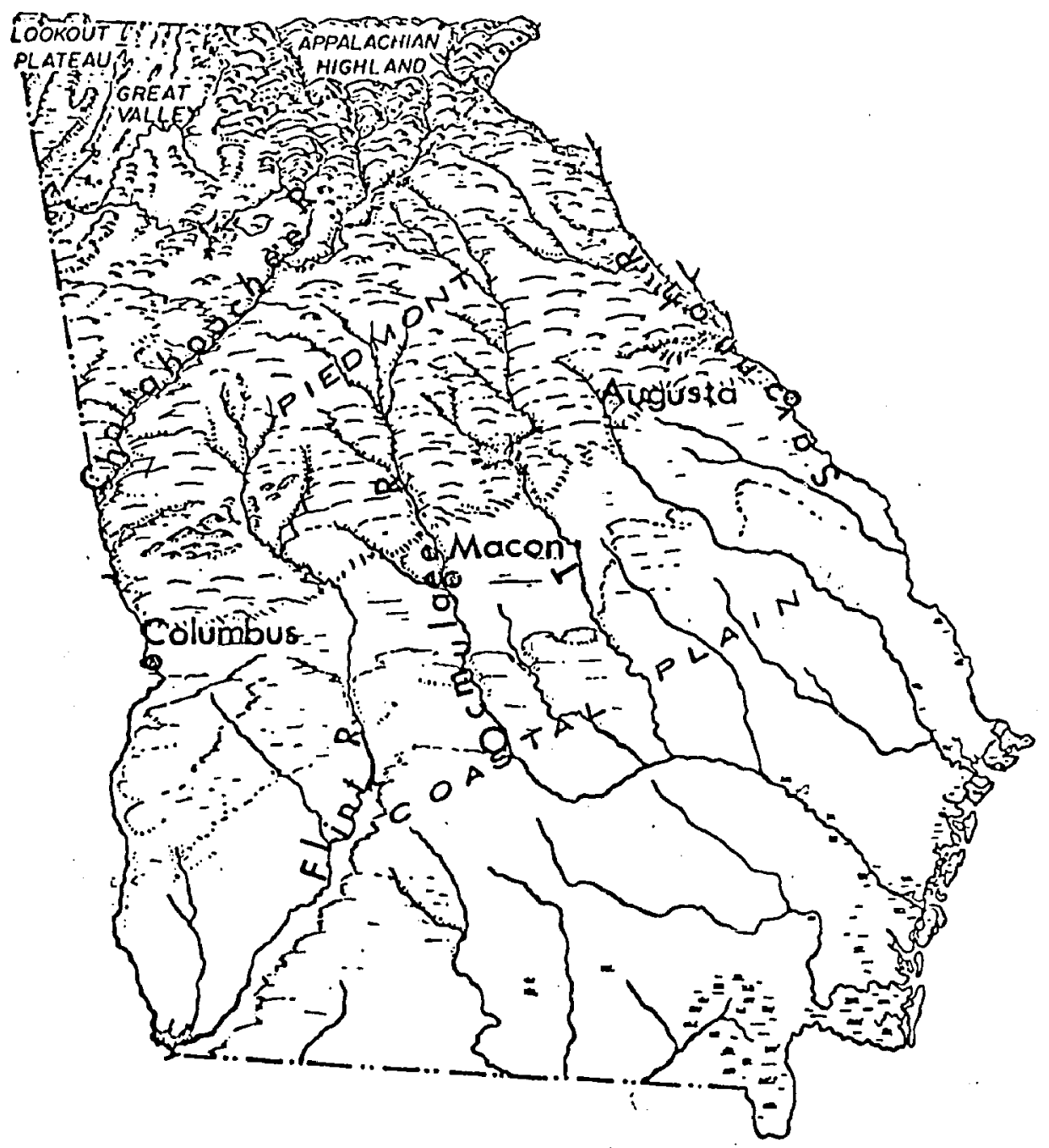

MAP I

PHYSIOGRAPHIC DIAGRAM OF GEORGIA 
Plain is underlain by sediments ranging from Cretaceous to recent Quaternary which crop out in roughly parallel bands, with the oldest resting upon the crystalline rocks of the Pledmont and the youngest at the Atlantic sea coast. Cooke divides the Coastal Plain of Georgia into six topographic regions on a basis of underlying rock and surface character.

The first of these, which Cooke calls the Fall Iine Hills, is an area of rolling hills and valleys corresponding approximately to the outcrop of cretaceous sands and clays and extending across the state from east northeast to west southwest. Streams entering this area from the Pledmont usually have falls or rapids because the sands in the Fall IIne Hills are more easily eroded than the igneous and metamorphic rocks of the Pledmont. The towns--Columbus (Chattahoochee River), Macon (Ocmulgee River), and Augusta (Savannah River) were established at Fall Iine sites partly because of natural advantages inherent in these sites for water power and downstream navigation. The northern part of the Fall Ilne Hills is called the Sand Hills (Map II).2

Georgia Geological Survey Bulletin No. 4 (Atlanta, 1925). Most of the ensuing comments on geology and topography were condensed from varlous portions of both these publications, unless otherwise indicated.

2 John C. Meadows, Modern Georgia (Athens: Un1versity of Georg1a Press, 1954 , pp. 6-7. The map on page 6 of this book was the basis for estimating the southern boundary 


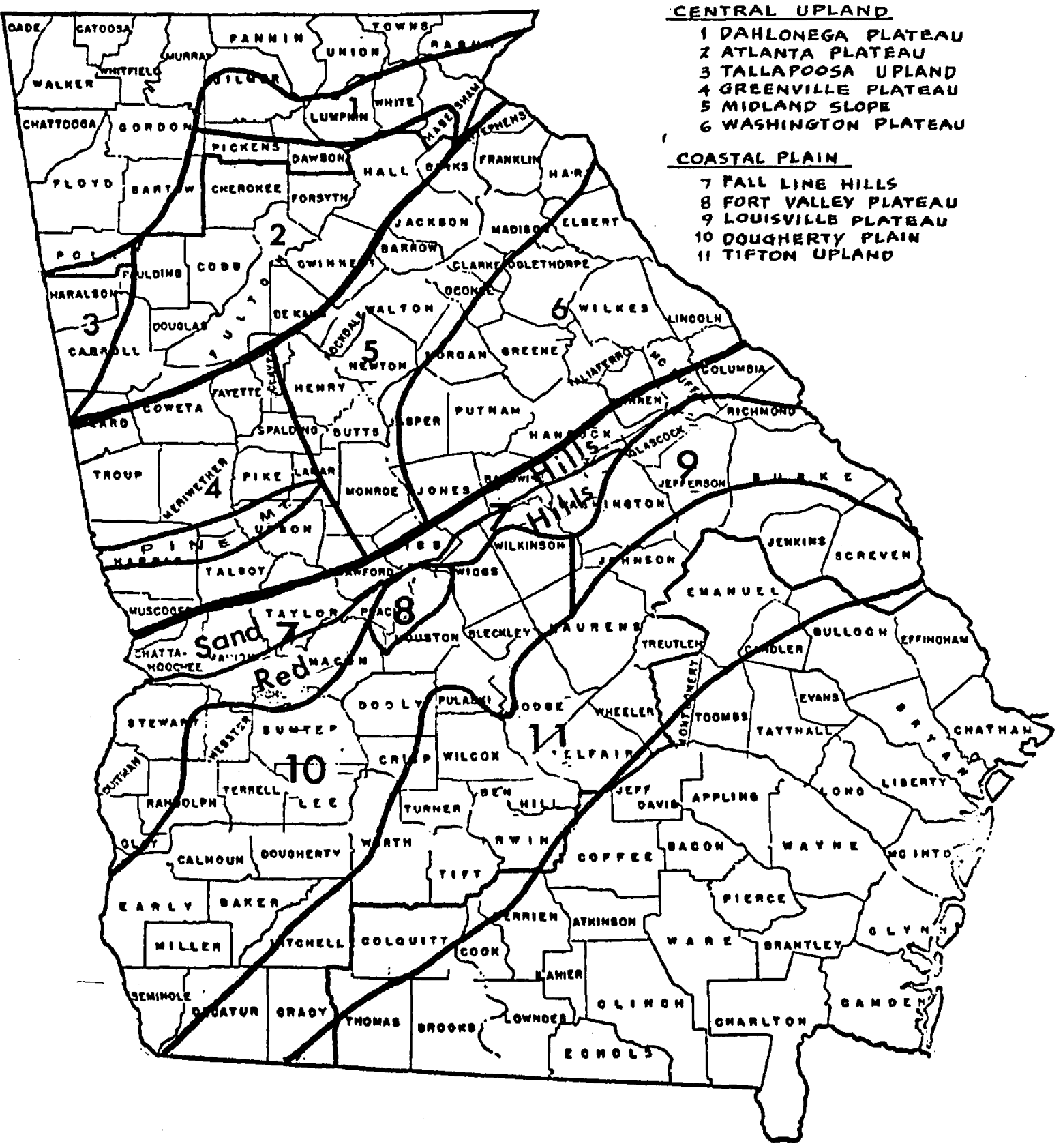

MAP II

PHYSIOGRAPHIC REGIONS OF GEORGIA 
Typical elevations are 400 to 500 feet in the uplands and about 200 to 250 feet in the valley bottoms. The foreated slopes are moderately steep and require intensive erosion prevention practices. The Norfolk-Kershaw solls found here are chlefly sterlie ac1d sands (Map III). Some sandy loams occur in the lowlands. Although harvested cropland is relatively small in comparison with adjacent areas lying to the north and the south, some profitable diversified agriculture is based on cotton, peaches, pecans, and forest products.

Another subregion of the Fall Line Hills, the Red H1lls, lies to the south of the Sand Hills. The Red Hills have lower elevations and have more subdued relief than the Sand Hills. This is apparently related to the higher proportion of clay in the underlying rocks of the Red Hills. In the western section of the Red Hills, extending from Macon to Quitman counties, much of the sandy loam or sandy top soll has been removed by erosion, exposing the heavier clay subsolls beneath. These solls are relatively unproductive. In other parts of the Red Hills, the solls are mainly sandy or clayey loams with red clay subsolls. They are generally thought to be among the most naturally fertile soils in the state. Plantation culture with emphasis

of the Sand H1lis. The other boundaries on Map II are based on a map from Lawrence la Farge et al., Physical Geography of Georgia, Georgia Geological Survey Bulletin No. 42 (At Ianta, 1925). 
A KEY TO SOIL ASSOCIATION AREAS

MAP OF GEORGIA

APPALACHIAN PLATEAU AND VALLEY SOILS:

$\$ 7$ Hartsells - Muskingum Lithosols

1Fi Clarksulle Loami and Planosole

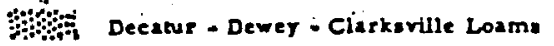

BLUE RTDGE AND INTERMONTANE SOILS:

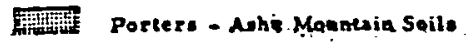

Talladega - Fannit Istermontune Sollo

PISDMONT UPEAND SOILS:

. $\quad \because \because \because$ Cecil - Appling Sandy - Cley Loams

WN Georgeville - Numance (Slate Belt) Loams.

N/, Muskingum - Edgemont (pirie Mt.) Lithosol

COASTAL PLAINS SOILS:

$\approx$ Norlolk - Kershaw Deepp Sande

NIII Norfolk - Ruston Sund! and Loame

Greenville - Magholis Loams

XXX Tifton Loamy Sande

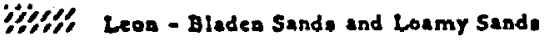

iiiit Coxvlle - Portsmouth - Diaden Hall-Bog Solls

Nlurial Peat and Muck

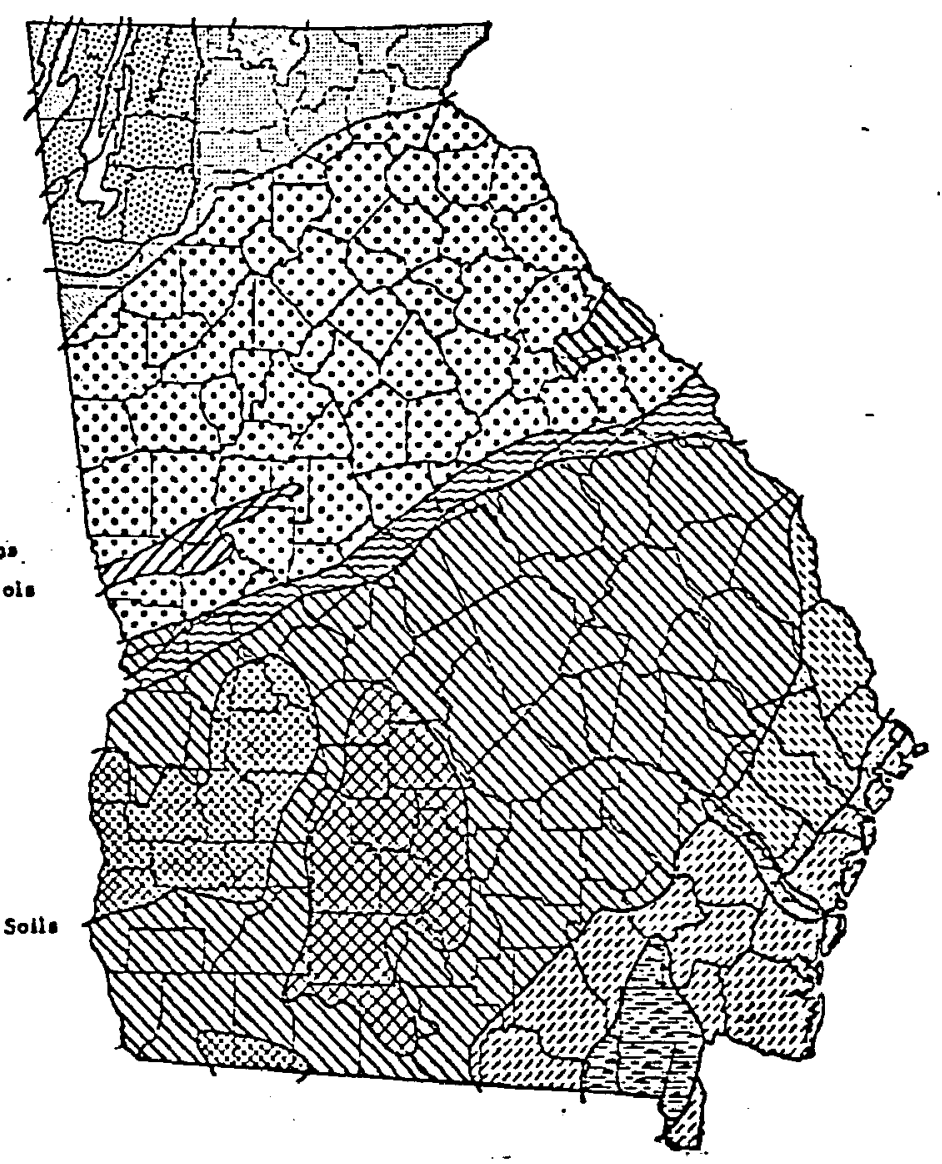

MAP III

GEORGIA SOILS 
on cotton production was so deeply entrenched in the eastern part of this subregion, that only since 1950 have other crops made headway in displacing cotton in the income structure. In the western Red H111s, cotton was I1kew1se a dominant source of income, but here its position was more readily weakened by the boll weevil invasion during the 1920's. The clay so11s in this part of the Red H111s were more susceptible to severe infestation of the insect than the sandier areas farther east. Peanut production 18 important here today.

The second topographic region demarcated by Cooke 18 the Louisvilie Plateau. It lies to the south of the Fall Line Hilis in the eastern part of the state and is underIain by the Barnwell formation. Its outline is determined largely by the areal distribution of red sand and hence $1 t$ is designated as the Red Hills by LeGrand. 3 On a basis of rock type and topography, it actualiy is a continuation of the Fall Iine H1Ils. In Jefferson County, where this plateau is typically dereloped, the altitude ranges from 300 to 500 feet. The northern part of this region is more dissected than the southern section and the former merges imperceptibly with the Fall Ine Hills. Owing to the lack of consolidation of the sands, gullies are common, but erosion

3H. E. IeGrand and A. S. Fucron, Geology and Ground Water Resources of Central-East Georgia, Georgia Geological

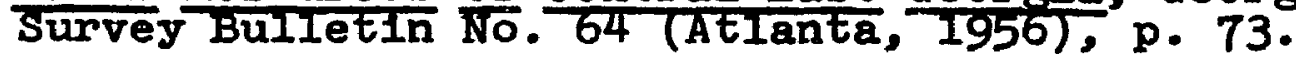


is less severe than in the central section of the Fall Iine Hills. The sandy loams of the plateau are known to be moderately productive. The suitability of the terrain and soll for agriculture in the Loulsville Plateau and in the Red Hills is partly reflected in the proportion of the total area used for cropland. For example, in Burke and Jefferson countles, crops were harvested from 25 and 23 per cent of their total land areas, respectively. These percentages are nearly double those for the state as a whole. As was true for the Red Hills, the legacy of the plantation system-high rates of farm tenancy, relatively low levels of living, minor industrialization, just to mention a few of the problems--persists in the Loulsvilie Plateau today.

The third topographic region, the Fort Valley Plateau, is in Peach County and vicinity (Map II). It is upheld by the red clayey materials or the Barnwell formation. This small area of some 300 square miles averages 400 to 500 feet In altitude. Although the larger part of the plateau is nearly flat, tributaries draining to the Ocmulgee River on the east have cut well back into the plateau and here local relief may exceed 150 feet. Generally, it is dissected only slightly. LeGrand argues that the Fort Valley plateau appears to be a plain of solution, beneath the surface of which ground water has dissolved a layer of limestone, 
probably 0cala.4 A few shallow depressions on the plateau are taken as evidence of the solution action. The red solls derlved from the Barnwell and Ocala residuum have been less leached and eroded than those of the Fall Iine H11ls to the north. In Peach County, the proportion of the total area from which crops were harvested in 1959, was over one-third the total area or more than twice the proportion for the state. This plateau is the nucleus from which the peach growing industry in Georgia developed and It is still the major peach-producing region of the state today. Cropland is used for growing corn, soybeans, and pasture, In addition to peaches, giving rise to a highly diversified economy.

The fourth region of the Atlantic Coastal Plain is the Dougherty Plain (Map II). It owes its low flat terrain to the ready solubility of the Ocala limestone and limy parts of the Flint River formation, most of which has been removed by solution. Numerous saucer-shaped sinks or ponds dot the landscape, especially in Dougherty and Lee counties, apparently due to collapse of cavern roofs in the soluble Iimestone below the surface. Much of the dralnage is subterranean. Elevation ranges from 400 to 500 feet along its landward margin to 100 feet on the south and southwest. As

\footnotetext{
${ }^{4}$. E. LeGrand, Geology and Ground Water Resources of the Macon Area, Georgia Geological survey BuIletin No. 72 . TAtianta, 1962) p. 4.
} 
most of the area is relatively flat, erosion has been only moderate, except for some gullying and sheet erosion in areas of steeper slopes near streams. The AreenvilieMagnolia so118 have developed in this area (Map III). They are described as being moderately to strongly acid in reaction and low in fertility. The Greenvilie solls have brown to reddish brown surface solls and red to deep red or maroon heavy sandy clay subso11s. These red so11s produce the highest yields and best quality of peanuts. This region has one of the highest percentages of total cropland harvested of any major region of the atate. The amooth to slightly rolilng land is well adapted to the use of power machinery.

The fifth region is the Tifton Upland. It occupies a broad band extending across the midale part of the coastal Plain. It is upheld by the relatively resistant sand and gravel of the Hawthorne formation (Miocene) and is aistingulshed form the Loulsville Plateau by 1ts lighter so11s. A low 100-foot scarp separates the Dougherty Plain from the Tifton Upland. The general Impression 18 one of very gently rolling hilis, broad rounded summits and smoothness or configuration. Sinks and ponds are common. Their orlgins have been ascribed to limestone subsurface strata of the Hawthorne formation and to the effects of meteoritic Impact. Erosion has been slight to moderate and few deep gullies, so typlcal of the Fall Line Hills, occur. In the 
southwestern part of this region, centered on Tift and Worth counties, the Tifton and Irvington soils have been developed (Map III). The Tifton solls are considered to be good agricultural lands.5 The surface Tifton so1ls are graylshbrown to gray loamy sands with a yellow to brownish-yellow subsurface sandy loam. The Irvingtion so11s are similar, but have a more compacted subsurface layer than those of the Tifton solls. Both these solls have small pebbly concretions, one-elghth to one-half inch in diameter, in the surface soll, glving rise to the name "wire grass" region. Not only are the Irvington and Tifton solls responsive to fertilization, but they retain good structural qualities with repeated use. Toward the east and in smaller areas of the west of the Tifton Upland, sandier Norfolk and Ruston solls are more widespread.

Because so much of the Tifton Upland is plowable and amenable to cultivation, even using mechanical equipment, farmers have been successful in ralsing the traditional row crops, such as peanuts, tobacco, corn, and cotton. Unlike the Piedmont farmer farther north, farmers in this part of the Coastal Plain have been reluctant to divert land from these row crops to pasture. In a sense, the central part of the Tifton Upland is a transition between the corn-cotton

5011s and Men: Yearbook of Agriculture, 1938, The United States Department of Agriculture (Washington: The United States Government Printing Office, 1938). Th1s yearbook contains information on the fertility, use, and problems of the soils for the major types of so11s. 
economy in the east and the peanut-hog-corn economy in the west. Having this transitional position, this part of the Tifton Upland profits from considerable diversification. Mult1-product combinations of peanuts, tobacco, cotton, corn, hogs, and naval stores are grown on. the indlvidual farms.

The sixth region that Cooke includes in the Coastal Plains is the Coastal Terraces. It will not be discussed here because it is not included in the area studied. The remaining 40 per cent of the state belongs to what La Farge calls Appalachian Georg1a. He divides this district into (1) the crystalline area, including the Central Upland and the Blue Ridge Mountains, and (2) the Paleozolc, embracing the Appalachian RIdge and Valley division and the Appalachian Plateau in the extreme northwest portion of the state. 6 Only the Central Upland is covered in this study.

The Central Upland of La Farge, usually known as just "Piedmont," is subdivided as follows:

I. Pledmont Georgia

1. Dahlonega Plateau

2. Atlanta Plateau

3. Tallapoosa Upland

II. Midland Georgia

1. Midland Slope

2. Washingt on Plateau

3. P1ne Mountain District

4. Greenville Plateau

6Lawrence La Farge, "The Central Upland" and the "Provinces of Appalachian Georgla" in Physical Geography 
The Central Upland is an upland area occupying threeelghths of the state. It is a district of fairly strong relief developed through repeated and long continued erosion of disordered crystalline rocks which have been deeply weathered and disintegrated. The province is underlain by metamorphic and igneous rock. The metamorphic rocks constitute the older 1gneous and sedimentary rock, now metamorphosed, Into which younger Igneous rock have been intruded. Although most of the baslc igneous rocks outcrop, the solls have tended to be relatively dark in color.

The Piedmont region is separated from Midland Georgia partly on a basis of relief, elevation, and drainage (Map II). The main stream, the Chattahoochee, has produced considerable dissection in its vicinity. Piedmont Georgia also has conslderable relief as a result of scattered monadnocks 7 which rise 100 to 1000 feet above the general level. These monadnocks are more numerous in the Atlanta Plateau subdivision. The famous Stone Mountain is a boss of granite that rises 650 feet above the surrounding landscape. The Tallapoosa Plateau may be considered as an extension of the Atlanta Plateau, but it is considerably more dissected

of Georgla, Georgia Geological Survey Bulletin No. 42 (Atlanta, 1925). The comments on solls and topography were taken from this work unless otherwise indicated.

7 Today some geomorphologists would prefer using residual hills or hills instead of the term monadnock because the latter term Implies evolution of the landscape to the stage of peneplanation. 
and has fewer monadnocks. Elevation and rellef are greatest In that subregion of the Pledmont lmown as the Dahlonega Plateau. Only a small fraction of this latter subregion is covered in this dissertation.

Midland Georgia lies to the south of the Pledmont. Relief diversity is more restricted than in the piedmont and monadnocks are nearly nonexistent. The main rivers, though deep, are narrow and the upland character of the region is exhibited even when one is close to these streams. The Greenvilie Plateau in the west varies in altitude between 500 and 900 feet and it slopes toward the south. The higher surface of this subregion is generally flat and uniform except for some dissection near the Filnt and Chattahoochee rivers. The Pine Mountain subregion divides the Greenvilie Plateau 1nto two parts. These "mountains" have sinuous bold ridges rising up to 500 feet over the plateau. Elevations reach 1000 feet or more. The sides of the ridges are steep and rough and the gorges cut through them are wild and pleturesque. 8 Belng mainly wooded, the Pine Mountains have little land under plow. The Washington Plateau subregion of Midland Georgia has been described as a broadly rolling area on whose divides level or nearly level land extends for miles. Elevations range from 500 to 800 feet between the Coastal Plain on the south and the

$$
8_{\text {Ib1d., p. } 62 .}
$$


Midland Slope on the northern margin. Only near the trunk streams is dissection important. Graves Mountain in Incoln County is about the only conspicuous monadnock. The Midland Slope differs from the Washington Plateau in being higher and having more but less noticeable hills. The solls of the Central Upland, including the Pledmont and Midland Georgia, are mainly the red lands orlginating from decomposed granite, quartzite, schist, and slate. Most of the solls in the region belong to the cecll-Appling association (Map III). The Cecil soils, derived from granite, predominate throughout the area. They are characterized by elther gray sandy loam or red clay loamy surface solls underlain by stiff red clay subsolls. Although cotton is grown on the cec1l clay and clay loams, the most extensively used cotton soll in the cecil series is the cecil sandy loam. It requires liberal fertilization to be made productive. The Appling solls are similarly grayish in the upper soll horlzon, but they have a more friable subso11. The more clayey solls of the Appling and Cecil serles were once prized for growing cotton. With the onslaught of the boll weevil, however, relatively heavy infestations led to shifts to regions of lighter solls. Another major obstacle to farming has been soll erosion. As a result of plowing slopes too steep and erodible for cultivation, much farm land has been devastated and taken over by pine forests. 
Up to 80 per cent of the top 8011 has been removed in certain areas because of gully and sheet erosion. The amount of cropland from whlch clean tilled crops are now harvested in the Central Upland is comparatively small when compared with that in the Coastal Plain. Although one of the major cotton growing regions is still in the Midland subregion, cotton ylelds are kept hIgh only at the expense of heavy fertilization. Moreover, this region has devoted larger acreages to growing legumes, hay, and pasture than the Coastal Plain in recent years.

It has been shown that the solls and topography have influenced agriculture both directly and indirectiy. The direct influence can be seen in the case where the Pine Mountains, and to a more limited degree, the Sand Hills, had little land under cultivation in relationship to other parts of the state, such as the Dougherty Plain and Tifton Upland. Furthermore, only limited mechanization was possible in such areas. An Indirect effect of the soll texture was seen in the greater boll weevil damage to the cotton plant in clayey areas. The heavier solls promote later maturity, larger vegetative growth, and hence, greater boll weev1l damage. This factor, in turn, led to a shift in the cotton growing regions to areas of lighter textured solls outside of the Pledmont and the development of some diversifled farming in areas from which cotton-growing had been shifted. Unfortunately, the specific effects of soil and 
terrain cannot be assessed on a county basis because these natural regions may elther overlap county boundarles or Include only a small portion of any one county. Since the county was the basic unit for this study and since fleld work was limited, it was felt that additional effort could not be spent to assess the importance of these physical factors by more elaborate statistical techniques.

\section{Climate}

Because of the relatively small size of the area studied in this thesis, the areal distribution of climate is more or less uniform. In fact, seasonal varlations in climate are greater than those varlations encountered in moving between latitudinal extremes of the state. Temperature, molsture, and other elements of atmospheric conditions In the southernmost parts of the state are not much different from those of the northern margin. Th1s is true for a number of reasons, chief among which is the fact that the latitudinal extent of four degrees for the entire state, and less than that for the area under investigation, is quite small. Second, no part of the state is significantly farther removed from the Atlantic Ocean and Gulf of Mexico than any other. The relatively high rainfall near the Gulf, the source of moisture for most of the Southeast, is more than offset by the increase in rainfall due to higher elevations in the Appalachians. The third reason, and one 
related to the foregoing statement, is that altitudinal differences are not extreme. The entire area of this study slopes gently southeastward from an elevation of 1800 feet to sea level.

The climate of the entire state falls under Koppen's Humld Mesothermal Subtropical type. The average temperature for the coldest month ranges from $50^{\circ} \mathrm{F}$. In the extreme southern section to $40^{\circ} \mathrm{F}$. along the northern margin of the pledmont. The range for the warmest month over this area, $80^{\circ} \mathrm{F}$. to $83^{\circ} \mathrm{F}$. , is even smaller. Both the areal and seasonal distributions of precipitation are fairly uniform. Rainfall in the northern Pledmont exceeds the average annual total of about 50 inches for the state as a whole by some 10 inches. The extreme southern margin of the state, being influenced by those summer rain-making conditions near the Gulf of Mexico, gets over 54 inches of precipitation.

Although there is no pronounced dry season, two perlods of the year are generally drier than the remalnder of the year. The primary minimum occurs in SeptemberOctober, when the rainfall for these two months may fall as low as four inches. This drought is beneficlal to the harvesting of cotton and the drying of peanuts, but harmful to many perennial grasses and trees. The second minimum occurs in May-June, at a time that may be critical to maturing plants. Irrigation becomes profitable and 
necessary, in many cases in order to maintain good ylelds. In 1959, nearly 34,000 acres of farm land was 1rrigated, or less than one per cent of the total cropland harvested of nearly seven million acres.9 Tift, Coffee, Tattnall, Colquitt, and Decatur counties led all others in irrigated farm 1and. Despite the fact that the winter rain is of the gentle fromtal type, it has destructive erosive power on unprotected land. Much of the sheet erosion can be traced to these winter rains.

In concluding this section on climate, it may be pointed out that climatic variations are not the key to understanding county to county varlations in land use. It is true that the cooler temperatures in the northern third of the state are more conduclve to producing wheat, barley, and other small grains than the southern third. Yet wheat can be produced in the southern third of the state, and for that matter, climate does not prevent the farmer in the northern third of the state from growing cotton, peanuts or tobacco. The few days difference in the length of growing season or difference in wind direction does not make climate a cruclal problem for most of the crops grown in the state.

9U. S. Bureau of the Census, United States Census of Agriculture: 1959, I, Pt. 28, p. 3. 
CHAPTER II

SOCIOECONOMIC BACKAROUND

In this chapter some general soc1oeconomic data on Georg1a will be presented. Such information will serve as a useful background for understanding agricultural diversiflcation, and even for assessing the impact of diversification on the area selected for investigation here. The state economic areas (hereafter referred to as SEA's) of Bogue and Beale facliltate a description of the type which follows because their economic areas are larger than and not so numerous as the smaller county units. 1 Furthermore, the regions have some socloeconomic homogenelty (Map IV). Only SEA's 3 through $7 \mathrm{~b}$ are included in this study. Other areas of the state were excluded because they lie outside of what was described by Baker as the cotton Belt.

State economic areas of the Pledmont

In what was called the Central Upland of Georgia in the last chapter, but more commonly called the Pledmont,

${ }^{1}$ Donald J. Bogue and Calvin I. Beale, Economic Areas of the United States (New York: The Free Press of Glencoe, Inc., 1961). Most of the description that follors was taken from this work. The agricultural data for 1959 were 


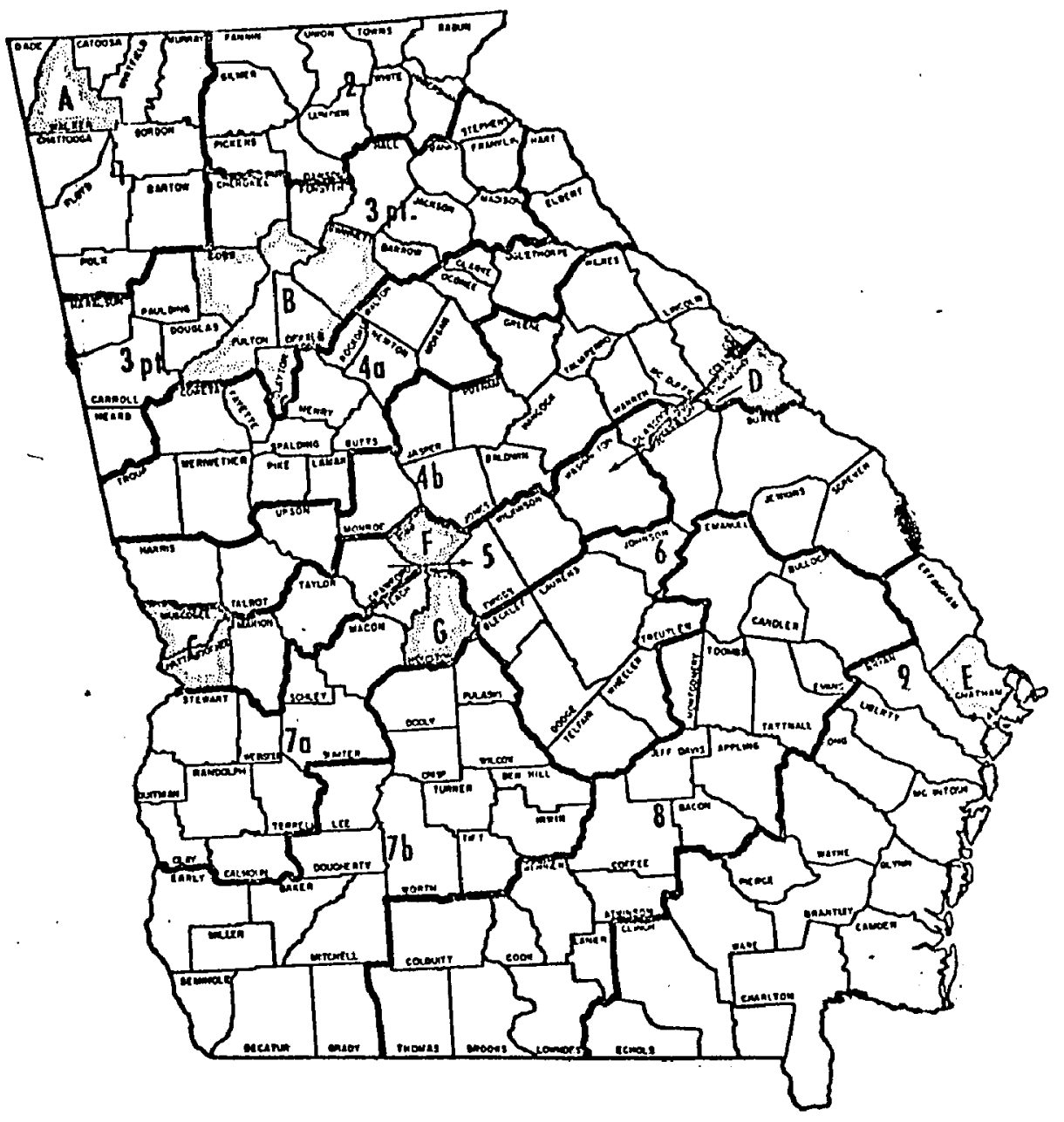

MAP IV

STATE ECONOMIC AREAS, GEORGIA, 1960 
Bogue and Beale demarcated four SEA's: 3, 4a, 4b, and B. The latter area is the Atlanta metropolitan economic area or standard metropolitan statist1cal area. These four state economic areas are a part of a larger region that extends Into the Pledmont of Alabama and South Carolina. For this larger region, especially for Georgia, manufacturing had surpassed agriculture as a source of wealth and income by 1950. Both in 1950 and in 1960, manufacturing accounted for at least three-tenths of the total labor force in every one of the SEA's except in Atlanta, where because of its large size, the proportion of the labor force engaged in manufacturing had suffered at the expense of tertiary activities. Moreover, in all four of the SEA's mentioned above, the percentage of the labor force employed in manufacturing exceeded that in agriculture. Such proportions of the population employed in manufacturing presuppose some degree of urbanization. When an average was taken of the percentage of the total population classifled as urban for all counties in each of the three nonmetropolitan SEA's, for 1960, It was found that SEA $4 \mathrm{a}$ had an average of 30 per cent of Its population classified as urban. It was followed by SEA 4b and SEA 3 having 19 and 17 per cent urban, respectively. For the four areas, however, there were 20 counties

taken from the United States Census of Agriculture, 1959. The data on population came rom the United states census of Population, 1950 and 1960. Other sources are Indicated. 
with no part of their population classed as urban (Map V). A lengthier discussion on the clties of these areas follows. The dominant city of the region is Atlanta. The metropolitan area has one mililon inhabitants. It is the political center of Fulton County and the state, a financial center (reglonal headquarters of the S1xth Federal Reserve District), and a trade and communications center. As a manufacturing center, it far overshadows any other town in Georgia. Its industries include textlles, foods, alrcraft, automoblle assemblying, and brewing. In 1962, 86,000 persons were employed in manufacturing. ${ }^{2}$ Employment by major Industry group is shown in Table 1.

The dominance of the Atlanta metropolitan complex in the Georgia Pledmont is seen in the fact that the next largest city, Athens in Clarke County, had a population of only 33,000 in 1960. Athens is the seat of the state university and in addition produces foods, textiles, and electrical equipment. La Grange (population 23,632 in 1960), In Troup County, had 6,566 persons employed in the manufacture of rugs, canvas, bagging, and other goods. West Polnt, also in Troup County, is a part of a textileproducing complex which includes Lanett across the Alabama line. Griffin in Spalding County has a population of 21,735 and includes among 1ts manufactures corduroy, velvet,

\footnotetext{
2U. S. Bureau of Labor Statistics, Employment and Earnings, IX (July, 1962), p. 24.
} 
TABIE 1

EMPLOYMENT IN NONAGRICULTURAL ACTIVITY

BY INDUSTRY, ATLANTA, 1962

Industry Group

Number of Employees

(000's)

Contract construction

23.4

Manufacturing

86.6

Transportation and public utilities

37.0

Trade

99.9

Finance

28.5

Service

53.9

Government

54.6

Total

383.9

Source: Bureau of Labor Statistics, Employments and Earnings, IX (July, 1962), p. 24.

broadcloth, towels, hoslery, and underwear. Galnesville, In Hall County at the foot of the Blue Ridge Mountains, is In the heart of the poultry ralsing section of the state. It is the largest commercial town (population in 1960, 16,523) in northeast Georgia. Carrolton in Carroll County and Milledgeville in Baldwin County are other towns with more than 10,000 inhabitants located in the Pledmont. The latter thrives on the presence of several state schools and the state mental hospital. 
There is a relationship between urbanization and many facets of agriculture. For example, the Pearsonian coefficlent of correlation between the per cent urban and the value of bulldings and farms was .58. In general, the urbanized counties had relatively high levels of living of farm famliles (Maps $V$ and VI). The role of the urban center as a market, source of capital, and absorber of surplus rural labor gives it, the urban center, definite slgnificance in agricultural developments. The development of dairying in Putnam, Newton, and Monroe counties is doubtless related to the demand for fresh milk and butter In the Atlanta and Macon urban centers. The ability of these urban centers to provide off farm employment for surplus rural labor is partly reflected in the shift from labor intensive cotton production to labor extensive grain and pasture -raising. The increase in these activities has paralleled the growth of the poultry and beef cattle industries. The role of urbanization in agricultural diversification will be lllustrated further in Chapter III.

The distribution of nonwhites has had a profound influence on agricultural developments, and in turn, it has shown the effects of agricultural developments. For example, counties with large percentages of their population classified as nonwhite tend to have high rates of farm tenancy. This situation is a legacy of the cotton plantation system. Most of the leading cotton-growing counties have 


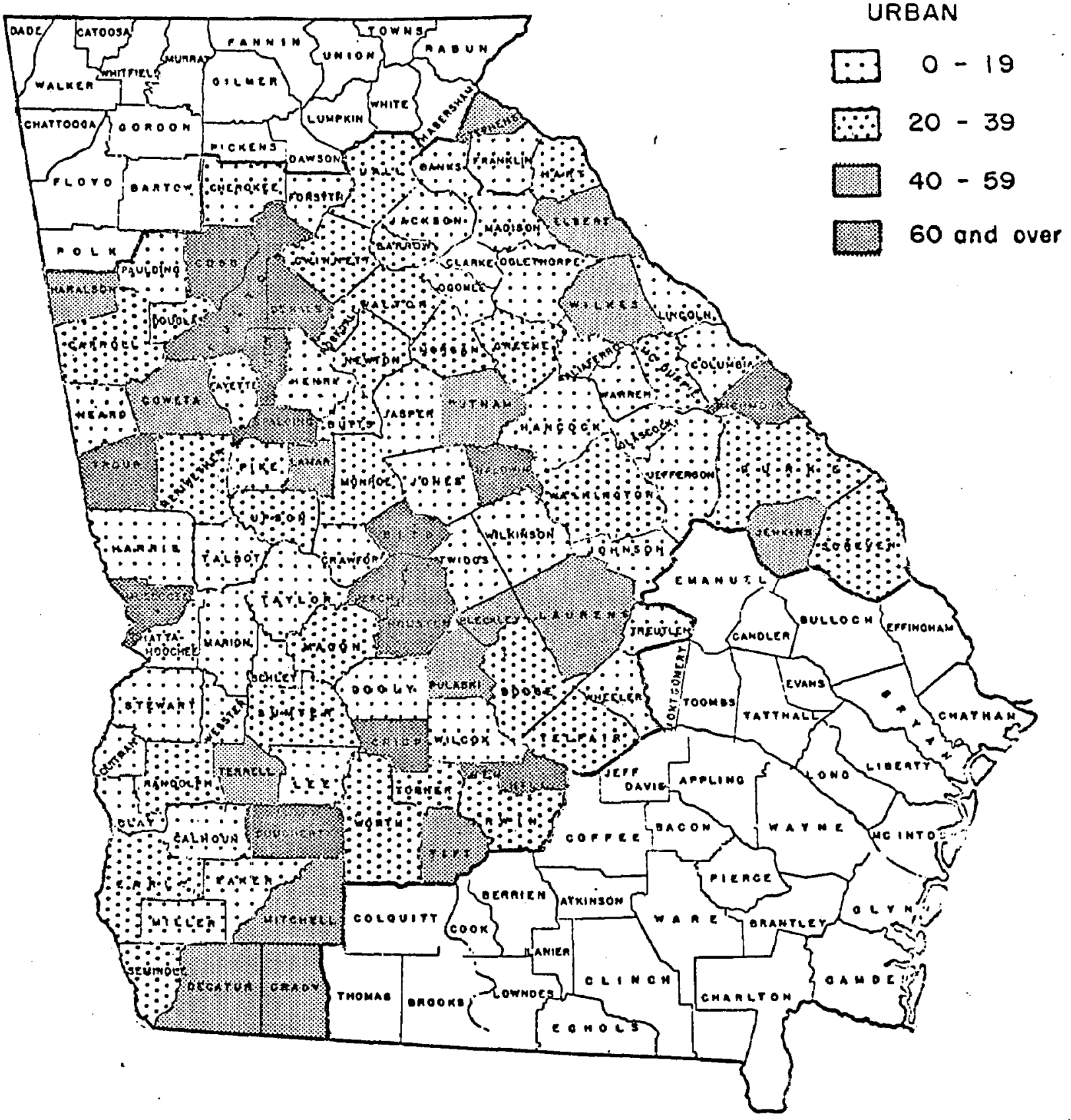

MAP V

PERCENTAGE OF TOTAL POPULATION URBAN FOR 105 GEORGIA COUNTIES, 1960 
Level of Living Index

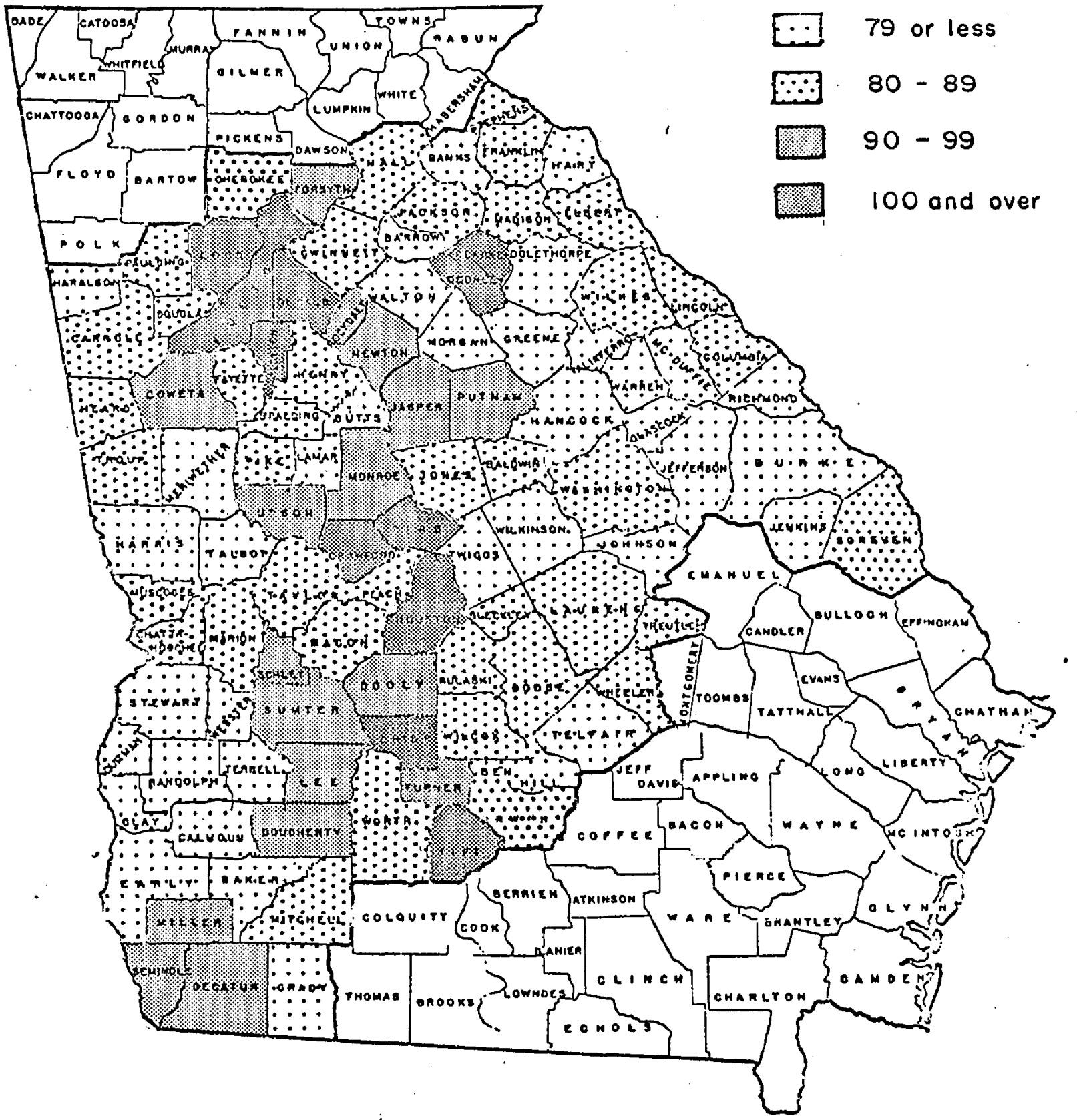

MAP VI

LEVEL OF LIVING OF FARM FAMILIES FOR 105 GEORGIA COUNTIES, 1960 
diversifled their sources of income somewhat more slowly than the remainder of the state. That part of the Pledmont lying in SEA 's $4 a$ and $4 b$ was an area of high nonwhite concentration before 1940, but today, emigration, urban1zation, and other factors have led to shifts in the areas of greatest nonwhite concentrations to the Coastal Plain and, in general, a reduction of this concentration in the Pledmont. In 1950, SEA's 3, 4a, and 4b had 12, 34, and 50 per cent of their population in the nonwhite category, respectively. Having changed but little by 1960, these percentages for SEA's 3, 4a, and $4 b$ were 15, 30, and 47 , respectively. OnIy in SEA 4b was the percentage of nonwhites significantiy greater than that for the entire state.

In 1920, the Georgia Pledmont was one of the leading cotton-growing regions of the state and of the South. Then came the rull impact of the boll weevil, and competition from newer cotton producing areas and manmade fabr1cs. The effects of all these developments included drastic reductions in the area planted to cotton and fewer cotton farms. The total cotton acreage fell from 570,000 In 1919 to 76,000 acres in 1954 in SEA 3. Cotton flelds once occupled 600,000 acres in SEA 4b, but in 1954, this $f$ f1gure was down to 60,000 acres. SEA $4 a$ has clung more to the old cotton tradition than elther 1ts northern or southern nelghbor in the Pledmont, but there have been reductions here too. SEA $4 a$ harvested cotton from 153,000 
acres in 1954, or 17 per cent of the harvested acreage in 1919. In addition, 72 per cent of 1ts commercial farms were cotton farms, compared with 38 and 56 per cent in SEA 3 and SEA 4b, respect1vely. In fact, this region showed more resistance to modernizing trends in agriculture than other parts of the state, up to 1950.

State economic area 5

Adjacent to, but south of the Pledmont lies the Fall Iine Sand Hill region, or SEA 5. The continuity of SEA 5 is broken by three metropolitan economic areas: SEA C (Columbus), SEA D (Augusta), and SEA F (Macon). Outside of the three towns the area remains rural. In 1950, in the rural nonmetropolitan section, seven per cent of the population was urban; almost one-half of the labor force was employed in agriculture compared with about onefourth in the Pledmont. In 1960, these percentages were essentially the same as for 1950, except that the proportion employed in agriculture had fallen to one-fifth in SEA 5. Both in 1960 and in 1950, slightly more than onehalf of the population was nonwhite. Cotton farms were st111 more numerous than any other type, but livestock and livestock products were the largest source of income in 1954. Legumes, such as soybeans and cowpeas, and peaches made for considerable diversification in the 1940-1960 period. BIbb and Crawford counties formed a core around 
which diversifled farming had developed by 1939. A more detalled discussion follows in Chapter III.

In many respects SEA 5 and the three metropolitan economic areas are unique as a region, while in others, this region is transitional between the pledmont and the remalnder of the Coastal Plain. This was especially true for 1950 and 1960. The uniqueness of this entire Fall Line Sand Hills region lies in the three fall line cities, the relatively small percentage of the total land area in farms, and the large percentage of rural population outside the metropolitan countles. See Map V for the distribution of the urban population. Just under two-thirds of the land area is in farms in comparison with over 80 per cent in the area to the south and about 75 per cent in the Pledmont. In 1950, the nonmetropolitan part of this region was a transition between the Pledmont and the other parts of the Coastal Plain, with respect to the nonwhite proportion of the population, the rate of farm tenancy, and the percentage of persons employed in manufacturing. At this time, the nonwhite proportion of the population was 54 per cent, more than the average for the Pledmont but less than the average percentage of nonwhites in the three state economic areas lying to the south. By 1960, however, the proportion of nonwhites in the total population exceeded that of any other economic area. In the Fall Iine Sand Hills, SEA 5, 53 per cent of the farmers were tenants in 1950. Th1s percentage 
was more than that for the Pledmont, but less than the Coastal Plain average. By 1960, however, the percentage of tenancy was down to 32 per cent, but the transitional position of SEA 5 was still evident in this respect. In this region, both in 1950 and in 1960, one-fifth of the working force was employed in manufacturing; this figure was below that for the Pledmont but above that of the Coastal Plain.

The three towns, Augusta (RIchmond County), Macon ( $\mathrm{B} 1 \mathrm{bb}$ County), and Columbus (Chattahoochee and Muscogee counties), were established early in colonial times because of natural advantages inherent in the fall zone location for water power and downstream navigation. Recent impetus to growth has come from the establishment and growth of defense installations. Augusta (110,870 population, 1960) manufactures goods from cotton, clay, and lumber. It is now profiting from the industrial activity connected with the construction and operation of the nearby Savannah River Atomic Energy Plant. In the vicinity is the Camp Gordon army base. Macon (114,161, 1960 population) is a one time capital of the state. It manufactures textiles, clothing, clay, wood, and paper products. It is a major peach market and rallroad center. The major recent development in the Macon area was the establishment of the Warner Robins Air Material Area in nearby Houston County. Houston County was included in the Macon metropolitan economic area 
In 1960. Columbus (171,634, population in 1960) is one of the oldest textile centers in the state, owing much of Its early prominence to water power from the Chattahoochee River, the avallability of cotton, and cheap means of transportation downstream from the fall zone. Nearby is Fort Benning occupying a 300 square mile tract with more than 25,000 persons in 1960. Columbus 1s the fastest growing of the three Fall Line cities. Of all three cities, Macon appears to have had the greatest influence on agricultural conditions in the environs of the city. This has been especlally true with respect to the level of living of farm familles and diversification of land use as well as source of income on the farms. However, it is difficult to 1solate and assess this urban influence because so many other factors could have bearing on the situation.

State economic areas of the Atlantic Coastal Plain

Bogue and Beale designated SEA 6 as the Georgla Upper Coastal PIain (Map IV). In many respects this is one of the least economically developed regions of the state. Even as late as 1960, it had limited urbanization, low family incomes, low levels of living of farm families and a high rate of emigration. Between 1950 and 1960, the population declined by one-tenth. This was mainly the result of farm (both white and nonwhite) emigration in the wake of cutbacks in cotton acreages and increased mechanization. The nonwhite proportion of the population in 
1960 ( 43 per cent) was almost the same as that ten years earlier. Although the urban percentage of the population rose from 17 to 25 between 1950 and 1960, several counties had no urban population in the latter year. Even the IImited urban population in SEA 6 was the result of residence in small towns. The largest city, Dublin, had only 13,814 Inhabitants in 1960; no other town had more than 10,000. This slight urbanization was probably assoclated with low family incomes. Not one county had a median family income as large as that for the state as a whole. The level of living of farm operators, shown in Map VI was decidedly below the rest of the Coastal Plain, except for the western tier of counties in SEA $7 \mathrm{a}$.

The economic lag of SEA 6 seems to be related to the dominancy of cotton. On a basis of 1954 data Bogue and Beale stated that this region was the only SEA where cotton, once holding a complete sway, was st1ll the dominant crop. In this same year cash recelpts from cotton exceeded the comblned recelpts of other farm products. The 1954 cotton acreage of 188,144 represented 40 per cent of the 1919 acreage. SEA $7 \mathrm{~b}$ was the nearest competitor for this distinction; 1ts cotton acreage in 1954 was 28 per cent of the 1919 figure. Iike SEA 4a, SEA 6 has been one area where the position of cotton has been maintained. Corn is important in the land usage, but not significant as a source of income. Legumes, grain, and livestock production 
have contributed to the incipient diversification. In general, however, agricultural diversification, especially of income, has been relatively weak in SEA 6 .

In many respects, SEA's $7 \hat{\mathrm{a}}$ and $7 \mathrm{~b}$ could be regarded as a single region. The terrain is low, flat, and undissected except for the northwestern area near Stewart and Webster counties. Both are predominantly rural; only about one-fourth of the population resided in urban places, in 1960. Thus, employment in manufacturing and other nonfarm activity was limited. In 1960, farming was apparently a profitable enterprise. The level of living of farm families and the value of products sold from their farms were high when compared with the state as a whole and especially with SEA 6. This prosperity in SEA's $7 \mathrm{a}$ and $7 \mathrm{~b}$ was partly due to the diversification of the individual farm.

Nevertheless, there are several differences between SEA $7 \mathrm{a}$ and SEA 7b; such differences warrant discussing the regions separately.

One of the big differences between SEA $7 \mathrm{a}$ and SEA $7 \mathrm{~b}$ is that the former had a higher rate of population growth between 1950 and 1960. Between 1950 and 1960 the population In SEA 7 a Increased 26 per cent, compared to three per cent in SEA $7 \mathrm{~b}$. If Albany had not been removed from SEA $7 \mathrm{~b}$ because of 1ts new metropolitan status in 1960, the rates of growth would have been comparable. The major towns gained population in this decade. In 1960, the number of 
Inhabitants of Americus rose 18 per cent to 13,472. Fort Valley gained 22 per cent to hit the 8,000 mark. Warner Robins, already discussed in the Sand Hills of the Fall Iine since it is now a part of the Macon economic area, increased in population by 133 per cent. Th1s high rate can be attributed to the growing military signiflcance of a town specializing in repalring military aircraft. The small number and size of urban centers, however, did not promote increased employment in nonfarm activity. In 1960, slightly less than one-fifth of the population was employed in manufacturing.

This growth of population in SEA $7 a$ was accomplished in face of heavy out-migration of nonwhites in the same decade. The nonwhite proportion of the population fell from 64 to 44 per cent during this period. Associated with this nonwhite percentage of the population was a high rate of farm tenancy. Forty per cent of the farmers in SEA 7a were tenants in 1960. This was the highest rate of tenancy for any of the economic areas.

The easternmost section of SEA $7 a$, in Peach and nearby counties, was one of the most diversified agricultural areas of the state in 1960. The death blow to the dominance of cotton followed the boll weev1l in the 1920's; in 1954 the acraage from which cotton was harvested was 15 per cent or the 1919 area. Th1s is a low flgure when compared with that of 40 per cent in SEA 6 . Peaches, pecans, and legumes 
were the Invading crops. Now peanuts, hogs, and cotton are all important to the income of these farmers.

In general, SEA To is the most economically advanced region of the Coastal Plain. The urban proportion of the population (27 per cent) was higher than for any other region, even when Albany was excluded. Albany had become a separate metropolitan economic area in 1960 with a population of 55,890. Its 1950-60 rate of growth of 80 per cent was accompanied by a substantial increase in employment in manufacturing and white collar jobs. The nearby Turner Alr Force Base contributed to this growth. Tifton (Tift County), Bainbridge (Decatur County), and Cordele (Crisp County) were close to the 10,000 mark in population. Urbanization was reflected in the opportunities for nonfarm employment. One-half of the counties in SEA $7 \mathrm{~b}$, compared with only two counties in SEA $7 a$, had over 50 farmers working off farm more than 100 days in 1960.

The prosperity of SEA 7b was especlally evident in agriculture. In regard to the level of living (Map VI) and the percentage of farms having tractors (Map VII), SEA $7 \mathrm{~b}$ ranked among the highest in the state. The ratio or tenants to all farmers and the percentage of nonwhites were significantly lower in SEA To than in SEA 7a. In 1960, the nonwhite proportion of the population and the rate of farm tenancy were just under one-third. The average sized farm of 153 acres was less than that for the state as a 


\section{PERCENTAGES}

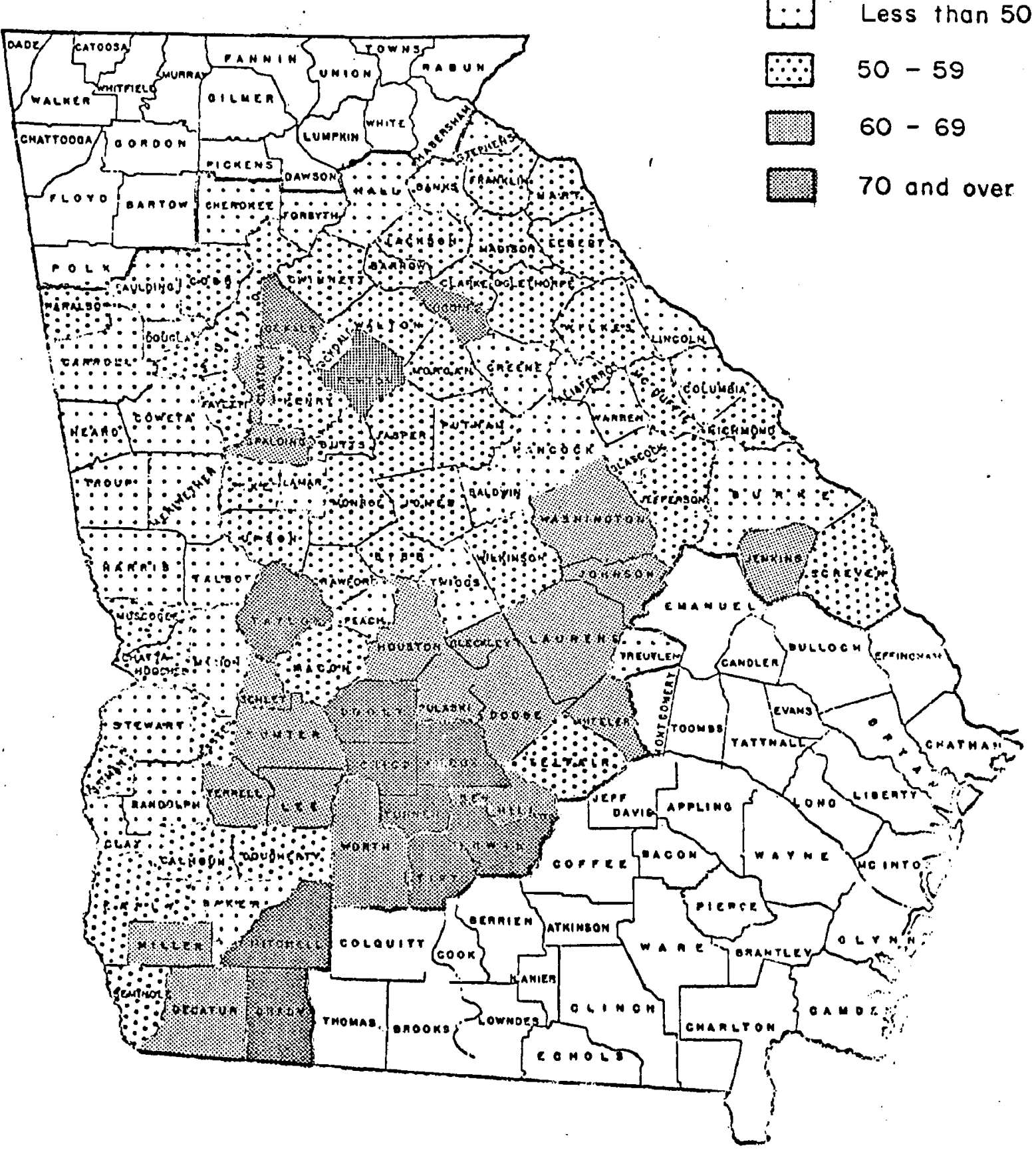

MAP VII

PERCENTAGE OF FARMS HAVING TRACTORS FOR

105 GEORGIA COUNTIES, 1959 
whole, but SEA 7b had a larger proportion of 1ts farms exceeding 500 acres than did the state.

Some of this welfare in the agricultural sector could be attributed to agricultural diversification. Tobacco was important in the southeast; watermelons and cantaloupes became a major source of income in and around Crisp County. Vegetables were a major source of cash recelpts in Grady county and vicinity. In addition to these, the traditional row crops--corn, cotton, and peanuts--continued to be important in the income picture. SEA $7 \mathrm{~b}$ was second to SEA 6 as a cotton growing region and in the extent to which cotton cultivation persisted since the 1920's. With such varied sources of incomes from crops, farmers have reluctantly shifted to livestock production except for hogs. The hog production fitted in well with the peanut economy in the early days of peanut production, when peanuts were left unharvested to be "hogged off" by swine. The number of general farms in SEA $7 \mathrm{~b}$ was one-f1fth of the total number of farms in that economic area. ${ }^{2}$ No other region of the state had such a high proportion of general farms. The main conclusion that emerges from this chapter Is that there are some basic differences between the Pledmont and the Atlantic Coastal Plaln. The Pledmont in the

2The Census Bureau defines a general farm as one where the value of products sold from any one source represented less than 50 per cent of all farm products sold. 
north has had much of its economic development sparked by changes in the non-farm sector. Growing urbanization, increasing opportunities in nonagricultural employment, and relatively high incomes have set the pace for the state. Agricultural developments have involved more capital intensive and less labor intensive production. Growing emphasis on dalrying, beef cattle, and poultry production has contributed to much of tre agricultural change, although cotton culture has persisted in SEA 4a. On the other hand, in the Coastal Plain, agricultural development based on the traditional labor intensive crops--peanuts, cotton, and tobacco--st11l holds sway. Fruits, vegetables and nuts have become important in only a few dispersed areas. Growth in secondary and tertiary economic activities, ordinarily assoclated with urbanization has been much more limited than in the Pledmont. But even without this factor of urbanization, the level of living of the Coastal Plain farmer, especially in SEA $7 \mathrm{~b}$, has grown as fast, if not faster, than that of the Pledmont farmer. 
CHAPTER III

\section{ANALYSIS OF DIVERSIFICATION}

This chapter deals with the first objective of this dissertation--determining the agricultural diversification of each of the selected 105 Georgia counties for 1939, 1949, and 1959. The first section of this chapter is an account of some events and policies of the 1930 to 1960 period that influenced agricultural production in some way. This information provides a background necessary for a more complete understanding of the nature and the distribution of diversification presented later in the chapter. This is followed by an analysis of diversification based on the acreage devoted to pasture and the seven leading crops. The rinal section of the chapter is an analysis of diversification based on the source of income from the sale of farm products.

Background of Events and Policies, 1930-60 During the $1930 \mathrm{~s}$, the United States was coping with problems growing out of an economic depression. Total domestic production of all goods reached a low point bringing in its wake unemployment and an inability to buy. 
The ratio of prices recelved by farmers to those pald by farmers reached its minimum in 1932 of about 60 $(1910-14=100)$. This acute situation was aggravated by the accumulation of farm surpluses which in turn was abetted by the return of many erstwhile city dwellers to the farm. The Agricultural Adjustment Act, passed in 1933, sought to bring farm production more in line with demand and thus ralse the level of farm income. Incentives in the form of loans and price supports at varying levels of parity were offered to farmers in order to induce them to Join the government programs of acreage reductions for certain "basic commodities." These commodities were cornhogs, cotton, wheat, tobacco, peanuts, and rice. Others were later added. It is almost impossible to assess the extent to which this measure contributed to improving farm Income because of a general improvement in the economic situation effected through other remedies. By 1936, acreages had been reduced, production checked, and prices recelved by farmers in relation to those they paid had Increased.

The section of the 1933 Agricultural Adjustment Act (AAA) levying a tax on processors of farm commodities was invalidated by the supreme court in 1936. Since these levies had been used to help finance the loan and parity payments to farmers, the AAA programs were discontinued. Two years later a similar act, but now divested of the 
processors levy and providing for soll conservation, was passed. Most of the basic products for the 1937 and 1938 crop years had increases in acreage and in production as acreage quotas were not Imposed in these years.

Acreage allotments were restored in 1939 and the expansion of land from which these basic commodities were harvested was halted. Cotton and tobacco were the crops affected by this measure in Georgla in the 1939 census year. Acreage allotments for peanuts were not voted in until the 1941 crop year. Corn and other grains were not affected since Georgia counties were not included in the commercial grain raising part of the country.

Between 1939 and 1949, the Second World War Intervened and beyond a doubt contributed to an economic recovery that was well underway by 1941. Agricultural production on nearly all fronts rose in response to increased demand for rarm products. Acreage quotas were abandoned for the duration of the war and until shortly thereafter. The production of peanuts and other oll bearing crops was encouraged by the government. This was such a boost to peanut production that even by 1950, the acres of peanuts grown alone exceeded that for 1940. After 1950, however, this growth had been checked by postwar adjustments to lower demand for the domestic crop. Surpluses of food and feed crops were reduced or eliminated during the war, although it was not until the war was over that the cotton carry-over was reduced. 
This prosperity was not to continue for many years after the war. The ratio of prices recelved by farmers to the prices that they had to pay continued to increase in the 1940 's up to 1947 for the United States as a whole. Thereafter, a decline set in because farmers were unable to adjust production to decreasing post war demands. Once more prices fell and surpluses of farm commodities accumulated. As agricultural production expenses continued to rise, farm incomes dropped.

The outlook in Georgia can be summed up in the following quotation taken from Treanor's Georg1a's 1949 Agricultural Outlook.

Supplies of practically all the major cash crops in which Georgla farmers are interested have increased to the point where downward adjustment in production w1ll soon be ner...sary if prices and incomes are to be maintained. Furthermore, unless there should be war, the squeeze between prices which farmers pay and prices which they recelve is likely to become tighter in 1949. The coming year will necessitate adjustments from two standpoints. One w111 Involve acreage adjustments in order to comply with acreage allotments and marketing quotas which have been or w11l be imposed. The other will involve adjustments to meet changing price levels.1

of the four major crops grown in Georgia in the 1949 census year--corn, cotton, peanuts, and tobacco--only the last two were grown under acreage controls. It was generally

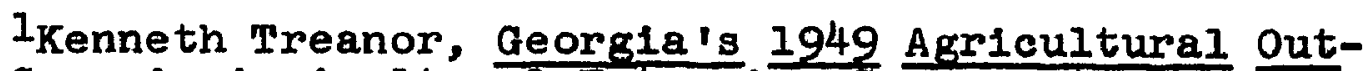
look, Georgla Agricultural Extension Service Circular, No. 353 (Athens, 1948), p. 5 . 
known that acreage restrictions for cotton were likely in 1950. This knowledge led many farmers to increase their planting, even beyond what they thought they could harvest, so as to maximize their allotments under acreage control programs anticipated for 1950. The allotted tobacco area was above the 1948 acreage in 1949, thereafter rising until 1952. Peanut acreage allotments resulted in a decline in acreage in the state from $1,169,000$ acres in 1948 to 783,000 acres in 1949. Thereafter the trend was downward.2 (These figures are adjusted to convert peanuts grown with other crops to an equivalent area of those grown alone.)

Following 1949, 1t was becoming clear that a secular trend of over-production and under-consumption of several farm commodities was underway. The Second World War and then the Korean War were only brief perlods of respite. The seriousness of this situation was summarized by Christensen and Alnes, in a publication entitled, Economic Effects of Acreage Control Programs in the 1950 's. 3

Declining prices and incomes accompanied excess production and stock accumulations. Prices

${ }^{2}$. E. Ford, The Supply, Price, Value, and Disposition of Peanuts, Georgia Agricultural Experiment stations, University of Georgia College of Agriculture Mimeo Series, N.S. 143 (Athens, 1962), p. 39.

$3_{\text {Raymond } P \text {. Christensen and Ronald } 0 \text {. Alnes, Economic }}$ Effects of Acreage Control Programs in the 1950's, Un1ted States Department of Agriculture, Agricultural Economic Report, No. 18 (Washington: U.S. Government Printing office, 1962), p. 4. 
recelved for farm products averaged nearly a fourth lower in 1955 than in 1951, while those pald by farmers were slightly lower. Realized net income of farm operators from farming including government payments decreased from $\$ 15.2$ bi11ion in 1951 to $\$ 11.5$ billion in 1959, or nearly a fourth.

It was as an attempt to remedy this situation that the So11 Bank Act of 1956 was passed. It embraced two distinct features. The first was the Acreage Reserve Program, under which farmers could have made one year agreements in 1956, 1957, and 1958 to reduce acreages of wheat, corn, cotton, rice, peanuts, and tobacco below their allotted acreages and receive payments to compensate them for their 10ss of income. The second feature was the Conservation Reserve Program of the Soll Bank under which farmers could make contracts for three to ten years (beginning in 1956 and running through 1960) to reduce acreages of harvested crops and recelve rental payments each year of contract and practice payments to help pay the cost of establishing conservation cover when needed on land retired from harvested use.

The major effects of this program on farm acreage were as follows: (I) to decrease harvested cropland of the quota crops (cotton and peanuts were the major crops affected in the area covered by this study) and (2) to Increase the harvested area of non-quota crops such as soybeans and sorghum and even the relative area of corn in 
the state of Georgia, whlch had escaped earlier quotas since it was outside the area of commercial corn production. The increase in the preparation of land used for growing other grains and hay, for foreated farmland, and for pastured cropland was also noted in many counties as a result of the Soll Bank and other programs.

Hence, these conditions in the state and nation have had their influence on the trends that the data for 1939, 1949, and 1959 show. The Second World War and the Korean War seem to have had the effect of retarding secular trends in harvested cropland and production. The census years of 1939, 1949, and 1959 have the advantage of comparability of data to some degree. They were not war years and some kind of acreage control program was in force for each year.

Land use diversification analysis

The analysis of land use divergification is the main objective of this section of chapter III. The extent of diversification is calculated for the 105 Georgia counties selected for investigation on a basis of the acreage of cropland used for pasture and the seven leading crops. These values are presented and discussed for each county for 1939, 1949, and 1959. Changes in diversification between 1939-49 and 1949-59 are also considered in order to portray the dynamic character of this phenomenon. Gini coefficients of concentration were computed for each county. These data were plotted on maps using circles 
where the size of the circles was drawn proportionate to the amount of diversification and inversely proportionate to the value of the Ginl coefficients. Each circle was subdivided so as to show the relative magnitude of the various land uses. All land uses representing as much as 11 per cent of the total acreage of the seven crops and pastured cropland comblned were shown in these clrcles. In addition, these circles showed all other crops needed to represent at least three-fourths of th1s total acreage. These circles are often referred to as acreage structures In the passages below.

Labels have been assigned to Gini coefficients of given magnitudes to facilitate description of divergification. "High diversirication" and "moderate diversification" are derined as having Gini coefficients of .50 or less and .5I to .60, respectively. "Moderate concentration" and "high concentration" are defined by coefficients ranging from .61 to .70, and .71 and over, respectively. Diversification in 1939. The classes of diversification shown on Maps VIII and IX fall within the framework of definitions used above. The two maps are similar, but Map IX was compiled in order to emphasize the various land uses. By not showing the land uses, Map VIII more clearly portrays the extent of diversification. Th1s procedure of using the two maps to show diversification was followed throughout this chapter. 


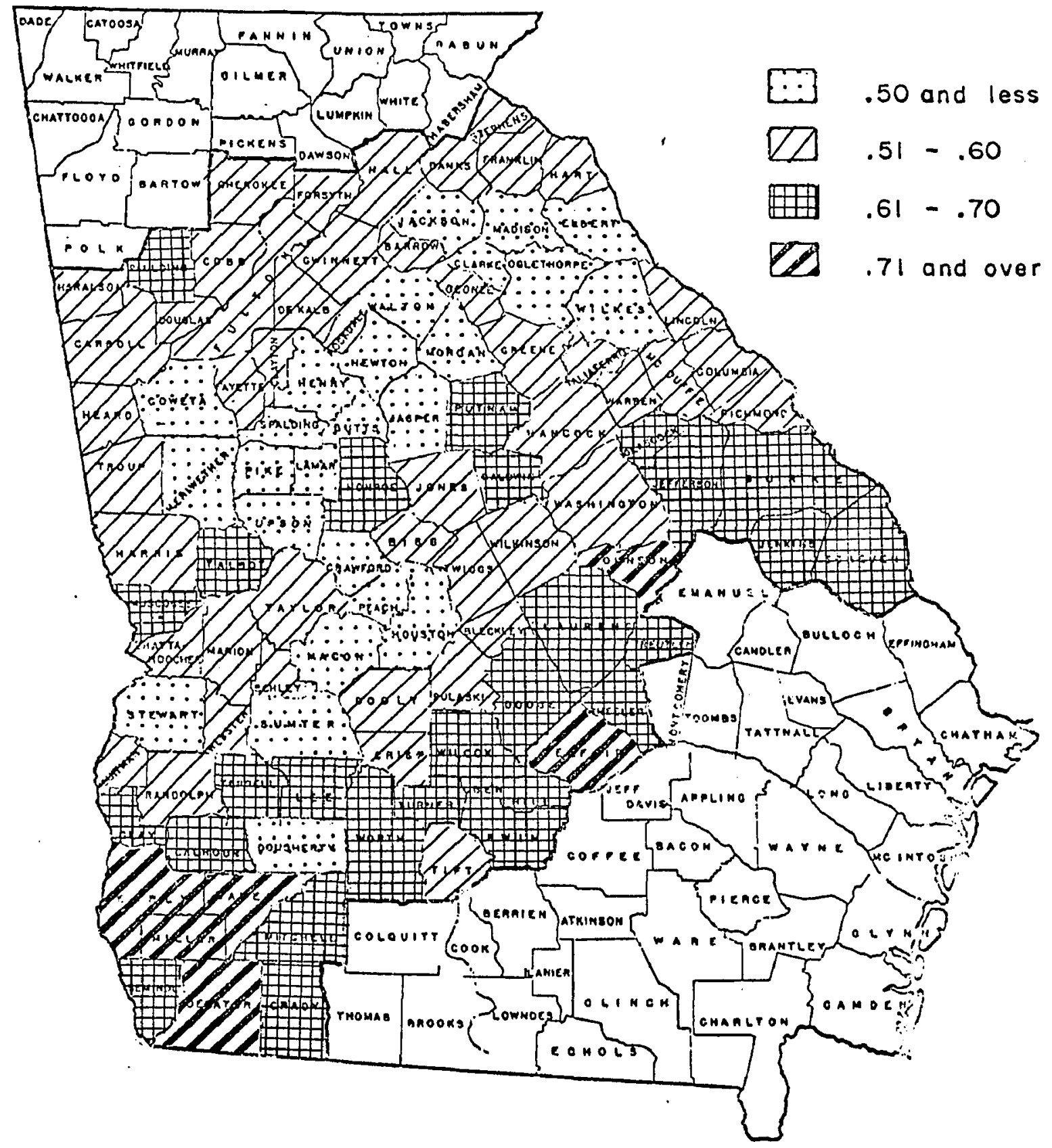

MAP VIII

GINI COEFFICIENTS BASED ON LAND USE FOR 105 GEORGIA COUNTIES, 1939 


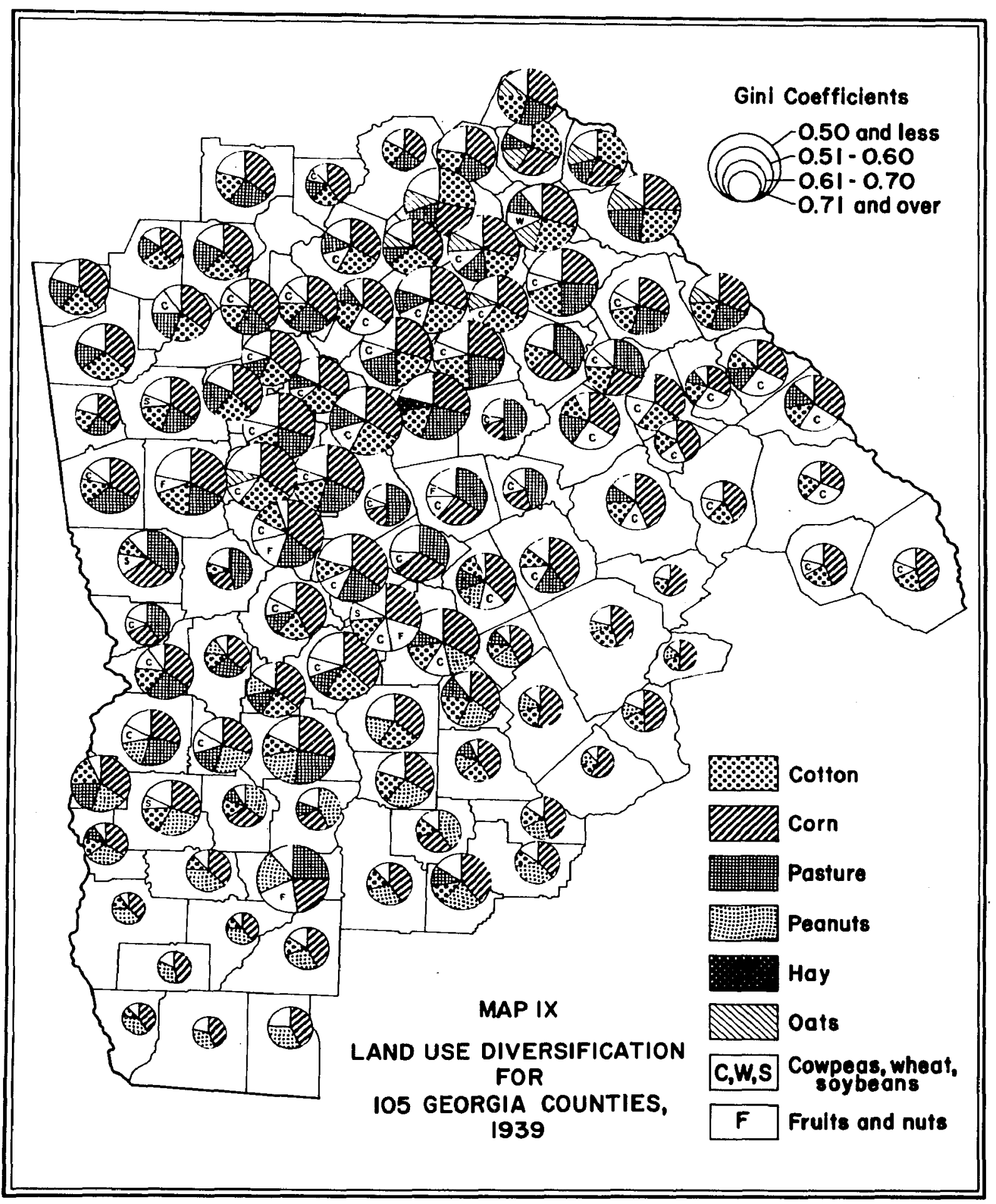


There were two areas of high diversiflcation in 1939. The first of these was located in the Pledmont. It extended unbroken, except for Oconee county, from the South Carolina border to Heard and Troup counties in the west. Through the Iink of Crawford and Upson counties it was connected with a second highly diversified cluster of counties centered on Peach County. Dougherty County, further south, and Stewart County, farther west, were outliers. The best description of the land use combination of the easternmost part of the highly diversifled zone in the Pledmont was corn-cotton-pasture-oats in 1939. Corn was usually the first place crop, while pasture and cotton vied for second place. Oats, and less frequently, wheat entered into the acreage structure in the east, giving way to cowpeas in the west. Thus, the westernmost section of this diversified zone could be represented by a corn-pasturecotton-cowpeas combination.

In the highly divergifled zone centered on Peach County to the south, corn, pasture, cotton, and cowpeas were still 1mportant. In addition, peach trees and peanuts were present. The peanuts contributed to the greater diversification in Sumter and Houston counties and, in a sense, these two counties were a transition between the corn-cotton-pasture-cowpeas complex in the north and the corn-peanuts complex farther south. 
Areas of moderate diversification interspersed with 1slands of moderate concentration lay to the north, west, and south of the diversified zone in the central pledmont described above. Less diversification occurred along the northernmost of these perimeters because the crop structure consisted of only three types of land uses in contrast to the prevaling four types in the diversifled zone farther south. This was a corn-pasture-cotton combination. The cowpeas had been eliminated. Franklin and Hart counties were two of only three counties in the state (Jackson County was the third) where cotton ranked first in the land use combination.

Lying to the south of the highly diversified zone of the Pledmont was an area of moderate diversification and a few islands of moderate concentration extending into the Coastal Plaln. This increased concentration encountered In moving southward resulted from a greater proportion of the total cropland belng used for the leading crop, usually corn, rather than from any change in the components of the crop structure. The 1slands of moderate concentration consisting of Putnam, Baldwin, Monroe, and Talbot counties had enough land in pastured cropland, their leading land use, to raise their status to that of moderate concentration. This use of pastureland was associated with increased cattle production for milk in the first three counties and meat in the latter. 
In 1939, the Coastal Plain, in general, was less diversifled than the Pledmont. But extremes were observed ranging from the highly diversified cluster of counties around Peach County to the highly concentrated cluster of counties in the southwest, Including Early, Baker, Miller, and Decatur. Corn was the highest ranking crop in the Coastal Plain except in Terrell, Lee, and Turner countles where peanuts were most important and in urbanized Dougherty County where pasture led all others. As a rule, pasture was relatively less important in the Coastal Plain than in the Piedmont. In many of the counties here, pastured cropland was so minor that it was not represented in the acreage structure. A partial explanation for this was the greater emphasis in hog production than cattle in the Coastal Plain and the fact that urbanization and industrialization had not been sufficlently great to warrant diverting land from the traditional row crops. Acreage control programs changed this picture later on.

The high concentration in Early, Miller, Baker, and Decatur counties (Seminole County was marginal) resulted from the high proportion of the land used for growing corn rather than peanuts. It may be noted also that the rank of cotton was so low that it was squeezed out of the acreage structure altogether in many countles of the southwest. Even in Burke, Jefferson, Jenkins, and Johnson counties, one of the major cotton growing areas, cotton 
was second place or even in third place. Nearly surrounding the highly diversifled zone centered on Peach County was an area of moderate diversification. In the area on the west, centered on stewart County, the land use combination Included corn, pasture, peanuts, cotton, cowpeas, and soybeans. The counties of moderate diversification to the east were in the area of transition between the corn-cottoncowpeas area in the eastern Coastal Plain and the cornpeanut-cotton counties of the western Coastal Plain.

Diversification in 1949 and 1949-59. Maps $X, X I$ and XII should be used to follow the discussion below on the status of diversification in 1949 and the change in diversiflcation between 1939 and 1949. A comparison of the 1949 maps with those for 1939 reveals a number of trends.

First, the two highly diversified zones of 1939 had so segmented that in 1949 they had become three separate clusters and two outliers--Dougherty and RIchmond counties. In general, these three new highly diversified clusters consisted of a core of the counties that had the same status in 1939 in addition to new ones captured from surrounding areas. This core became even more diversified except for Jasper, Morgan, and Walton countles which made substantial gains toward concentration. The accompanying land use changes in this region involved a shift of cotton from second and third positions to leading rank and the substitution of hay for cowpeas. The cowpeas expansion 


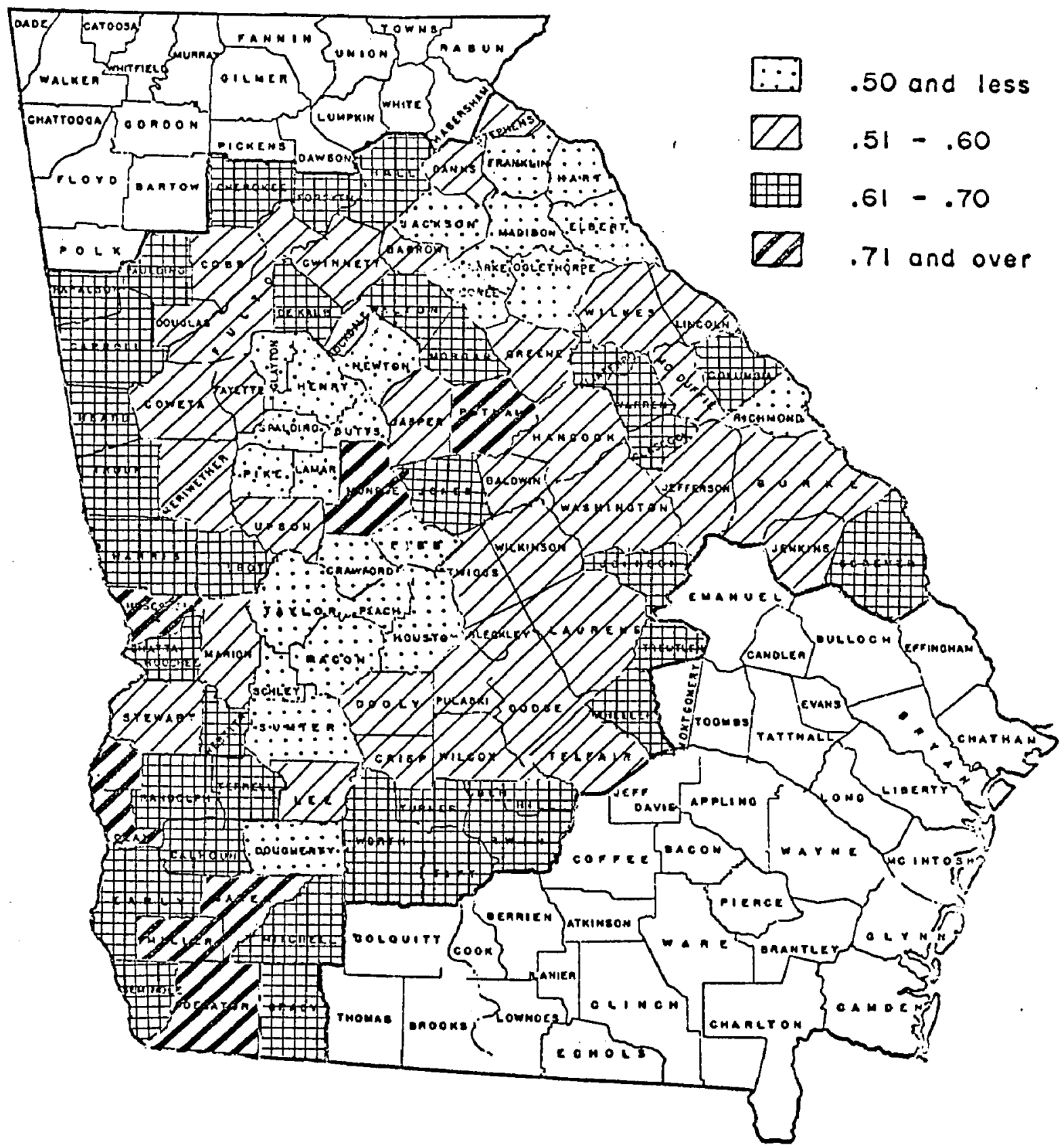

MAP X

GINI COEFFICIENTS BASED ON LAND USE FOR IOS GEORGIA COUNTIES, 1949 


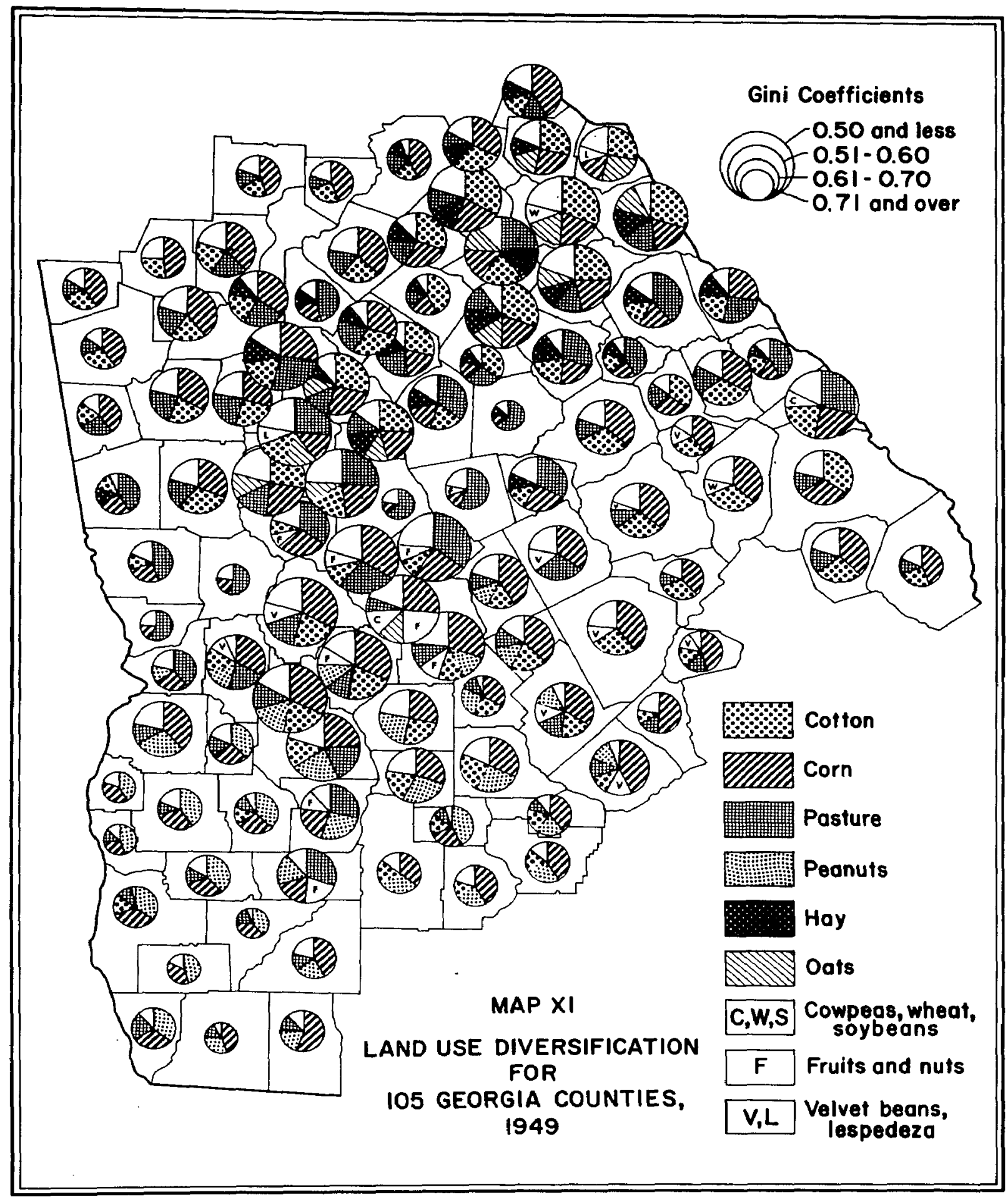




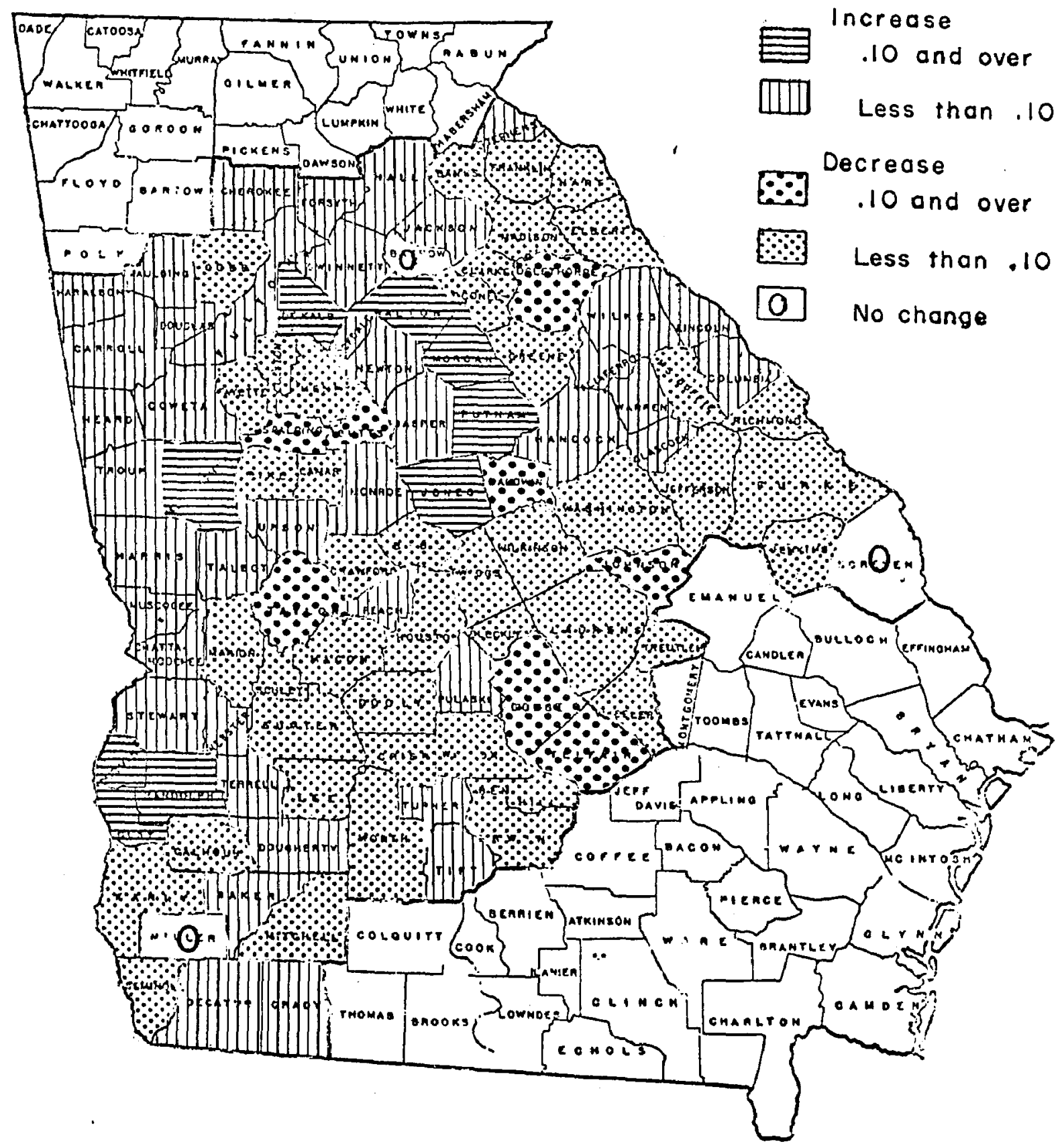

MAP XII

CHANGE IN GINI COEFFICIENTS BASED

ON LAND USE FOR 105 GEORGIA

COUNTIES, $1939-49$ 
had been curtalled partiy as a result of the inability of the farmers to check the damage of the curculio worm which attacked the cowpea pod. One of the reasons for the 1949 expansion in the cotton acreage was that farmers expected acreage quotas for the 1950 crop year which would have been on their 1949 plantings, and therefore, planted more cotton in the hope of maximizing future acreage quotas. In the highly diversified counties centered on Peach County, the kind of land use did not change except in minor detall from that of 1939. Rather, the land uses assumed different proportions in 1949.

A second change was that the area lying to the north and west of the 1939 highly diversifled zone of the Pledmont became slightly more concentrated by 1949. Th1s increase in concentration was accompanied by the devotion of relatively more land to the production of corn while the other elements of the acreage structure remalned virtually unchanged from that of a decade ago. The trend toward corn dominance was reversed in DeKalb and Troup counties as pasture replaced corn as the leading land use. These two cases most 11kely represented a basic secular trend, relatively pronounced in urbanized-industrialized counties, that was too strong to be reversed by the attractive prospects of higher acreage allotments for cotton. Throughout most of the rest of the state in the southern Pledmont and the Coastal Plain, the trend was 
toward increasing diversification. The major exception was a group of counties, Including Clay, Randolph, Quitman, Stewart, and Webster in the western Coastal Plain. This group rose to the highly concentrated and moderately concentrated category. Peanuts moved from second and third places to become the highest ranking land use, while cotton In many cases was eliminated from the crop structure. It has already been pointed out that the production of peanuts and other oll bearing crops had been especlally encouraged by the federal government during the second world War. By the year 1949, all the momentum of production that characterlzed the war years was not yet 1ost. Moreover, the gains in peanut prices made during the war had been maintained. Average prices per pound recelved by farmers increased from three cents in 1939 to 10 cents in 1949. 4 In the eastern part of the Coastal Plain and the southern Piedmont, increased diversification in 1949 was brought about through the relative expansion of pasture. Burke, Jenkins, and Screven counties are good examples of this. However, the .18 point decrease in the Gini coeff1clent in Baldwin County was associated with a contraction of pastured cropland and the entrance of cotton and hay into the acreage structure. In Dodge and Telfair counties, where the GinI coefficient fell .17 points for each, the

\footnotetext{
${ }^{4}$ Agricultural Statistics, 1963 (Washington: United States Government PrintIng Of'ice, 1964), p. 155.
} 
Increasing diversification that came about as a result of the expansion in pastureland and velvet beans may have been overstated because no adjustment was made in these data by converting the acres grown with other orops into equivalents of the acreage grown alone.

Diversification in 1959 and 1949-59. At this point some of the changes that occurred between 1949 and 1959 and the status of diversification in 1959 w11l be examined. Maps XIII, XIV, and XV should be used.

The basic change between 1949 and 1959 was toward increasing concentration, especially in the Pledmont. Nevertheless, the northeastern Pledmont and the southeastern Pledmont-eastern Coastal Plain became more diversifled as they followed the trend set in the 1939-49 decade. In the land use changes, pastureland had risen to leading position in over four-fifths of the Piedmont counties. This relative increase in pastureland was apparently made at the expense of cotton and corn. All over the state the decline of cotton was most obvious as it disappeared from the acreage structures in many counties and was reduced in others.

Of the three 1slands of diversification that appeared on the 1949 maps, one had almost disappeared by 1959. Because Meriwether County became more diversifled in 1959 reversing the 1939-49 trend toward concentration, the western highly diversifled zone in the Pledmont did not 


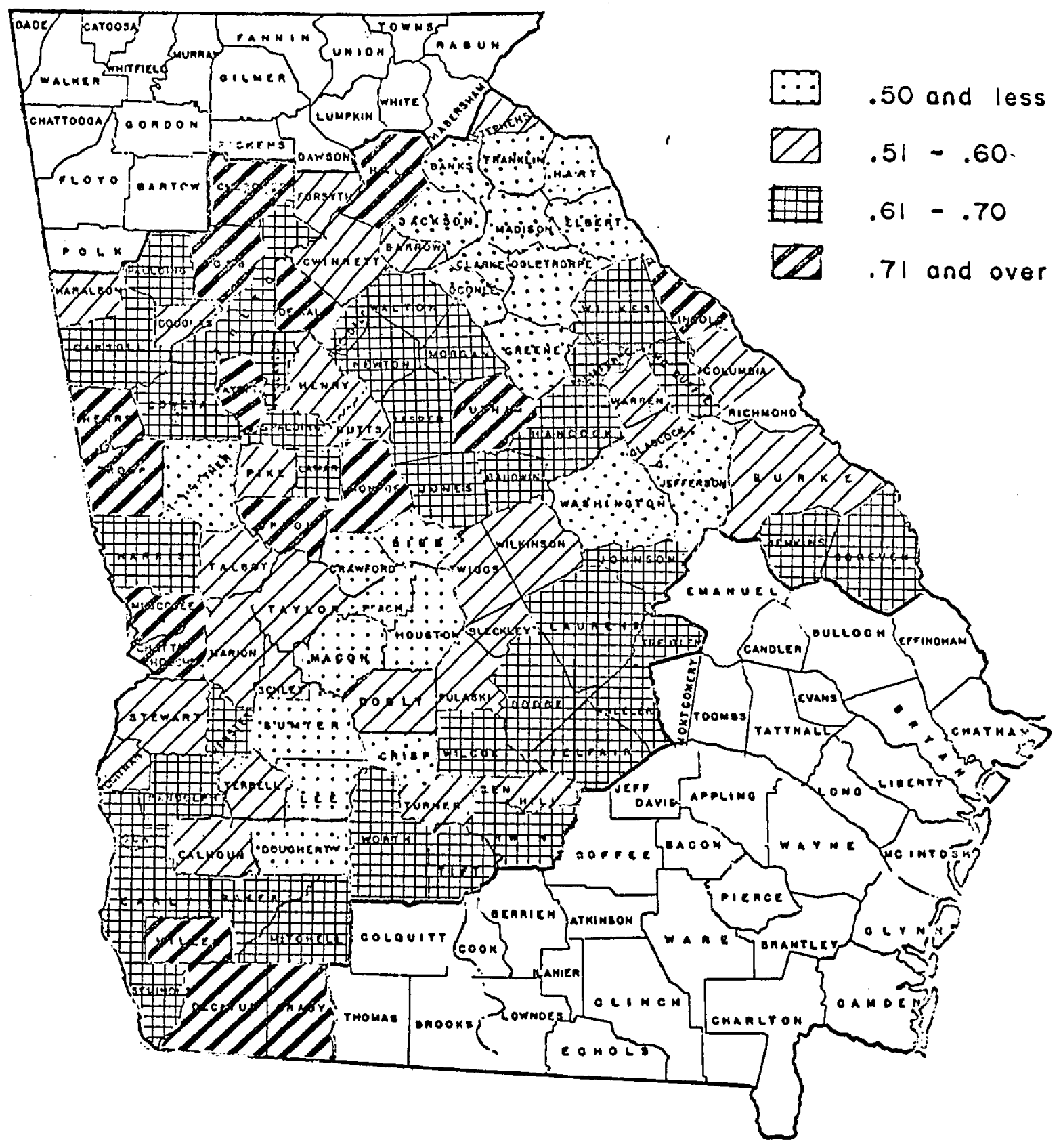

MAP X 11

GINI COEFFICIENTS BASED ON LAND USE FOR 105 GEORGIA COUNTIES, 1959 


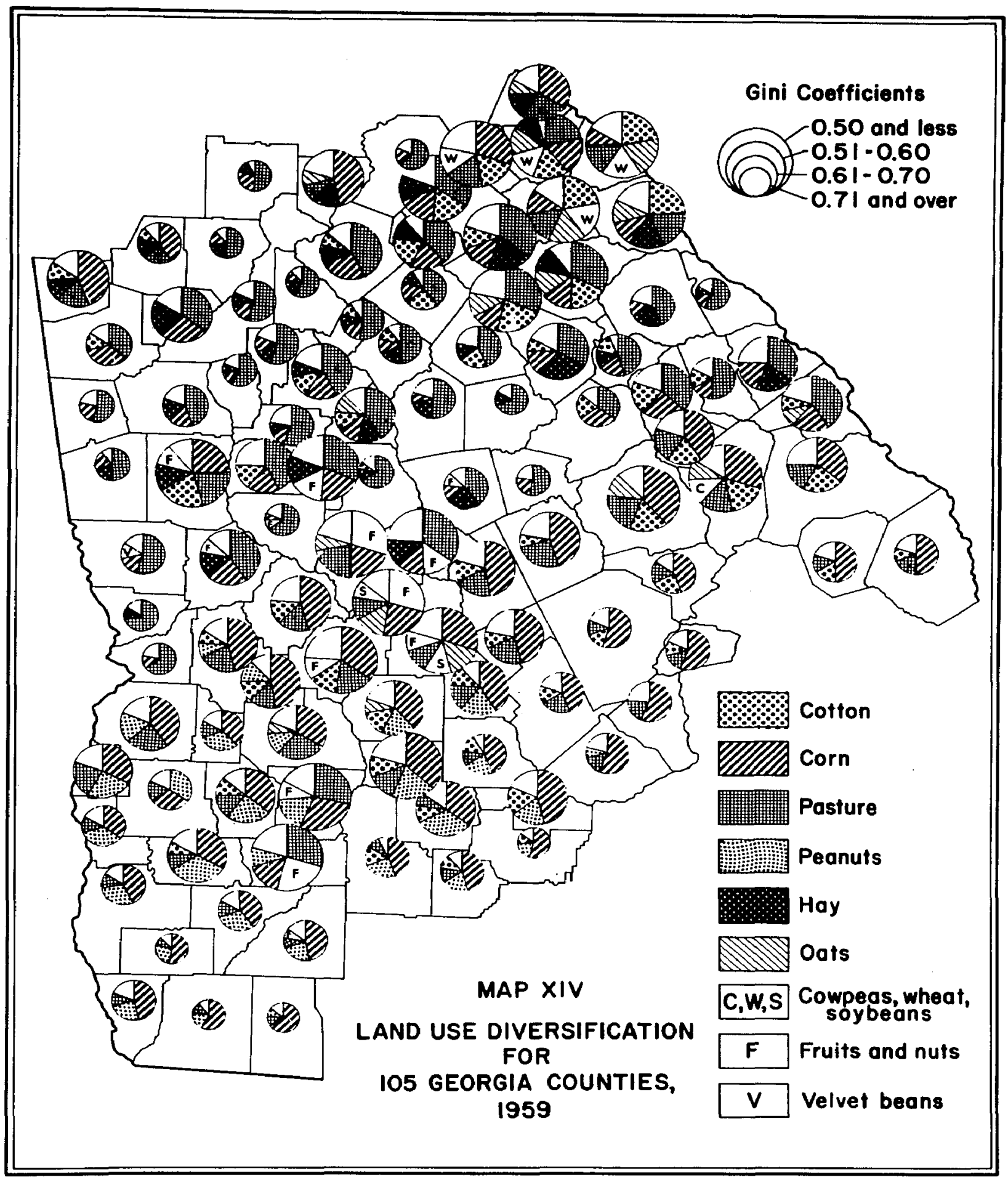




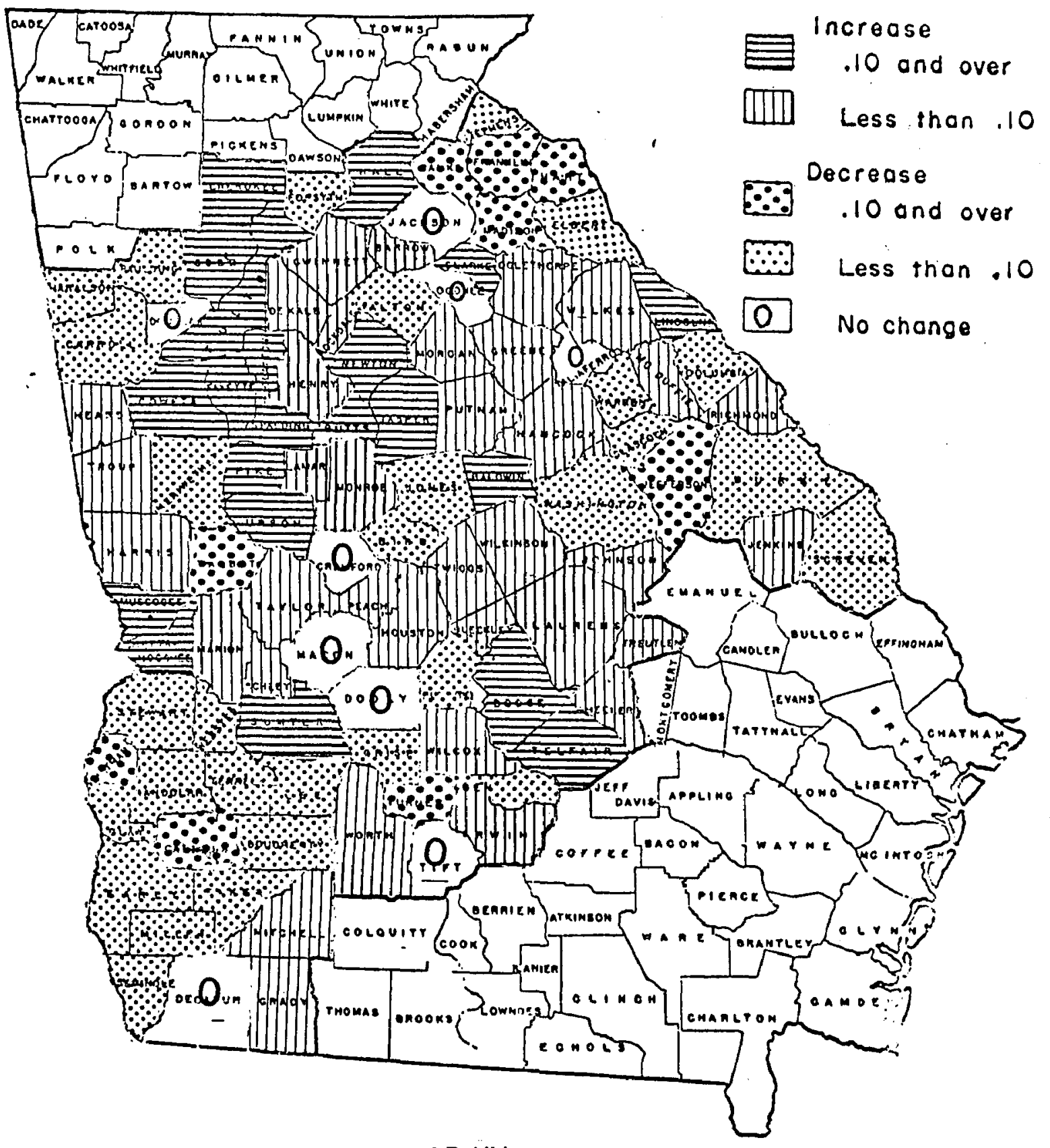

MAP XV

CHANGE IN GINI COEFFICIENTS BASED

ON LAND USE FOR 105 GEORGIA COUNTIES, 1949-59 
completely disappear. In the 1939-49 decade most of the counties in the highly divergifled zone of the western Pledmont had made sizeable gains in diversification. In the 1949-59 decade this trend was reversed. For example, Spalding and clayton counties had Ginf coefficient gains of . 31 and .20, respectively in this decade. These gains were associated with increases in the proportion of pasture and decreases in the proportion of cotton. Hay production was a third ranking land use. Pecan trees became relatively more important in Lamar County. This group of counties could very well have been responding to increasing urbanization in the Atlanta-Griffin urbanized area. Another highly diversifled area in the northeastern Piedmont, centered on Madison County, became more diversifled. Franklin, Hart, and Banks counties had GInl coefficlent losses of $.17, .15$, and .13 , respectively between 1949 and 1959. These increases in diversification were apparently related to the reluctance of farmers to devote more land to pasture and their unwillingness to remove cotton from its secure position. In Hart, Madison, and Elbert counties cotton was the highest ranking crop in the acreage structures both in 1949 and 1959.

The highly diversifled zone which was centered on Peach County in 1939 and 1949 extended southward to include Crisp and Dougherty counties. Except in Sumter County, the trend toward diversiflcation or concentration had been weak. 
The major changes in land use were the inclusion of oats and soybeans in the acreage structures and the strengthening of the position of pasture. In Crawford and Peach counties peaches moved up to the first place displacing corn from this rank.

Washington and Jefferson countles emerged as highly diversified counties in 1959 after consistent trends in this direction in the 1939-49 and 1949-59 decades. The diminished influence of corn, the relatively greater signiflcance of pasture and the entry of oats into the acreage structure contributed to the 1949-59 trend. These two counties were a part of a much larger cotton growing region in the Inner coastal Plain. It is of interest to note here that cotton has maintained a second place position since 1939. Cotton remalned equaliy tenacious in the eastern Pledmont as was mentioned above. The question arises here as to whether the slowness of cotton in being eliminated from the acreage structure is the result of 1ts having been "frozen" into place by higher allotments or whether in light of markets and the growing environment it has a comparative advantage over other crops that could be grown. Of course, It could be a kind of psychological inertia on the part of the farmers in the area.

Changes in diversification in other parts of the Coastal Plain were slight or variable. Dodge and Telfair counties in the central part of the Coastal Pla1n, Quitman 
and Calhoun counties on the west, and Turner County in between were the major exceptions. Dodge and Telfair became more concentrated in the 1949-59 decade reversing their 1939-49 trend. Corn became more prominent and velvet beans vanished from the crop structure altogether. Quitman and Calhoun countles, and to a smaller degree Clay County, became more diversified as pastureland and corn gained at the expense of peanuts. Total peanut acreage fell from 783,000 acres in 1949 to 490,000 acres in 1959 as a result of the Soll. Bank and other acreage control programs.5 In the southwestern part of the coastal Plain where the 1959 Gini coefficlent remained the same as that of 1949, there were shifts in the corn-pasture combinations. As a rule, corn assumed first place position as peanuts moved to second place. This same kind of shift in the position of corn and peanuts was observed in Turner County. The profiles of changes over the $1939-49$ and 1949-59 decades are shown on Map XVI. There were four categorles into which most of the profiles fell: (1) a trend toward concentration for both decades (symbol = $\backslash$ ); (2) a trend toward diversification in the first decade and concentration In the second one $($ symbol $=\wedge) ;(3)$ a trend toward divers1fication in both decades (symbol =/); and (4) a trend

$$
5 \text { Ford, op. c1t., pp. } 39 \text { and } 40 .
$$


toward concentration in the first decade and toward diversification over the 1949-59 period (symbol = $v$ ).

The first profile was found mainly in the Pledmont and Fall IIne Sand Hills. About one-third of all the counties in these two regions trended toward concentration for both decades. The second type profile was even more widespread. It was found in the central Pledmont and coastal Plain. Reasons for these changes have already been pointed out. For most of the Pledmont counties, however, the net change of counties having this profile was toward increased concentration. The major cotton growing regions showed trends toward diversification for both decades. A weak trend of this nature was also observed in the Coastal Plain. Thus, the third profile was more or less unique for regions where cotton has been able to malntain itself in the crop structure. The fourth type of profile was found in the western Coastal Pla1n, northwestern Pledmont, and scattered in other counties.

The discussion above supports the argument that the Pledmont has become more concentrated. This trend has been effected through expanding the land used for pasture and hay. Furthermore, this condition suggests an advancement of this part of the state beyond the position of the coastal Plain along some kind of continuum emphasizing row crop production at one extreme, and livestock and livestockproduct production on the other. Is this advancement 
Change in Diversification

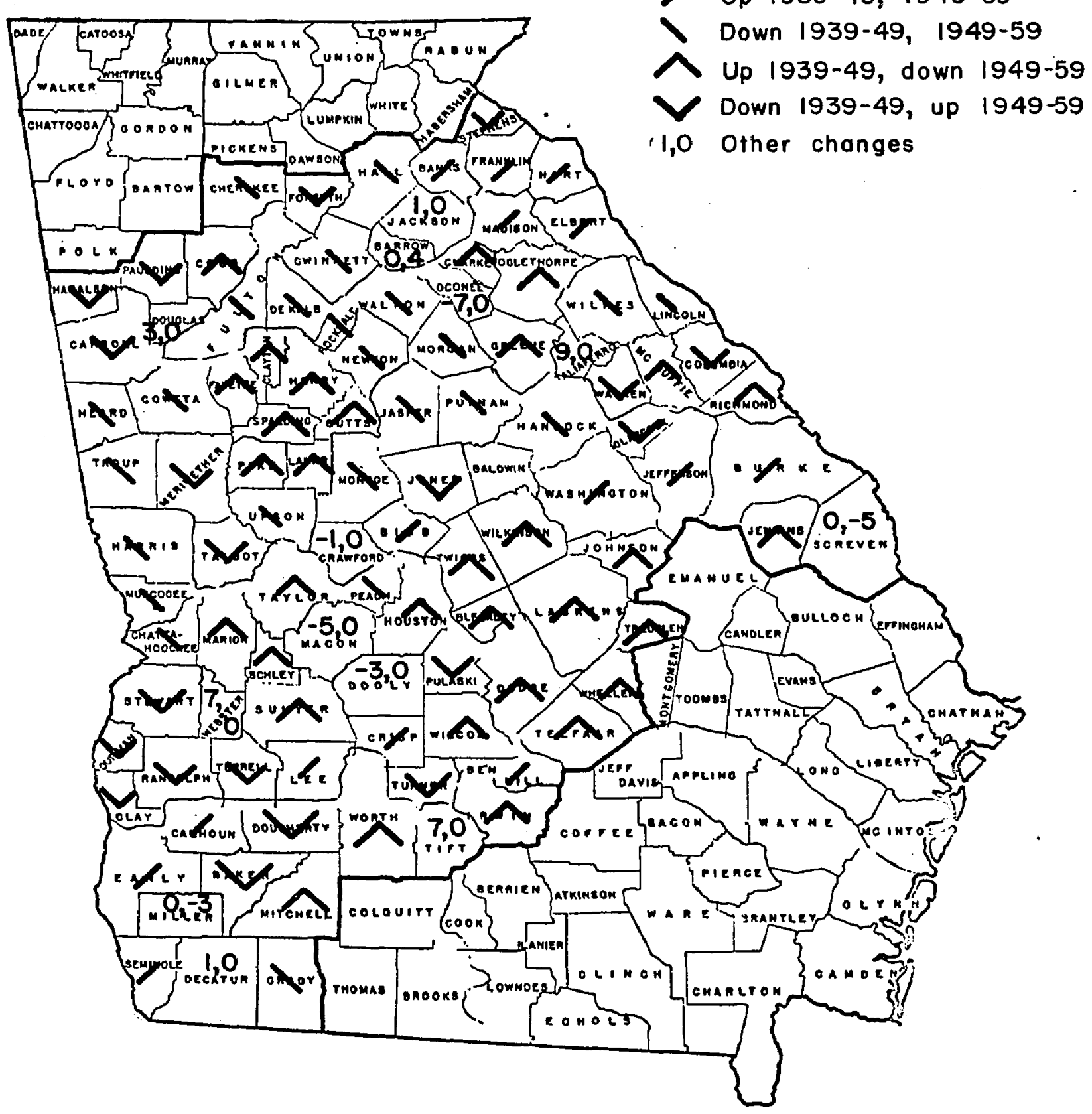

MAP XVI

PROFILES OF CHANGES IN LAND USE DIVERSIFICATION FOR IO5 GEORGIA COUNTIES, 1939-49 AND 1949-59 
assoclated with increasing urbanization, industrialization, and more extensive non-farm employment opportunities as Theodore Schultz suggests? ${ }^{6}$ Answers to these questions will be sought in a later section of this dissertation.

Analysis of Diversification Based on Value or Farm Products sold

The most obvious difference between diversification based on land use and that based on the value of cash receipts from farm products is that the latter is markedly more concentrated. Mean Gini coefficlents for the three years considered in this study ranged from .55 to .60 for the former and from .70 to .74 for the latter. Th1s las in diversification of the sources of income behind that of acreage has been referred to by many writers. An examination of census data reveals that even in the heyday of cotton production, corn and cotton occupled about equal proportions of the total cropland in Georgla, while cotton was the primary source of income.

For the entire state, cotton and peanuts, the leading crops, accounted for 35 and 8 per cent of the total sales of farm commodities, respectively, in the 1939 crop year. By 1949, the percentage for cotton had fallen to 24 and that for peanuts had risen to 13 per cent of sales.

6 Theodore W. Schultz, "Reflections on Poverty Within Agriculture," The Journal of Political Economy, IVIII (February, 1950), pp. 1-15. 
Livestock production has rapldly increased since the 1930's, but 1959 was the first census year that cash receipts from the sale of Iivestock and IIvestock products exceeded those from the sale of field crops. In 1955, brollers ranked first in the state as a source of farm income. Receipts from cotton in this year were down to 12 per cent of the state total while sales of peanuts almost held steady at 12 per cent of the total. 7

The strengthening of the position of livestock as a source of Income in Georgla resulted both from Increased production and higher prices. The index number of prices recelved by farmers for livestock and livestock products rose from 107 to 256 between 1939 and 1959, while that for crops rose from 82 to 221 over the same period. In both cases the base years of 100 were 1910-1914.8 Moreover, prices recelved for cattle and calves in Georgia increased relative to United States prices during the period 1924-55. Prices recelved for cattle in Georgla were only 66 per cent of United States prices in 1952. This Increase was partly due to improvement in the quality of the marketed cattle and to better markets. Although the discrepancy between

7 Cash Receipts from Major Farm Commodities by States, StatisticaI BuIletin No. 262, USDA (WashIngton: Ünted States Government Printing office, 1960), p. 12.

8 Agricultural Stat1stics (Washington: United States Government Printing offlce, 1963), p. 559 . 
United States and Georgia prices for swine was never so great as in the case of cattle, there was improvement in prices recelved for hogs, too: Hog prices increased consistently from 1933 to 1947. Since 1947 the overall trend in prices has been slightly downward.

A word of caution is urged in interpreting changes In the value of Ginl coefficlents based on the sale of farm products as necessarily indicative of change in the relative amounts of the goods sold. Relatively greater changes in livestock prices as compared with crop prices tend to magnify the role of livestock products as a source of Income at the expense of crops. This may lead to either over-estimating or under-estimating diversification based on the sale of farm products.

Diversification in 1939. At this point the extent of diversification for 1939 will be examined. This will then be followed by an examination of the years 1949 and 1959. Maps XVII and XVIII should be used for 1939. If a Gini coefficient of .60 is set as the upper Iimit of what shall be called "highly diversifled," the overall picture of diversification can be described as several highly diversifled islands containing or adjacent to urbanized areas in a sea of counties that are considerably more concentrated. An exception is the highly diversified but rural Telfair County. The urbanized counties are Fulton, Cobb, and Clayton of the Atlanta area; Richmond 


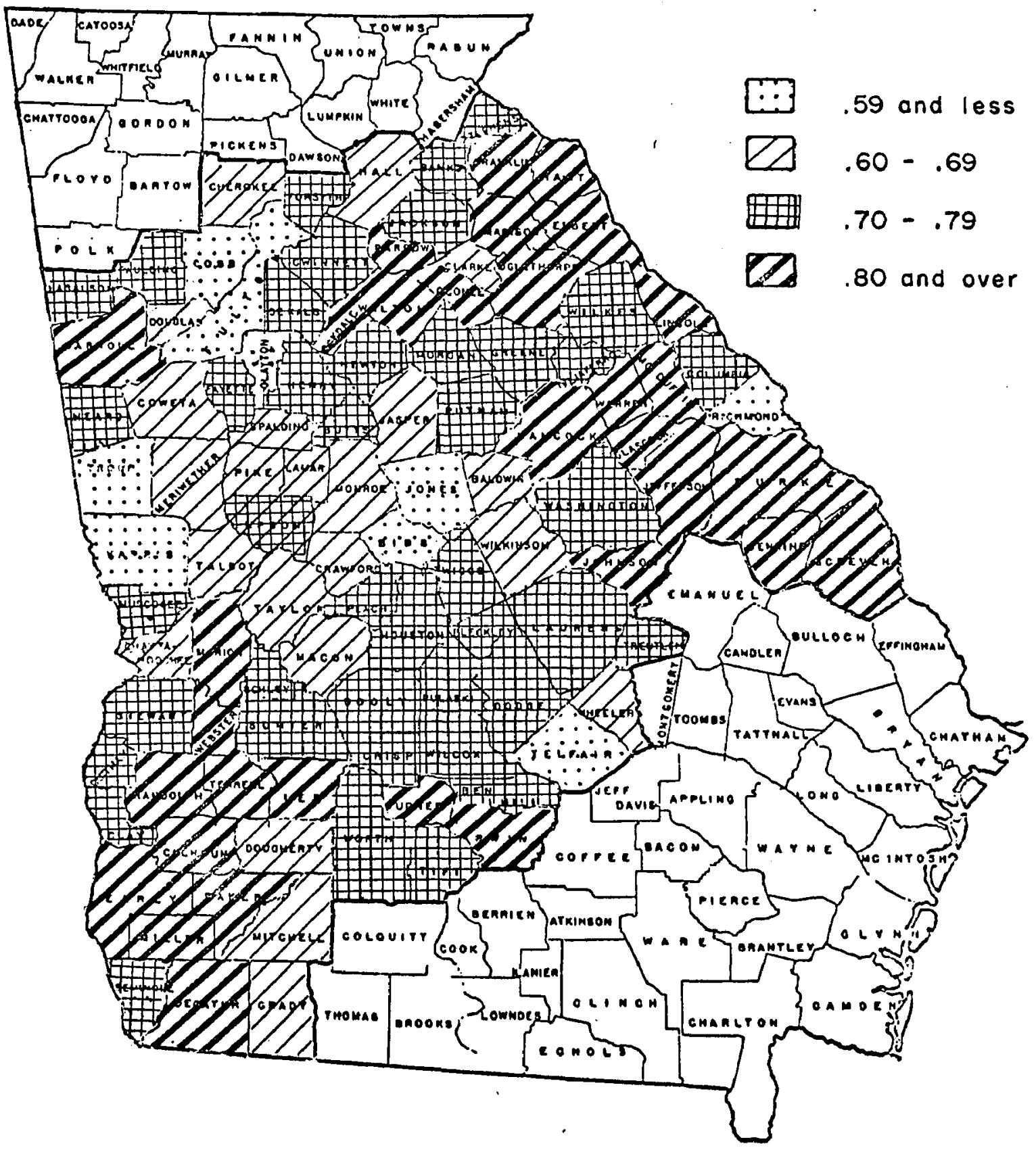

MAP XVII

GINI COEFFICIENTS BASED ON SALE OF FARM PRODUCTS FOR 105 GEORGIA. COUNTIES, 1939 


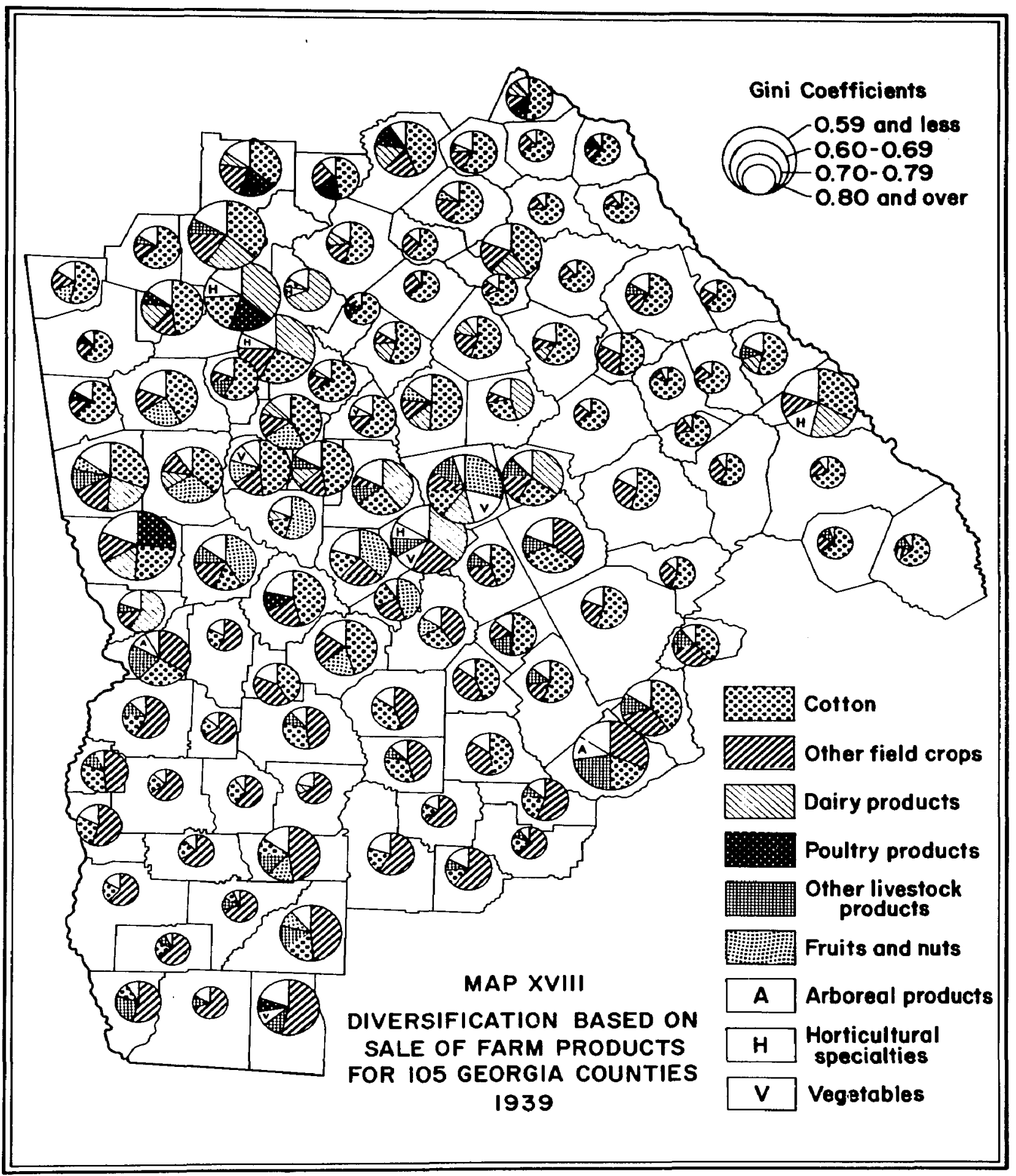


County, containing Augusta; $\mathrm{B} i \mathrm{bb}$ and Jones counties in the Macon area, and Troup and Harris counties around the West Point-Ia Grange complex. In a sense, these were counties In the vanguard moving away from the dominance of row crops in their income structures. Dalrying was common to all of them and it was the major source of cash income in three. Cotton and horticultural specialties (greenhouse and nursery products, flower and vegetable seeds, and flowers and plants grown in the open fall in this category) were found in all except Troup, where the latter products were absent from the income structure. Sales of flowers and other greenhouse products clearly reflect urban tastes and demand. Poultry, livestock products, other than dairy and poultry, fruit, and vegetables were other products in these counties. Other countles showing a smaller degree of diversification, but clearly less concentrated than their neighbors were Clarke, Hall, Dougherty, and Baldwin contalning Athens, Galnesville, Albany, and Milledgeville, respectively. However, it must be noted that not all counties having urbanized areas were so diversified. Muscogee County (Columbus) and DeKaIb County (Atlanta) were more concentrated than the highly diversifled 1slands by at least .20 points and had their incomes dominated by dalrying.

In this same year, three areas of relatively high concentration were delineated. High concentration is defined as having a Ginl coefflclent greater than .80. The first 
of these was in the eastern Pledmont. The second area was located in the southeastern Piedmont and adjacent parts of the Coastal Plain. It extended southeastward rrom Hancock County to Screven County. Washington County was marginaI, having a Gini coefficient of .77. The third section of the state with high concentration was in the southwestern part of the Atlantic Coastal Plain. Cotton was the primary source of income in each of these except the latter where peanuts were the major source of income. The concentration was of such intensity that 60 to 80 per cent of farm income In these counties was derived from cotton in the case of the first two areas. In the latter area, peanuts, or peanuts combined with tobacco were the leading sources of income. It is of interest to note that the first two of these areas of high income concentration colncided with areas of relatively high land use diversifloation.

Over the remalnder of the state, diversification was intermediate between the extremes of high concentration and high diversification discussed above. The area of moderate concentration in the coastal Plain appeared to have been a transition, both on a basis of the Ginl coeffiolent and the location. To the east, was a region where cotton was dominant; to the southwest, peanuts; and to the south, tobacco. Ben Hill county is an example of this type transition with a combination that could be classed as peanutscotton-tobacco-hogs. By classifying all fleld crops other 
than cotton together 1t was Impossible to make this kind of breakdown for the other counties without a large amount of added time and effort, while relatively little was to be galned from such an exercise. However, it was pointed out earller that tobacco was one of the leading sources of Income in SEA 7b while peanuts had this distinction in SEA 7a. Hogs were the dominant type livestock in both regions.

A zone of moderate concentration nearly surrounded the highly concentrated zone of the eastern Pledmont. Dairy products in the south and poultry in the north were factors accounting for this relatively moderate concentration. Putnam County, for example, by 1949 had become one of the major dairying counties in the state. By 1949, Hall County had emerged as the leading county in poultry sales; income from poultry represented three-fourths of cash receipts.

Paulding, Carroll, Haralson, and Heard counties in the northwestern Pledmont were considerably more concentrated than their neighbors to the south and east. Cotton sales accounted for 60 to 70 per cent of total cash recelpts recelved by the farmer. Poultry barely had a rooting in these counties.

In the tier of counties stretching southward from Fulton to Macon County and Crawford County, diversification was moderate but higher than that in the eastern Pledmont. 
Cotton had a secondary place in many of these counties and trees-peaches and pecan--dalry products, and beef cattle contributed to greater aIversification. In Upson, Crawford, and Peach counties, peaches were important enough to lead to more concentration.

Divergification in 1949 and 1939-49. The pattern of diversification in 1949 and the changes between 1939 and 1949 are shown on Maps XIX, XX, and XXI. The 1939-49 trend was toward decreasing concentration. Over three-fourths of all counties became more diversified. The mean Gini coefficient fell from .74 in 1939 to .71 in 1949, a difference significant at the 95 per cent confidence level.

A major change was the movement of the western Pledmont and western Fall Zone into the highly diversified category. All except Telfair County of the highly diversifled islands remained unchanged or gained in diversification. Telfair County moved into the category of moderate diversiflcation. This greater diversification in the western Pledmont was attributed to the increased importance of dairying, fruit, and cattle production. The region of high concentration in the eastern Piedmont was reduced to two 1slands, Madison and Walton counties. Except in these two counties, in addition to Hart and Elbert, the primacy of cotton had been successfully challenged by dairying, poultry, and other livestock 


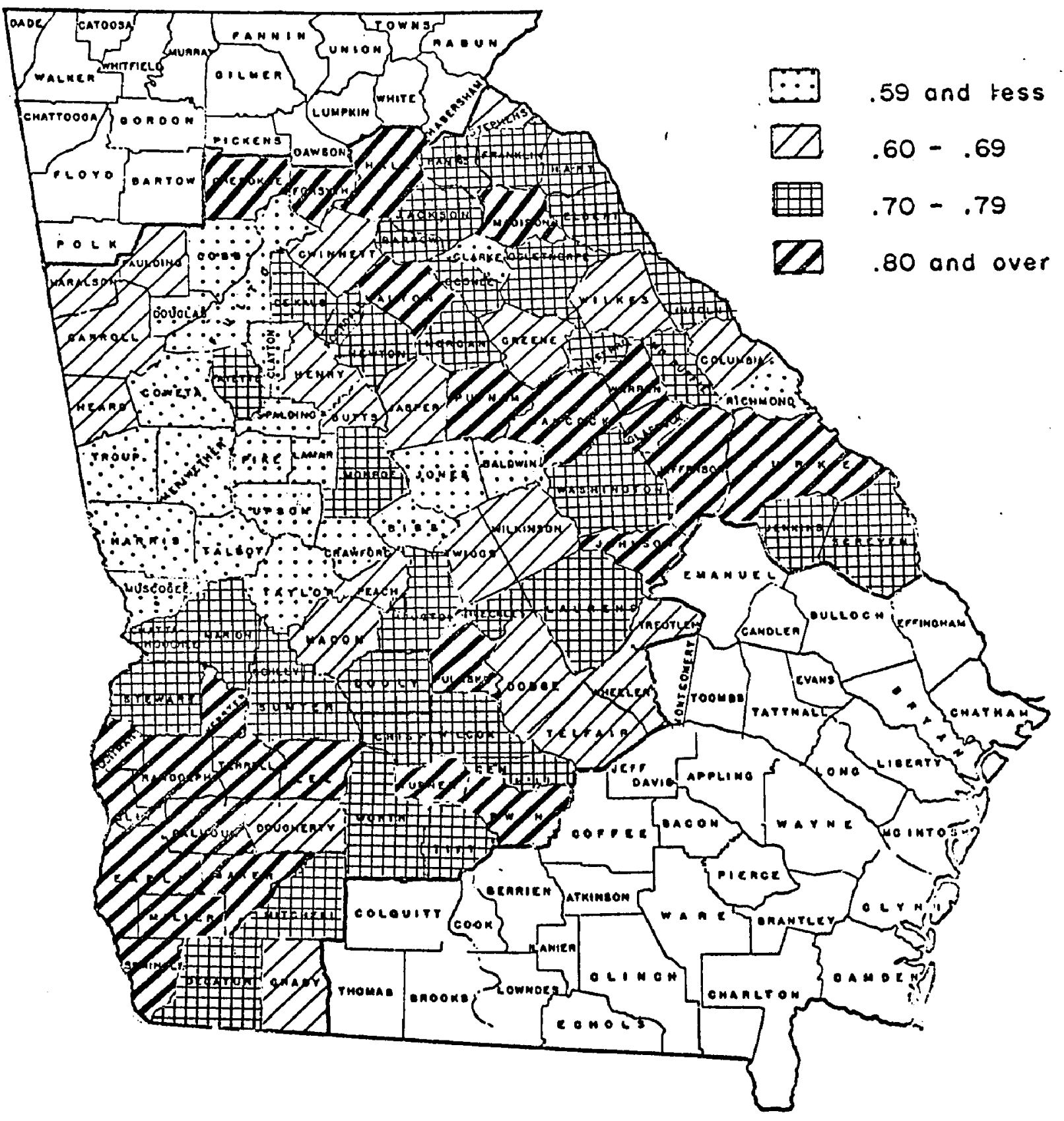

MAP $X I X$

GINI COEFFICIENTS BASED ON SALE OF FARM PRODUCTS FOR 105 GEORGIA COUNTIES, 1949 


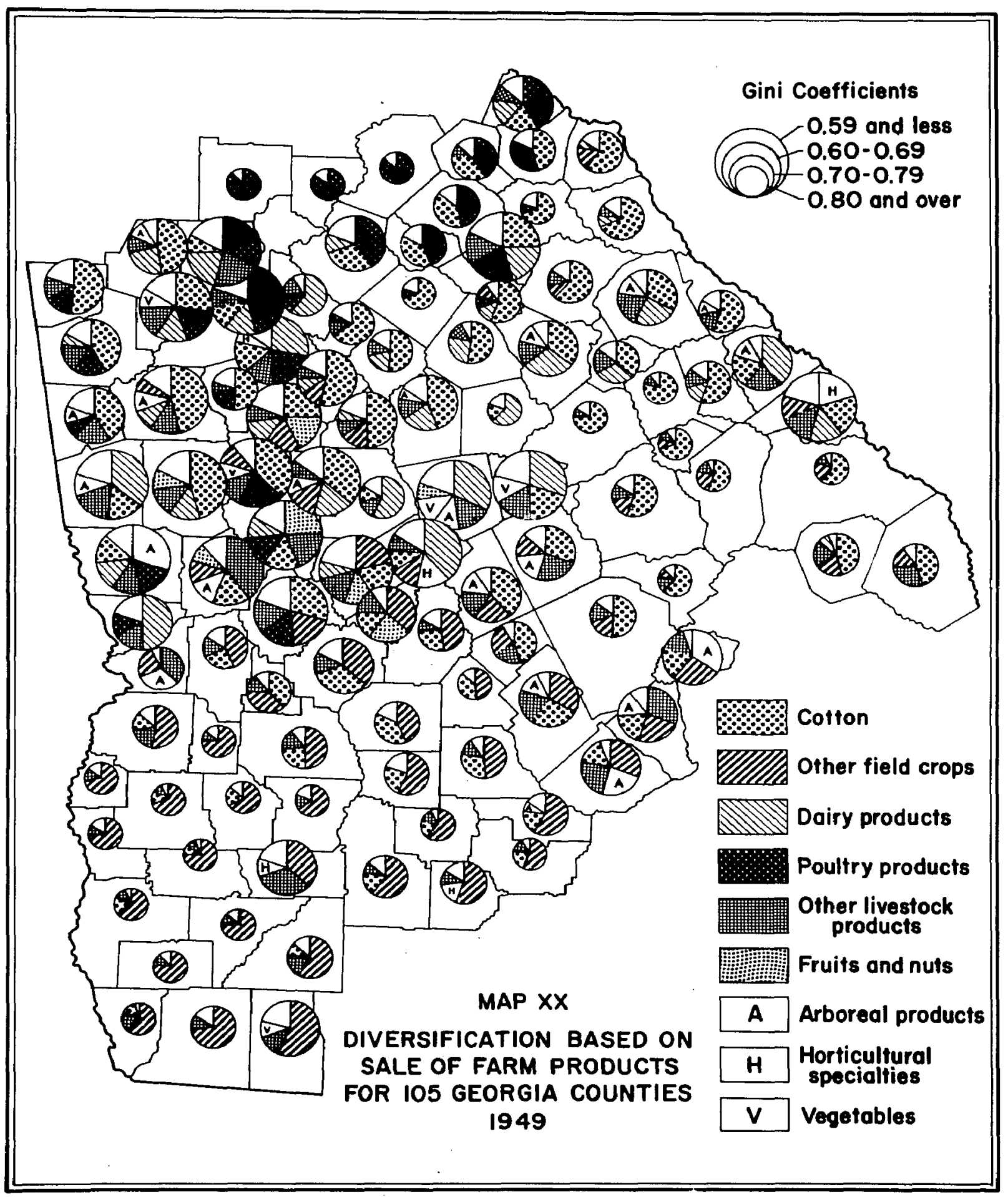




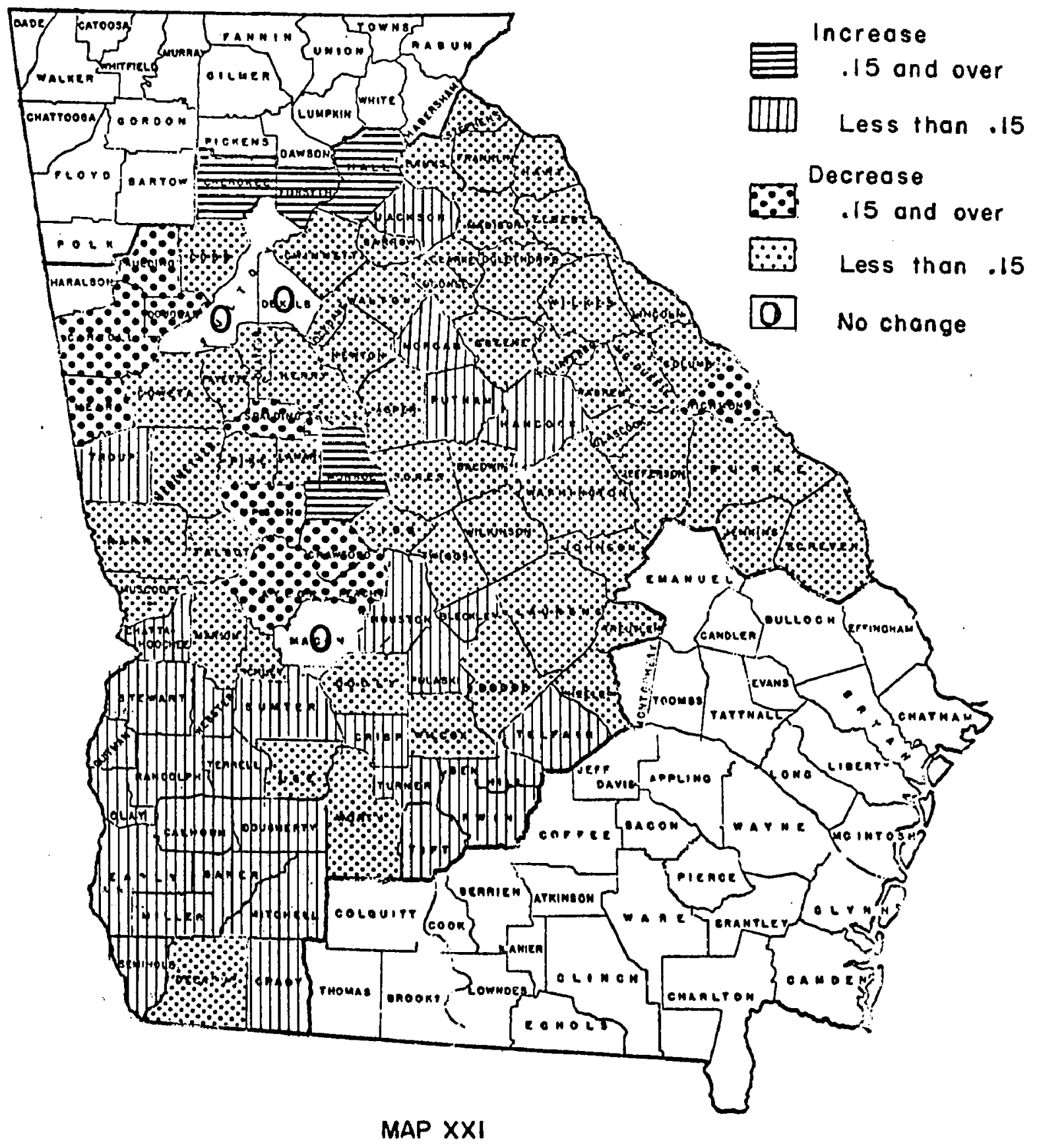

CHANGE IN GINI COEFFICIENTS BASED ON CASH RECEIPTS FOR 105 GEORGIA COUNTIES, $1939-49$ 
products. Poultry invaded this erstwhile cotton region from the north and dalrying from the south and west. Jenkins, Screven, and McDuffie countles had been removed from the highly concentrated zone of the southeastern Pledmont and eastern Coastal Plain although this second region resisted diversification more effectively than the one farther north. In these three counties Increased livestock production concomitant with the declinIng relative importance of cotton brought on the diversification.

It was noted earlier that cotton plantings were enlarged in 1949 as farmers anticipated acreage allotments for the cotton crop in the following year. This expansion was not reflected in the income structure as was the case for the acreage structure. That this expansion did not enhance the position of cotton in the income structure is a reason for arguing that the trend away from the dominance of cotton and toward animal products was a secular one only slightly influenced by acreage expansions or contractions in the traditional row crop.

The highly concentrated peanut growing area in the southwestern Coastal Plain Intensified and expanded. Perhaps this can be traced to the encouragement given peanut growers by the government during the war years, as well as relatively high prices for peanuts in 1949 as compared to 1939. Good prices and Increased production of peanuts, 
especially in SEA $7 \mathrm{~b}$, must not be overlooked. Although cotton had not been a major source of income here since the 1920 's, between 1939 and 1949 it was squeezed out of the income structure in many counties and reduced in others. This contributed to increasing concentration in the southwestern Coastal Plain.

Although the 1939-49 trend was overwhelmingly toward increasing diversification, five counties registered marked gains in concentration. They should be mentioned here because they represent trends that later spread to surrounding counties in the 1949-59 decade. Hall, Forsythe, and Cherokee counties had Gini coefficient gains of .24, .19 , and .32 , respectively. Poultry sales rose to commanding positions in these counties. They accounted for close to 90 per cent of all cash farm receipts in all three counties. Farther south in SEA 4b, Monroe and Putnam emerged as dalry strongholds. In both of these counties, the sale of dalry products represented from 60 to 65 per cent of all farm commodity sales in 1949.

Diversification in 1959 and 1949-59. In 1959, the average diversification as determined by the Gini coefficlent remained essentlally the same as the 1949 figure. See Maps XXII, XXIII, and XXIV for the 1949-59 changes and the status of diversification in 1959.

While the average Ginf coefficient was about the same in 1959 as it was in 1949, there were large shifts in 


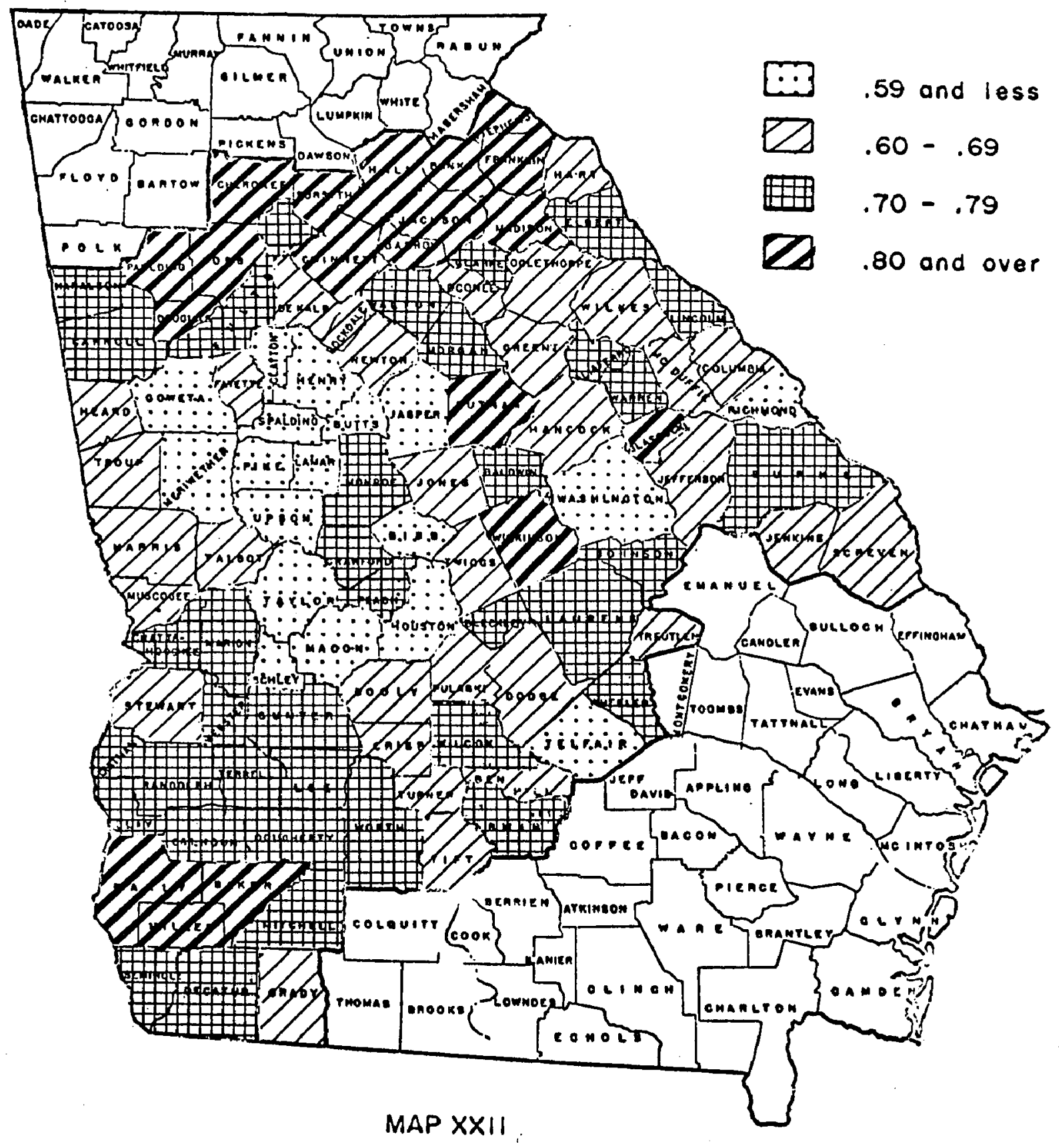

GINI COEFFICIENTS BASED ON SALE OF FARM PRODUCTS FOR 105 GEORGIA COUNTIES, 1959 


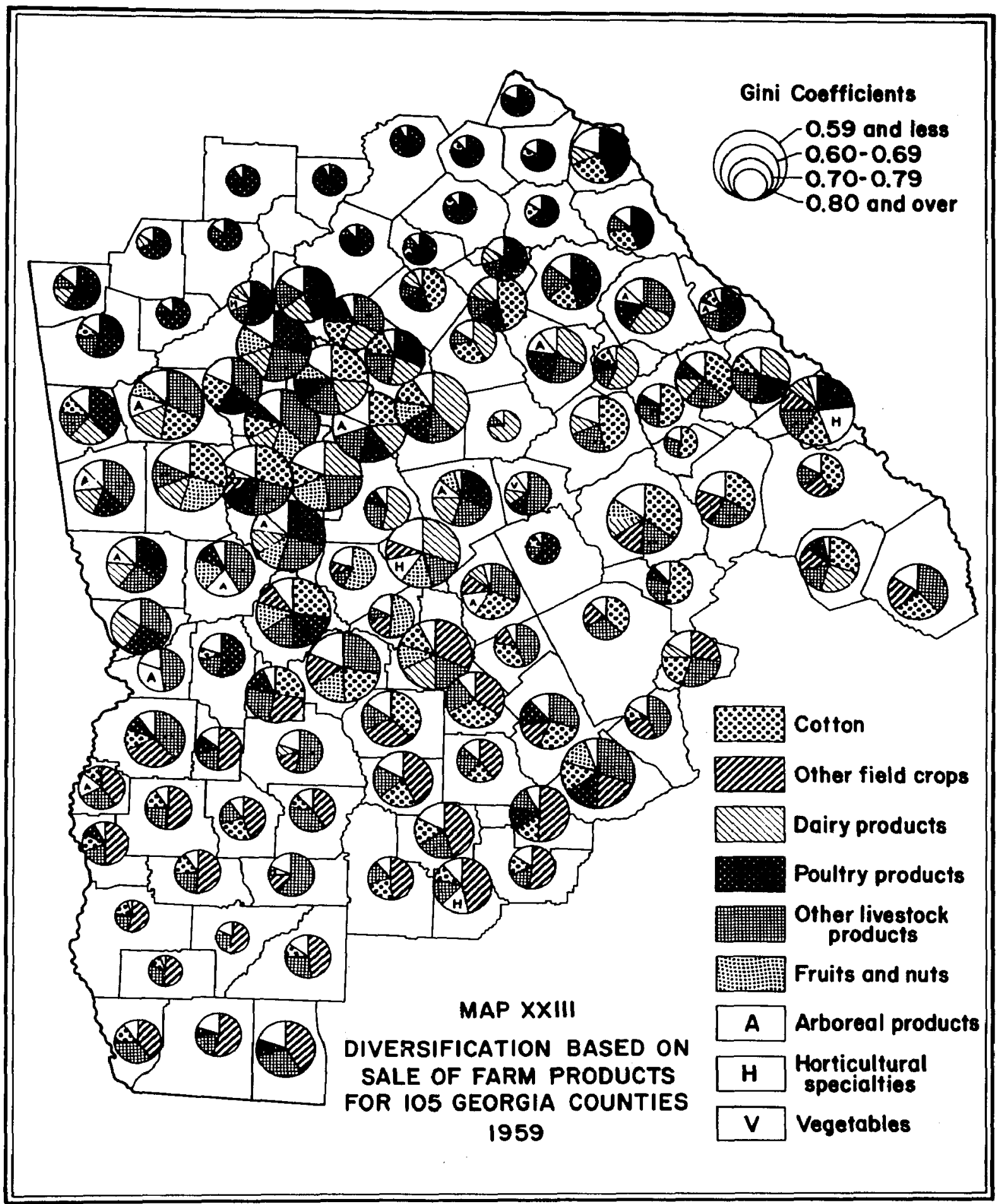




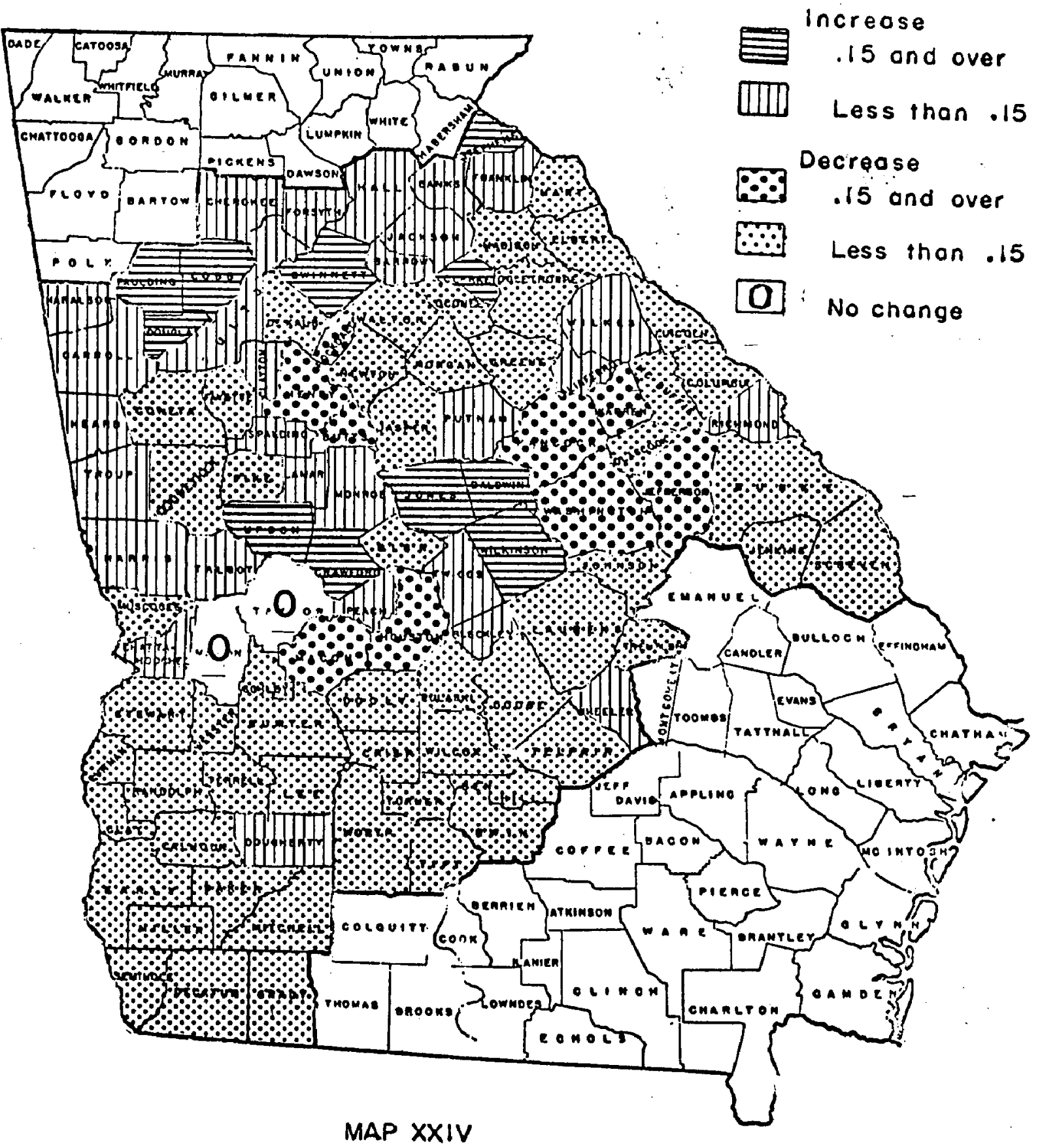

CHANGE IN GINI COEFFICIENTS BASED ON CASH RECEIPTS FOR 105 GEORGIA COUNTIES, 1949.59 
both the direction of concentration and that of diversification. In general, the Coastal Plain became more diversifled while the Pledmont vecame more concentrated. Especlally was this concentration apparent in SEA 3 and SEA $4 \mathrm{~b}$ of the Pledmont.

The three highly concentrated districts observed in 1939 based on the concentration of cotton in the north and east and peanuts in the southwest had been almost entirely dismembered. Even the fragments that remained barely retained Ginl Coefflclents large enough to keep them In this category. Glascock County with 60 per cent of its total cash farm recelpts from cotton in 1959, was one such remnant of the more diversifled zone in the southeastern Piedmont-eastern Coastal Plain. Much of the increase in diversification in this region as a whole was attributed to a relative decline in cotton and an increase in sales of Ilvestock products. The expansion of dafrying, which first appeared in the income structure in 1949, continued. Poultry made gains in several countles and frult appeared in the income plcture for Washington County.

Early, Baker, and Miller counties were remnants of the much larger highly concentrated district in the southwestern Coastal Plain. The relative importance of fleld crops, especially those other than cotton, declined at the expense of hog sales and the increasing importance of poultry. 
In 1959, a new highly concentrated zone emerged in the northern Pledmont in SEA 3. Only five counties in SEA 3 falled to attain Ginl coefficlents high enough to qualify for this category: Haralson, Heard, Carroll, Fulton, and DeKalb. ThIs region is clearly a "Poultry Belt" if the proportion of sales from poultry and poultry products is used as the criterion. The proportion of sales from these products ranged from 70 to 90 per cent of all cash farm recelpts in all of the highly concentrated counties and over one-half of total cash farm recelpts in all counties in SEA 3 except Heard and DeKalb. Poultry production is by no means concentrated in this area, but it has spread southward even into the Coastal Plain. The trend toward diversification throughout most of SEA $4 a$ was accomplished through a rise in the percentage of poultry sales. Brollers accounted for the largest percentage of these poultry sales.

The growth of the broller industry was a response to an expansion of the demand for this product in the United States as well as abroad. The initial impetus came during the war years of the 1940 's when other meats were relatively scarce. Being labor extensive and capital intensive, it seemed to have fitted well into the secular trend of American agriculture. Prices rose during the 1940's and reached a maximum in 1948. In 1959, the average broller price was 16 cents per pound compared with 36 cents a pound 
In 1948. Nevertheless, the trend in production and consumption has been upward since the second World War. 9 Georgia is the leading producer in the nation. Another observation of the 1959 situation was that the western Pledmont, especially SEA $4 \mathrm{a}$ and SEA 4b, retalned its highly diversifled character in spite of strong trends toward concentration in a few counties. By 1959, the role of cotton in the income structure had been decldedly weakened. Cotton was the leading crop only in Pike, Merlwether, and Taylor counties. In one-half of the highly diversified counties it was forced out of the income structure altogether. Beef cattle, poultry, and dalry products had taken the place of cotton. Sales of peaches In Taylor and Talbot counties and of pecans in Lamar County had grown enough for these products to enter into the income structures of these counties. Cash recelpts from forest product sales expanded absolutely and either Improved or maintained their 1949 positions in the income picture. According to Prunty, much of this expansion in forestry resulted from upgrading old stands through restocking and reseeding. Such activities were encouraged by demands of

9Agricultural Statistics, 1962, United States Department of Agriculture (Washington: U.'S. Government Printing Office, 1963), p. 489 . 
pulp-paper mills which have been on the uprise in the south. 10 Pines are the most prevalent species. No "Da1ry Belt" comparable to the "Poultry Belt" farther north could be said to have existed in Georgla in 1959. However, a group of counties in the central Pledmont--Monroe, Putnam, Morgan, Jasper, and Newton--appeared to have been moving toward that status. These flve counties accounted for almost a fifth of the 2,319 dalry farms in the state in 1959 and ajmost as large a proportion of total sales of dairy products for the state. The position of dairy products had been rather flrmly established in the Income structures of Putnam and Monroe counties as early as 1939 and was maintained for the 1939-59 per1od. However, It was not until 1959 that dalry products displaced cotton from the number one position in Newton, Jasper, and Morgan counties. In first place in 1949, cotton had not only lost this position in these three counties by 1959, but the expansion of dairying had been great enough to effect a concentration of dairy products almost equal to that of cotton a decade before.

The profiles of changes in diversification based on cash farm recelpts presented in Map XXV summarize the trends for the 1939-49 and 1949-59 decades. This map reveals a

10 Merle S. Prunty, Jr., "The Woodland Plantation as a Contemporary Oocupance Type in the South," Geographical Review, LV (January, 1963), p. 19. 
Change in Diversification

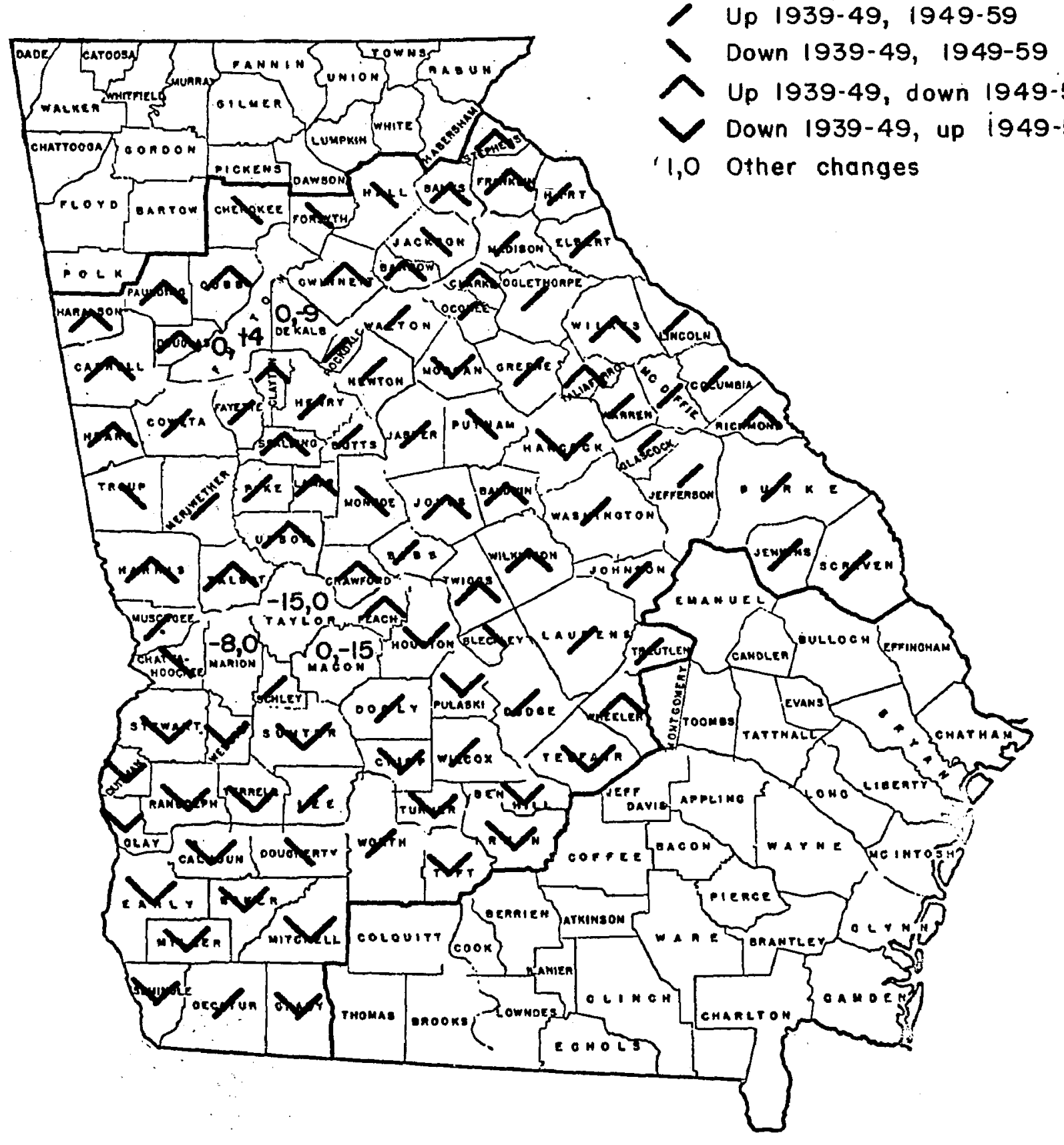

MAP XXV

PROFILES OF CHANGES IN INCOME DIVERSIFICATION FOR IO5 GEORGIA COUNTIES, 1939-49 AND 1949-59 
weak regionalsty assoclated with various crop and Iivestock combinations and non-agricultural factors as well. There were four eategories into which most of these profiles fell: (1) a trend toward concentration for both decades (symbol $=\backslash) ;(2)$ a trend toward diversiflcation in the first decade and toward concentration in the second (symbol $=\wedge) ;(3)$ a trend toward diversification in both decades (symbol $=/)$; and (4) a trend toward concentration In the first decade and toward diversification in the second $($ symbol $=v)$. Some of the conclusions are presented below.

First, the southwestern Coastal Plain had a preponderance of $v$-shaped profiles. The greater concentration in the 1939-49 decade was brought on by the peanut expansion. In the 1949-59 decade, the growth of livestock production-hogs and poultry, mainly--tended to increase the diversification.

Second, in the southeastern Pledmont-eastern Coastal Plain and the eastern Pledmont, especially in SEA $4 a$, the two regions where cotton had held the commanding position In 1939, the trend was toward increasing diversification for both decades. Much of this was due to the slowness of cotton being removed from the income structure.

Third, the western Pledmont had the $\wedge$-shaped profile in most counties. The 1939-49 increase in diversification was associated with the expansion of secondary and tertiary 
products and the contraction of cotton in the income structure. Concentration in the following decade was attributed to a marked expansion of livestock and livestock products. Fourth, in the central part of the northern Pledmont, the trend was for concentration in both decades. These were the core counties of the "Poultry Belt."

Fifth, there was no consistent pattern for all the urbanized counties. Nevertheless, most of them seemed to differ from the surrounding counties.

S1xth, and finally, several zones emerged as transitional. The central coastal Plain and central Pledmont are examples. In the coastal Plain, the cotton area on the east was connected by this zone with the peanut region on the west. The transition in the pledmont is more complex but is related to the competition between cotton, on one hand, and livestock, fruit, and forests, on the other. 


\section{EVALUATION OF HYPOTHESES}

This chapter deals with the second and third objectives that were set forth in the Introduction. The second objective is to test the validity of the hypothesis that the trend toward diversification has been weaker in certain core cotton-producing regions, as delimited by Prunty, than in other areas of the state. Immediately following, in the first part of this chapter, these core areas are identifled on a basis of the criterion used by Prunty. This 1s followed by a presentation of evidence needed to ascertain the validity of this hypothesis. The third objective is the evaluation of the hypothesis that there are stages of diversification through which the state has passed that could be Identified. The second section of this chapter presents the evidence used to support or reject this hypothesis. It is logical to have this chapter follow the analysis of diversification made in Chapter III because the latter provides a background for the evaluation of these hypotheses.

The first hypothes 18

The first hypothesis stated that the trend toward diversification has been weaker in the core cotton-producing 
regions than in other sections of the state. These core cotton-producing regions were delimited by Prunty for 1944 data on a basis of having 8.5 per cent of the total area of county planted to cotton. The suggestion of this hypothesis arises from an argument advanced by Prunty that these core cotton areas were destined by inherent advantages to retain their cotton culture characteristics for many years. It was his assumption that cotton would remain a leading crop In terms of both acreage and income. 1

Such an assumption seemed justifled in light of statements from Bogue and Beale in their description of the state economlc areas noted in Chapter II. They pointed out that In SEA's $4 a$ and 6 cotton culture persisted with greater tenacity than in other areas of the state. These economic areas were nearly coterminous with Prunty's core cottonproducing regions.

The northernmost core cotton-producing countles, delimited on a basis of the Prunty criterion using 1944 data, lay in the Pledmont, mainly in SEA 4a (Map XXVI). The counties meeting the criterion were as follows: Frankin, Hart, Madison, Jackson, Barrow, Oconee, Walton, Morgan, Newton, Henry, Fayette, Butts, P1ke, Jackson, and Carroll. Elbert County in SEA $4 \mathrm{a}$ barely missed being included and Oglethorpe County had three-fifths of the required cotton

\footnotetext{
${ }^{I}$ see the Introduction.
} 


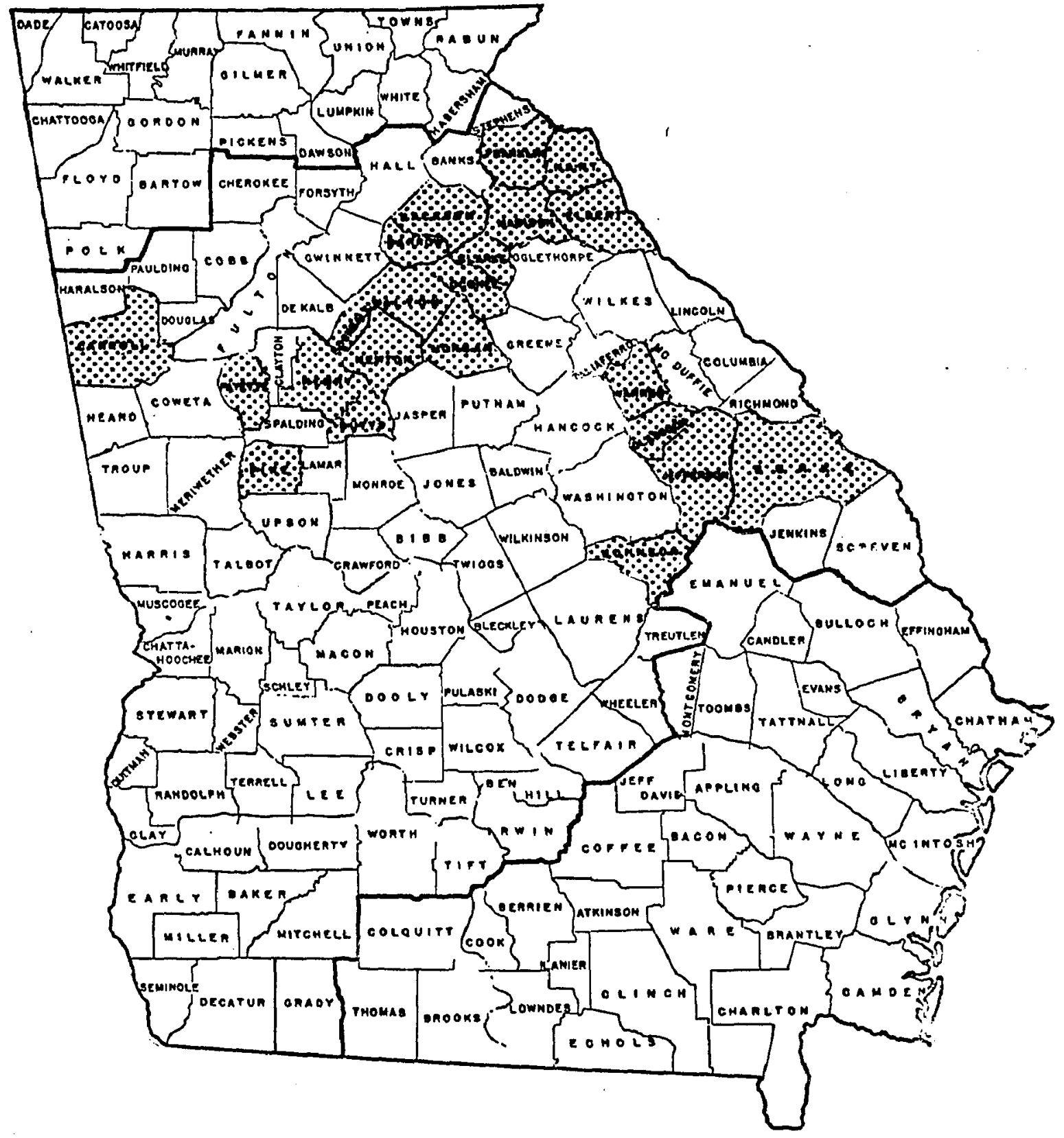

MAP XXVI

CORE COTTON-PRODUCING COUNTIES, GEORGIA, 1944 
acreage. Carroll County, not being cont1guous to the other counties, was excluded from the analysis, while Elbert County was Included.

Five other counties lying in the southeastern Pledmont and northeastern Coastal Plain qualified for the designation of core cotton-producing counties. They constituted the second core cotton-producing region. They were Warren, Glascock, Jefferson, Burke, and Johnson. McDuffie had almost enough cotton planted to qualify. Hancock and Washington counties had large absolute acreages in cotton and large amounts in comparison to total cropland, but because of their large size, they did not qualify when the cotton acreage was measured against the total land area.

The presentation of data needed to evaluate the validity of this hypothesis is divided 1nto three cases, each of which is discussed separately below. In the following discussion the use of the term region in no way implies that data have been collected or analyzed for any areal unit other than the county. The region denotes a group of counties which are similar in the amount of diversification and the type of products comprising the land use or income structures. Simliarly, the state values are summarized from the county data.

Case I. In the first case, the hypothesis was that the trend toward diversification based on land use has been weaker In the core cotton-producing region of the central pledmont 
than in the remainder of the state. The hypothesis that the core cotton region of the central pledmont was less diversifled than the remainder of the state was rejected. The level of refection was higher for 1939 and 1949 than for 1959. The fact is that the core cotton counties were more diversified than the rest of the state as a whole, especially in 1939. In this year nine of the fifteen core cotton counties of the Pledmont had Gini coefflclents of .50 or 1ess. The average coefficient for the state was .58. Furthermore cotton was the second ranking crop in all counties in this core region except Franklin, Hart, and Jackson, while corn was the leadIng crop.

By 1949, most of this core region had become more diversifled, although the 1949 mean GInI Coefficlent was unchanged from that of 1939. The leading crop was cotton, which had displaced corn for number one rank. Explanations for this relative expansion of cotton production have already been offered.

In 1959, the trend toward increasing diversification was reversed in several core cotton counties as only flve of the fifteen core cotton counties became more diversified. of those that became more concentrated, Fayette, Butts, PIke, and Newton, had gains in Ginl coefficlents of at least .09 points. By now cottion had become a minor member of a complex where pasture was the foremost type of land use. Case II. In the second case, the hypothesis is that the trend toward diversification based on land use has been weaker 
In the core cotton-growing region of the northeast Coastal Plain than in other sections of the state. The hypothesis is accepted with qualification.

Because only five counties were involved, the use of statistical techniques to answer the question was unfeasible. But it was concluded that in 1939, this area was in general more concentrated than the remainder of the state and in particular the Pledmont. The average Gini coefficient was .63 for the five counties while for the state as a whole it was .578 in 1939. Ginl values for all five counties were at least as large as the state average. Nevertheless, the . southwestern coastal plain was much more concentrated. A corn-cotton-cowpeas combination best describes the acreage structure. Corn was the leading crop rather than cotton. The pattern of change 1939-49 and 1949-1959 was toward more diversification. By 1959, all five counties had lower aini coefficlents than they had in 1939. The extreme case was Jefferson County where the coefficient fell from .61 in 1939 to .55 In 1949 and to .38 in 1959. Jefferson County had a five cropscombination of corn, cotton, pasture, cowpeas and oats in 1959.

The conclusion then is that the hypothesis that the second core cotton-producing region was more concentrated than the state as a whole must be rejected for 1949 and 1959 but accepted for 1939. 
Case III. In the third case, the hypothesis is that the trend toward diversiflcation, based on source of income from the sale of farm products, has been weaker in the core cotton-growing region of the central pledmont, as well as the northeastern Coastal Plain, than in other sections of the state. Th1s hypothes1s was accepted for 1939, but elther refected or accepted with reservations for succeeding years.

Both core cotton-producing reglons were more concentrated than the state as a whole in 1939. The three h1ghly concentrated areas vividly portrayed on Map XI have already been discussed. The two easternmost of these three concentrated areas nearly colncided with the core cotton-producting regions.

In 1939, elght of the 15 core cotton counties of the Pledmont had Gini coefficlents in excess of .80 and all except one had values greater than .70 . The average Gin1 coefficient for these 15 counties was .81 compared with .74 for the state as a whole. This difference in means was significant at the one per cent level. In the core cotton area to the south including Warren, Glascock, Jefferson, Burke and Johnson counties, all five counties had Gini coefficients greater than the average for the state. In fact, their mean GInI coefficient was .87 compared with .74 for the state.

By 1949, however, the mean GIni coefficlent for the Pledmont core cotton counties was only .03 units above the 
average for the state and in 1959 the two means were within .02 polnts of each other. These differences in mean could be attributed to random error. A majority of these 15 counties became more diversified in both the 1939-1949 decade and 1949-59 decade. The validity of the hypothes1s could not be sustained for 1949 and 1959 .

For the five core cotton-producing counties of the Pledmont-Coastal Plain the relatively greater concentration persisted for a longer time. In 1949, all of the five countles maintained Ginf coefflclents of at least .80, or roughly .10 points above the mean coefficient for the state. By 1959, however, the mean Gini coefficient in the five counties dropped to within .03 points of the state mean coefficient, a difference that could hardly be significant. Hence, the hypothesis is rejected for 1959 and accepted for 1939 and 1949 for the second core cotton area.

The assumption that cotton was dominant in the income structure and hence responsible for the greater concentration In the core cotton-producing counties was confirmed. Greater diversification accompanied the displacement of cotton in the income structure. The products that were responsible for this displacement--11vestock products, frults, nuts, and forest products--have already been discussed.

The greater validity of this first hypothesis for diversification based on income is instructive. It points up the fact that the relative expansion of acreage not planted 
to cotton was for uses less efficient than cotton as money earners on a dollar per acre basis. Wheat, oats, grasses, and cowpeas are good examples of such low-yleld crops. A coroliary of this had been the extension of capital intensive production where little land is required. Poultry and dairy enterprises are cases in point. However relatively few farmers have capital resources for these latter ventures.

The second hypothesis

The third task of this thes 1s was to test the validity of the hypothesis that there were stages of diversification through which the areas under investigation had passed. It was felt that an analysis of the three years--1939, 1949, and 1959--should provide some bas1s for doing th1s. In the first instance and 1mmediately following, the hypothetical stages of the model are discussed. Th1s is followed by a consideration of the case of land use diversiflcation and then the case of income diversification.

Hypothet1cal atages of the model. Stage I (Chart I) was concelved of as having a maximum concentration of cotton in the county land use structures. Th1s existed in the 1930's and earlier when Georg1a, like the rest of the Cotton Belt, had a large percentage of its cropland in cotton. Corn, of course, was important and often vied with cotton for first place. The two crops together accounted for from 70 to 80 per cent of the cropland even in the heyday of cotton production. In the income structure, however, the concentration of 


\section{CHART I}

\section{GRAPHIC SCHEMA OF DIVERSIFICATION}

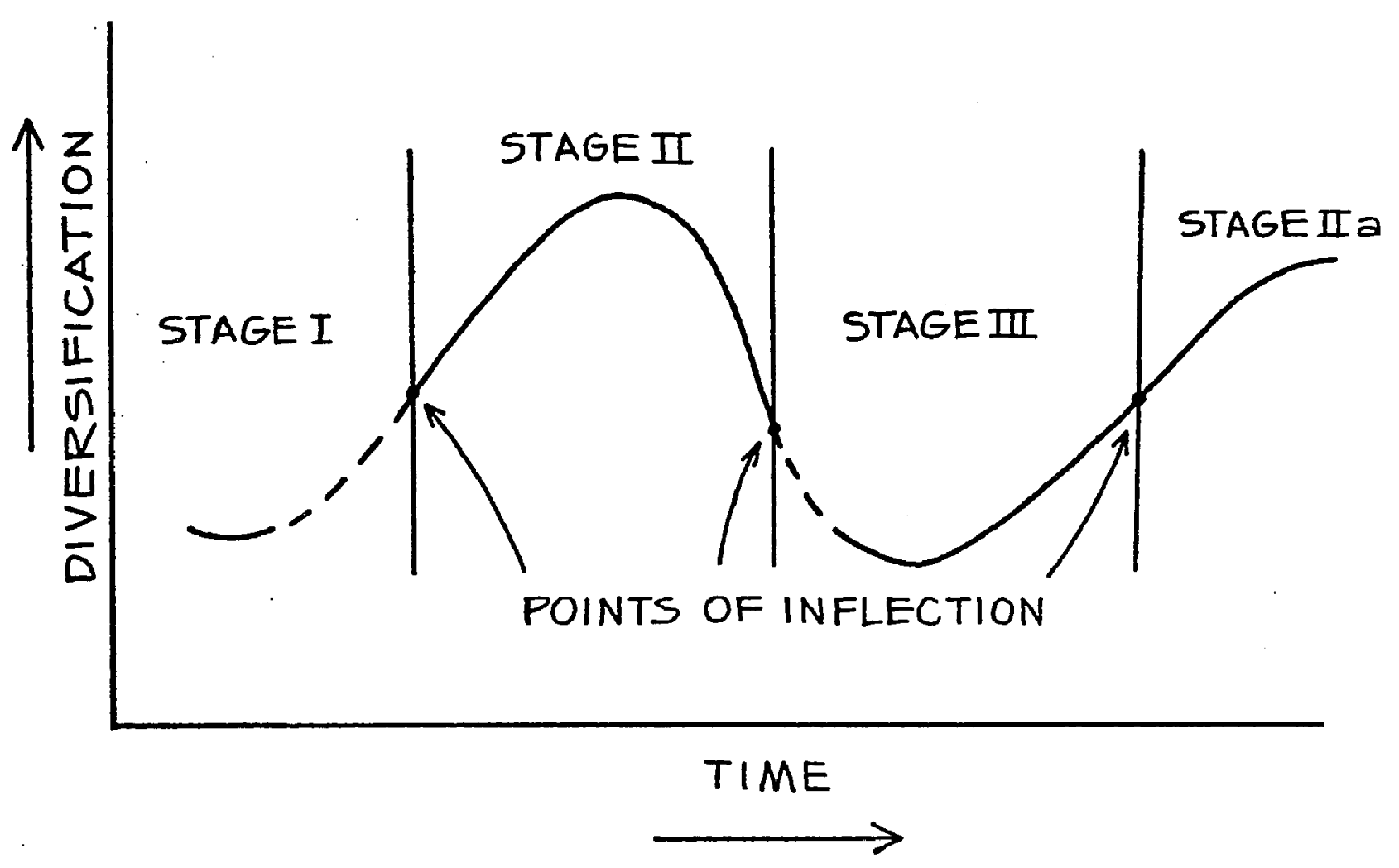


cotton was sufficlent to classify the state as monocultural. Rising living standards, higher incomes, and growing urbanization were resulting in changes in the kind of products demanded from farmers. The demand for 11vestock products, fresh fruits, and vegetables was growing. New demands for paper products, fresh fruits, and vegetables expanded. Moreover, surpluses of cotton were accumulating in this country as secular domestic demand declined and exports dwindled. It seemed logical to assume that shifts in demand would result in the extension of land uses to supply these new demands. Under such conditions cotton, and to a smaller extent peanuts and tobacco, would become relatively less significant in the county structures.

The emergence and expansion of the new land uses would lead to Stage II as more farmers would devote more land to the newer land uses. Maximum diversification would occur in this stage. No clear cut boundary is placed between maximum diversification of Stage II and maximum concentration of Stage I. Such a boundary could well be an inflection point where Increasing slope gives way to decreasing slope on the diversification curve in a more sophisticated study where diversification is rigorously defined as a function of time.

Stage III is reached when increasing concentration brings a minimum of diversification. The concentration of the new commodity or land use results from a kind of quasiequilibrium in which this new product or land use acquires 
a competitive advantage over others in light of new demands and production costs. In a sense, this is Stage I again, but with a new product. To project this ideal construct farther along a time sequence would bring out its repetitive or cyclic nature which also has certain intrinsic implications for the geographer.

Identification of stages in land use diversification. The question now asked is whether there is any validity in such a hypothesis that can be substantiated by data from this study. The problem of determining if there are stages of diversification cannot be divorced entirely from the one of ascertaining the stage of some given point in time for which data are avaliable. At the beginning, the case for the state as a whole w1ll be consldered. Th1s will be followed by a regional analysis of the problem: Land use diversification will be dealt with first.

In the following discussion where the state as a unt is considered in 1dentifying the stages of diversification, the averages and other stat1st1cal measures were computed from the aini coefficients of the individual counties. Caution should be exercised in not interpreting these statistical measures to imply uniform distribution of these values over the state. For example, a moderate average Gin1 coefficient may result from both extremes of concentration and of diversification in different parts of the state at 
the same time. The main advantage in these statistical measures lies in their utility as norms to which the separate regions of the state may be referred in subsequent discussions.

The procedure for determining the stage in wh1ch 1939, 1949, and 1959 fell started with ascertaining if 1939 was In Stage $I$ and then finding if the succeeding years belonged to this same stage or a different one. Such a procedure seemed justifiable since it was assumed that diversification moves along some continuum with time.

Then the first question was to ask if diversification in 1939 warranted placing this year in Stage I. The answer offered here was no. In the first place the average Gini coefficient was only .578 , a value that is intermediate between the extremes of one and zero, representing maximum concentration on one hand and maximum diversification on the other. Some three-fifths of the 105 counties in 1939 were more diversifled than this mean. In the second place there was no concentration based on cotton in the acreage structure. Chart II leads one to think that maximum concentration would have been more likely in 1929, when the cropland used for corn and cotton was roughly equal. Moreover, only three of the counties had cotton in the rank one pos1tion in 1939. The tendency toward greater concentration in most of the other counties was the effect of the primacy of corn in the land use combination. Clearly, the state of 
diversification of 1939 did not fit the 1deal construct for Stage I. Hence it was assumed that 1949 and 1959 were also In a more advanced stage.

Could the 1939 state of diversiflcation have belonged to Stage II? The argument is for an affirmative answer. From the Indications above the position of cotton had fallen and was relatively low in comparison to what it most likely was in prior decades. Moreover, other land uses had gained a foothold. In over one-half of the 105 countles, there were at least four land uses in the crop structure. A majority of the remaining counties had three way land use combinations. Only in the southwest peanut growing region did two-crop combinations occur. The argument that the 1939 diversification stage may have belonged to stage III was refected because of only moderate concentration in relation to what was to occur in later years.

The next logical query was whether the 1949 data qualIfled for Stage II or Stage III. The answer selected here 1s Stage II. In the first place the average Gini coefficient was virtualiy the same in 1949 as it was in 1939. Even the frequency distributions for the two years were similar. See Table 2 below. In addition, Chart II suggested more diversification in 1949 than in 1939. This lent additional support to the argument that the diversification status of 1949 was no further advanced than Stage II. This chart showed that a relatively large reduction in the corn acreage had 


\section{CHART II}

LAND USE IN GEORGIA, 1929-59

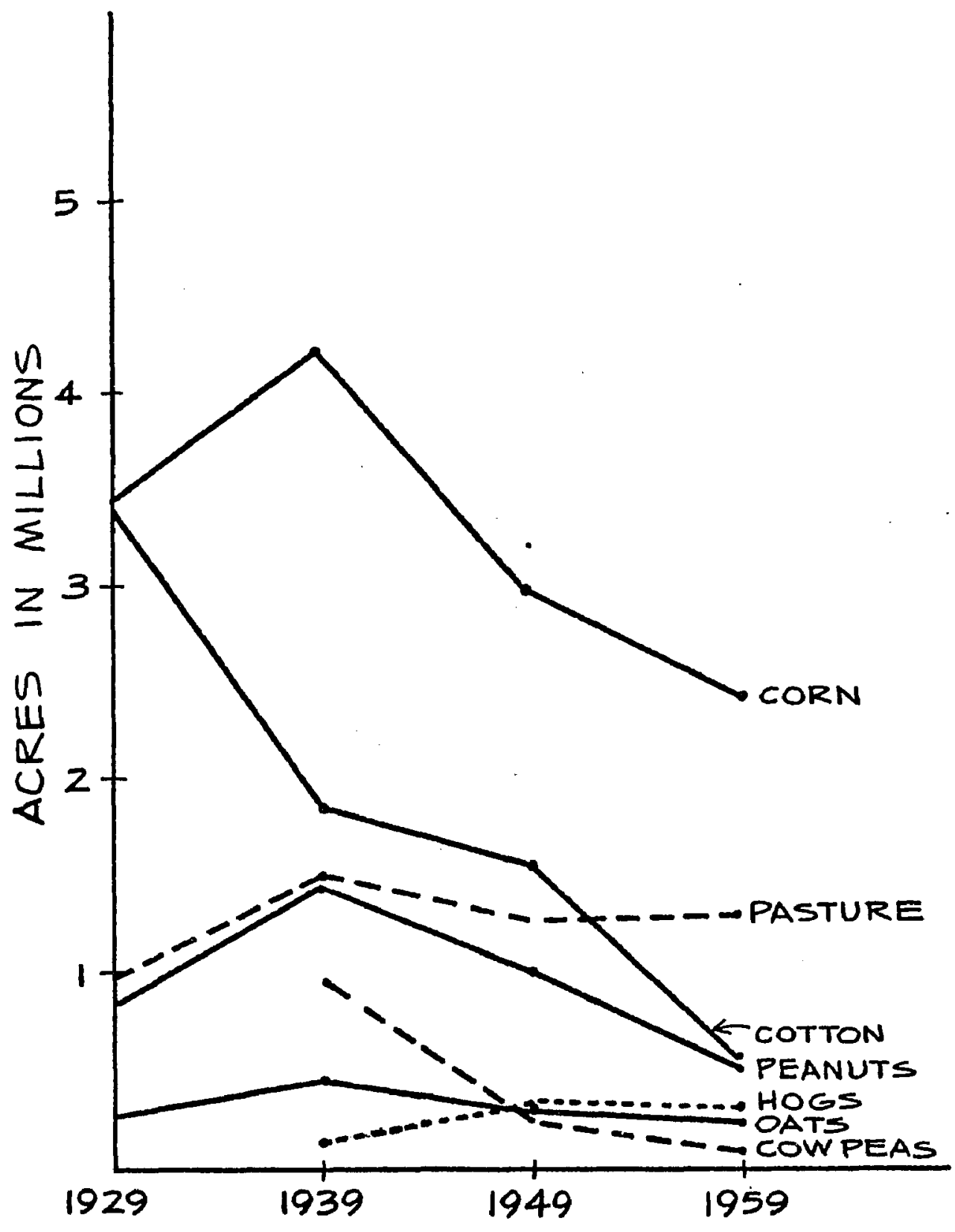


TABLE 2

FREQUENCY DISTRIBUTION OF GINI COEFFICIENTS

OF LAND USE DIVERSIFICATION, 1939, 1949 and 1959

\begin{tabular}{cccc}
\hline Gini Coefficient & $\begin{array}{c}1939 \\
f\end{array}$ & $\begin{array}{c}1949 \\
f\end{array}$ & $\begin{array}{c}1959 \\
f\end{array}$ \\
\hline $.80-.89$ & 0 & 0 & 2 \\
$.70-.79$ & 8 & 9 & 15 \\
$.60-.69$ & 32 & 36 & 39 \\
$.50-.59$ & 45 & 39 & 30 \\
$.40-.49$ & 17 & 16 & 12 \\
$.30-.39$ & 3 & 5 & 7 \\
\hline Means & $\mathrm{N}=105$ & $\mathrm{~N}=105$ & $\mathrm{~N}=105$ \\
\hline
\end{tabular}

brought the acreage planted to corn and cotton more nearly equal in 1949. This meant the strengthening of the position of cotton in the acreage structure, especially in the Pledmont. By 1949, 15 counties ranked cotton first and all but one of these were located in the Pledmont. Somewhat paradoxically, however, this enhancement of the position of cotton contributed to more diversification in most of these 15 counties as well as in others. On the other hand, the expansion of peanut production relative to other land uses In the southwest Coastal Plain contributed to an increase in concentration in a few counties.

W1th 1939 and 1949 placed in Stage II, the question now is whether 1959 should be placed in the same stage or in 
Stage III. In order that 1959 qual1fy for Stage III, 1t was necessary to show that a maximum of diversification had been reached before this year and that the trend around 1959 would be toward increasing concentration of some crop other than cotton in the land use combination. Because of the difficulty of rigorously proving that such was the case and on a basis of the fact presented below, 1t was concluded that diversification in 1959 was a border case entering Stage III.

Table 2 is of almost no use in solving this problem. It shows that the average Ginl coefficient for 1959 was only .02 points above that for 1949. This difference was not significant at the five per cent level. A Ch1 square test of the difference between the two frequency distributions and significance tests of differences between selected proportions all tended to show that the two distributions were not significantiy different. An examination of the data on Chart II for 1959 suggests an even greater amount of diversification this year than in 1949 as a result of the increased importance of pastured cropland.

However, an examination of Map XV reveals that a trend toward concentration was extensive in the Pledmont and fairly strong in a few counties in the Coastal Plain. Over two-thirds of the counties in the Pledmont became more concentrated. While a smaller fraction of counties became more concentrated in the Coastal Plain, the weak trend toward diversification in the remainder resulted in 
a small net change. Apparently maximum diversification had been reached for the large number of pledmont counties that had become decidediy more concentrated as a result of the expansion of pasture and the weakening of secondary crops. On the other hand this cannot be said for a few counties in the northwest Pledmont that became more diversified in the 1949-59 decade than the previous one. It does seem un11kely that they w11l become more diversifled from 1959-69. Some basic shifts in combinations of land use from 1949-59 seemed to point toward increasing concentration of land uses other than cotton. By 1959 only three counties had cotton in the highest ranking position while pastured cropland occupled a dominant position in four-fifths of the Pledmont counties, displacing cotton and corn for this distinction. I In one-third of the Pledmont counties pastured cropland occupled over one-half of the total cropland. In the Coastal plain, this shift in land use was less marked. Here first ranking land uses were for corn and rarely for pasture or peanuts. The latter crop had first rank position In several counties in 1949, but had been displaced by corn in this rank in 1959.

The shift to more concentration through pastureland seemed to suggest that Stage III was reached in 1959 while

${ }^{1}$ In 1949 , pasture was first place in only about onetenth of the piedmont counties. 
an analysis of the Ginl coefficlents seemed to lead to the conclusion of no significance between the 1949 and 1959 data. Since 1t was pointed out above that not all parts of the state had progressed to the same stage, it was found instructive to look at each region separately. Because of the small number of units in each region, no statistical analyses were used.

In general, all the Pledmont except the easternmost counties appeared to have been further advanced than other parts of the state in terms of the stages. The dominance of pasture, and the prevalence of hay and grain, along with an emphatic trend toward concentration in 1939-59, warranted placing most of the Pledmont in Stage III in 1959. Increases In the Gin1 coefficient both in the 1949-59 decade and the 1939-59 period had produced high or moderate concentration In a majority of the counties here by 1959. Furthermore, these changes were associated with the rise in the prominence of livestock, especialiy poultry, as was pointed out earlier. Under the expansion of the Atlanta metropolitan area and other urban centers, new supplies of milk and meat were demanded. Th1s part of the state had witnessed larger increases in part time farming which had been related to the growth of non-farm employment opportunities.

On the other hand, the northeast Pledmont and the Southeast Pledmont-east Coastal Plain were apparently in stage II in 1959. These counties contained most of the core 
cotton-producing regions described earlier. In the 1949-59 decade, they were still becoming more diversifled. If the maximum diversification had been reached in 1959--and there was no way of lmowing this by setting the upper limit of this study to 1959--certainly, 1t had not been passed. Th1s lag in the advancement of the core cotton regions was a significant finding. InItially it was assumed that the nature of the lag of the core cotton counties would take the form of higher concentration based on cotton. Th1s hypothesis was rejected. However, the more dynamic approach involving stages of diversification seemed to make the manifestation of this lag apparent. There are indications that the northeast Pledmont and southeast Pledmont-eastern Coastal Plain will not become more concentrated until cotton comes to play a less significant role in their acreage and income structures.

In those parts of the Coastal Plain where peanuts were most dominant, data for 1929 were utilized in determining the stages of diversification.

Diversification patterns for 17 counties in the extreme southwest Coastal Plain were studied for 1929, 1939, 1949, and 1959. The following sequence of events seemed to have occurred. In 1929, corn and cotton were in the leading position, with about equal frequency in nearly all of the 
17 counties. Peanuts were in second and third place as a rule. The modal Ginl coefficlent was in the .50-.59 range. Apparently, the expansion of peanuts in the 1920 's had not been sufficient, as of 1929, to displace cotton from 1ts commanding position. Th1s year was close to the time of maximum diversification if it was not the year itself. The corn-cotton-peanut combination was characteristic of the 1929 state of diversification. Th1s state corresponded to the Ideal construct of Stage II.

By 1939, the position of peanuts had improved to the point that they became a typical second place crop. This enhancement of the role of peanuts continued unt1l 1949 when over one-half of these southwest countles became highly or moderately concentrated with peanuts ranked first. Since there was a trend toward diversification in the 194959 decade, it seemed logical to conclude that a maximum concentration based on peanuts had been reached by 1949. That is to say, that the southwest had moved into stage III by 1949. Peanuts had displaced cotton.

If such was the case, in what stage of diversification was the Southwest in 1959? Map XIV precludes placing 1959 in Stage III because peanuts had become a second place crop while corn moved to first place. Moreover, moderate diversification had become more extensive. Many counties acquired a third land use in the acreage structure although 
their Ginl coefficlent remained unchanged or increased. The evidence indicated that a repetition of the entire cycle of stages was being entered. The southwest was moving into "Stage IIa."

The hypothesis that there are 1dentiflable stages of land use diversification through which the state or parts of the state have passed was accepted. Th1s stage progression was more obvious in some parts of the state than in others and the reglonal analysis was especially instructive. The conclusion reached was that the state as a whole was in Stage II In 1939 and 1949 and was entering Stage III in 1959. Identification of stages in income diversification. In the following section the question discussed is whether the state or parts of 1 t had passed through stages of diversification based upon the value of farm products sold. The first problem was ascertaining if the state of diversification in 1939 warranted placing that year in Stage I and proceeding from there under the assumption that subsequent years belonged elther to this or to later stages.

Table 3 shows the frequency distributions from which the mean Gini coefficlents for 1939, 1949, and 1959 were computed. The means are shown in the last row. This table should be used with chart III for the analysis.

In view of the wide range in diversification as shown In the table and in light of the trend toward increasing diversification in the 1939-49 and 1949-59 decades, It was 


\section{CHART III}

SOURCES OF CASH INCOME, GEORGIA, 1929-59

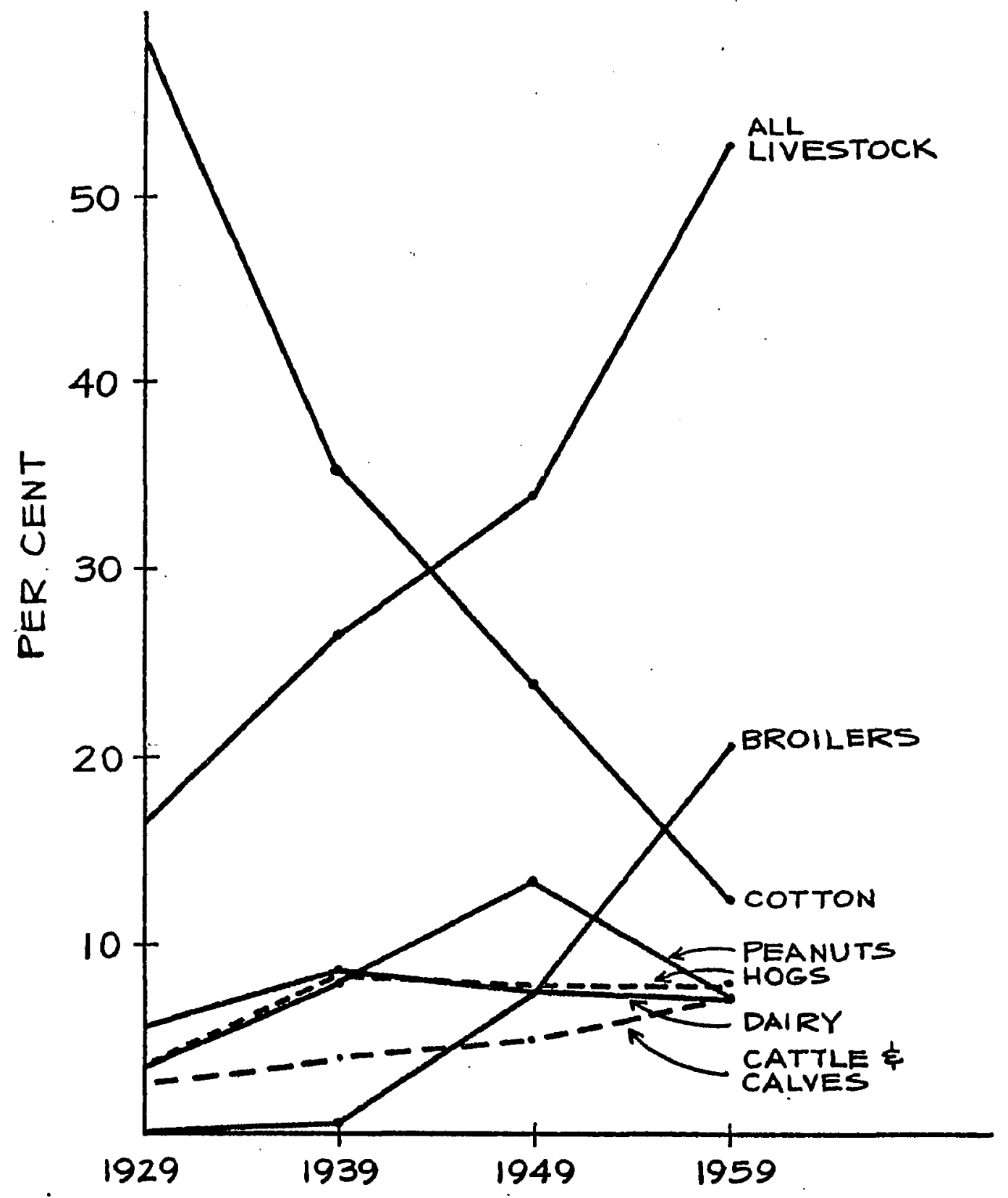


TABLE 3

FREQUENCY DISTRTBUTIONS OF GINI COEFFICIENTS

OF DIVERSIFICATION BASED ON VALUE

OF FARM PRODUCTS SOID,

1939, 1949 AND 1959

\begin{tabular}{cccc}
\hline Gin1 Coefficients & $\begin{array}{c}1939 \\
f\end{array}$ & $\begin{array}{c}1949 \\
f\end{array}$ & $\begin{array}{c}1959 \\
f\end{array}$ \\
\hline $.30-.39$ & 0 & 2 & 0 \\
$.40-.49$ & 1 & 7 & 6 \\
$.50-.59$ & 8 & 11 & 11 \\
$.60-.69$ & 22 & 23 & 33 \\
$.70-.79$ & 42 & 36 & 36 \\
$.80-.89$ & 31 & 23 & 15 \\
$.90-.99$ & 1 & 3 & 4 \\
\hline Neans & 105 & 105 & 105 \\
\hline
\end{tabular}

postulated that the state as a whole was in stage I in 1939, was entering Stage II by 1949, and was well along in Stage II by 1959. The confirmation of such a postulate meant that there was a lag in diversiflcation based on income diversification. Reasons for these stage identifications are given below.

The state of diversiflcation in 1939 was almost identical with the 1deal construct of Stage $I$. There were high Gini Coefficients and a decided concentration of cotton in the Income structures all over the state except in the southwest Coastal Plain. One-third of all 105 countles had Gini Coefficients equal to or greater than .80 and in this 
same year the mean value was .742 . In four-fifths of the 53 Pledmont counties and in all of the counties of the eastern Coastal Plain, cotton was the highest ranking source of income. Moreover, in a majority of these count1es, cotton accounted for over one-half of total cash farm recelpts. The dominant role played by cotton as an earner of farm income is also shown in chart III. The position of peanuts In the southwest Coastal Plain was equally commanding, although in the southernmost counties, SEA $7 \mathrm{~b}$, the income from peanuts was about equal to that from tobacco. Thus, Map XVII understates the diversification to this extent. According to Table 3 diversification was greater in 1949 than in 1939. The mean ain1 coefficient of .707 in 1949 was significantly lower than that of .742 in 1939. The level of significance of this difference was at least 5 per cent. In addition, only 60 per cent of the counties in 1949 had Gin1 coefficlents greater than . 70 , compared with 70 per cent of the counties in 1939. The rate of increase in these coefficients between 1949 and 1959 was observed to have been smaller than that for the 1939-49 decade. Th1s meant that after 1949 the rate of increase in diversification was at a decreasing rate and that the state had entered into State II. Apparentiy, the rate of increase in the Ginf coefficient had reached a maximum by 1949 and was hence past the first inflection point on the theoretical curve of stages of diversification. 
Nevertheless, in 1949 there was st1ll considerable concentration based on the same commodities--cotton and peanuts--as in 1939. Cotton was the major source of income In about two-fifths of all counties outside the western half of the Coastal Plain. Peanuts accounted for at least one-half of the farm cash recelpts in most of these southwest counties except in SEA 7b. Moreover, In about one-third of the counties studied, cotton represented one-third of cash income. Yet, poultry sales had risen to a commanding position in the northern Pledmont and dairying was becoming increasingly dominant in the central Pledmont. Whether the prerequisite for the dominance of cotton in the income structure is set at 50 or 40 per cent of total cash income, the overall plcture in 1949 warranted placing this year in the early part of Stage II.

By 1959, 1t seemed clear after inspecting Maps XXII and XXIII, that the state as a whole was in Stage II. Not only did a falling rate of increase in diversiflcation indicate that maximum diversification was near or in this year, but also changes within the income structures indicated a shift toward increased importance of 1 ivestock and I1vestock products at the expense of the traditional row crops. The average Gini coefficlent in 1959 was essentially the same as in 1949. However, in 1959 there were only 19 counties with Gin1 coefficients in excess of .80 as compared to 26 
such counties in 1949. The largest change was in the .60-.69 category, where a gain of 10 counties in the 1949-59 decade was registered.

Transformation within the income structures was more remarkable. Cotton, the ranking source of income in over one-half of the 105 counties in 1949, was of such importance in only 15 per cent of the counties by 1959. Most of these were core cotton-producing count1es. This difference in proportions was significant at the one per cent level. Furthermore, almost one-third of the counties had no cotton in their income structures.

A reglonal analysis throws light on the nature of this competition between cotton and other products and is instructive in 1 ts own right because some parts of the state have made stage advances beyond others.

The severest competition faced by cotton has been in the northern Pledmont. Already dominant in a few counties here in 1949, poultry production had grown to such an extent that it represented at least one-half the cash recelpts from all commodities in SEA 3. Th1s "Poultry Belt" had moved ahead of the rest of the state into Stage III by 1959.

Farther south, another group of counties-Monroe, Putnam and Morgan are the best examples--were moving at a slower rate but in the same direction toward increasing concentration. Sales from dalry products were the primary source of income. The two core cotton-producing regions lagged behind the rest of the state in their stage progression. Both the 
1939-49 and 1949-59 trends had been toward diversification, indlcating that they were in Stage II or at some point before maximum diversification had been reached. A simllar retardation was noted earlier in the case of land use diversification.

There was some indication that the southwest Coastal Plain was about to repeat the first three stages of the diversification curve. From data on the acreage of peanuts and cotton in these counties and total volume of peanut sales for the state (Chart II) it was postulated that the cotton dominant stage was reached prior to 1939 , and that a maximum of diversification occurred around 1939. These stages were I and II, respectively. By 1949 Stage III with a maximum concentration of peanuts had been reached and by 1959, a "Stage IIa" was inciplent. In this latter year hogs had become more Important, cotton had slightly improved 1ts pos1tion over the 1939-49 decade and the relative value of the sale of peanuts had declined. Even poultry sales had grown to the extent that they could be shown in the income structures in several of the counties.

That the status of diversification of the three years selected here can be Identifled with some stage of diversification cannot be denled. However, the exploratory nature of this study ruled out rigorously proving or disproving the stage into which any year fell. Not enough years were used to determine when maximum and minimum points of diversification 
were reached. And even if a larger number of years had been used, the characterizations of the stage were not clear cut and objective enough to permit reliablity tests by other Investigations. Even if the approach to diversification through stages was nothing more than a heuristic device It has provided a useful framework for analyzing agricultural changes . 


\section{CHAPTER V}

\section{AGRICULTURAL DIVERSIFICATION AND SELECTED SOCIOECONOMIC VARIABLES}

It $1 \mathrm{~s}$ the purpose of this chapter to determine the relationship of selected socioeconomic variables to agricultural diversification and to learn if something is to be gained from relating diversification to a broader complex of socloeconomic variables, all of whlch are presumed to have some bearing on diversiflcation, statistically.

Agricultural diversification for 1959 is broken down Into two variables: one based on land use and the other on the value of farm products sold. These two varlables are designated as criterion variables and the alm of this chapter is to ascertain how these criterion variables are related to the other selected varlables. The 28 other socloeconomic varlables used in this analysis follow:

1. Percentage of farms nonwh1te, 1960

2. Percentage of farmers tenants, 1960

3. Percentage of white farmers tenants, 1960

4. Percentage of nonwhite farmers tenants, 1960

5. Percentage of farms having tractors, 1959

6. Percentage of families and unrelated individuals having income less than $\$ 3,000,1960$ 
7. Percentage of population nonwhite, 1960

8. Percentage of commercial farms with less than $\$ 2,500$ value of farm products sold, 1959

9. Percentage of population urban, 1960

10. Percentage of cropland in cotton, 1959

11. Average farm size in acres, 1959

12. Number of farm operators working off-farm more than 100 days, 1959

13. Level of living of farm operators, 1959

14. Hydrocarbon consumption per acre, in tens of cents, 1959

15. Number in labor force, in thousands, 1960

16. Retall sales, in millions of dollars for establishments with payrolis, 1960

17. Value of bulldings and farms per farm, in hundreds of dollars, 1959

18. Value of farm products sold per farm, in hundreds of dollars, 1959

19. Number in manufacturing, in hundreds, 1960

20. Percentage change in total population, 1950-60

21. Percentage change in rural population, 1950-60

22. Change in level of living of farm operators, $1939-49$

23. Change in number of farms over 500 acres, 1939-59

24. Change in number in manufacturing, in hundreds, $1940-60$

25. Change in c1vilian labor force, in hundreds, 1950-60

26. Outmigration of nonwh1tes, 1940-50

27. Change in value added by manufacturing, in millions of dollars, $1940-58$ 
28. Change In value of farm products sold, in tens of thousands of dollars, $1949-59^{1}$

The method used to assess the interassociation among these 30 variables is factor analys1s. The factor analysis begins with the simple correlation matrix of all the variables. Use of this technique made it possible to collapse the original 30 variables into ten factors which accounted for four-fifths of the variance of the original set. At the same time, the extent of the relationsh1p between the factors on the one hand, and the two criterion variables on the other, was established. Thus, the factor solution contributes to an understanding of the interrelationship among the several variables through an analysis of their relationship to several factors which are common to most of the varlables. Varlous methods of factor analysis exist, all of which are designed to reduce a larger number of varlables to a smaller number by finding the common threads running through the original set. The main differences among the various methods of factor solutions are based on three conditions.

The first condition is the contribution of the factors to the total variance of the correlation matrix. Some methods are designed to select the first factor in such a manner that It accounts for the maximum of the total variance and that successive factors account for decreasing amounts.

The second condition relates to the sophistication of

1

The source of these data is varlous United States Census publications on Population, agriculture, and manufacturing. 
methods of grouping the variables. Methods of grouping the varlables may range from simple graphic devices to more mathematical y rigorous methods of factor extraction.

The third condition relates to the system or representing the variables. In one system, each variable may be represented as a vector where the angular separation between pairs of vectors is inversiy proportionate to the correlation between the pairs of variables. On the other hand, one point may represent an Individual score or value projected onto as many references as there are varlables. The compression of a larger number of variables into a smaller number which can account for most of the variance of the larger set is represented in the factor atructure. For any vartable $z_{j}$, it can be shown that

$$
z_{j}=a_{j 1} F_{1}+a_{j 2} F_{2} \cdot \cdot a_{j m} F_{m}
$$

where $m$ is the number of common factors $F_{1}$, and $a_{j 1}$ $\left(1=1,2, \ldots\right.$ m) is the loading of variable $z_{j}$ on factor $F_{1}$. The matrix consisting of all the loadings of every variable on all the factors is called the factor structure. The loadings may be vlewed from two points of view. First, the loading of variable $z_{j}$ on $F_{1} 18$ the correlation between this variable and this factor when the factors themselves are uncorrelated. Second, the loadings may be consldered as regression coefficients in a regression equation with the Fis considered as independent variables. The summation of these squared loadings,

$$
\sum_{i=1}^{m} a_{j i}^{2}
$$


1s defined as the communality of variable $z_{j}$, or $h_{j}^{2}$.

The communality may be regarded as that portion of the variance of a variable which is common to other variables in the factor analyo1s. The problem of communalities is crucial for at least two reasons. F1rst, there is not a priori knowledge of their values before making the factor analysis. Their values must be estimated before obtalning a factor solution. Second, their estimated values determine the proportion of unit variances factored into common factors. 2

The Interpretation of the factors is based on the loadings of the variables on the factors. Often the initial factor solution is inadequate as the final analysis of a correlation matrix from the standpoint of interpretability of the factors. It 18 necessary then to transform the original solution to a different frame of reference. This involves the rotation of the initial axes or dimension of the given factor solution. In attempting to reduce the complexity of the factorlal description of the variables, rotation is designed to achieve a "simple structure," or a condition where each factor w1Il have at least m zero loadIngs in the factor structure while the remaining loadings are as high as possible.

The factor analysis solution employed in this dissertation 18 the princlpal axes method. Developed by

${ }^{2}$ Harry H. Harman, Modern Factor Analys 1s (Chicago: The University of Ch1cago Press, 1960), p. 69. See Chapters II and $\mathbf{V}$. 
Hotelling in the 1930 's, this solution is based on the point representation of the variables, where there is one point for each of the $\mathbb{N}$ Individuals ( 105 counties in this case) and each point is referred to a coordinate system consisting of as many axes as there are variables ( 30 variables in this case). A new axis is fitted in such a way that this axis accounts for the maximum amount of variance of all the variables. This new axis becomes the first factor. Stated geometrically, the value of the projections of the original points on this new axis exceeds that for all other axes that could have been chosen. All succeeding factors account for decreasing proportions of the total variance. Moreover, the principal axes solution has the advantage of giving a mathematically unique solution.

In the principal axes method used here the communalities are estimated on a basis of the squared multiple correlation of each variable with the remalning $n$ - 1 observed variables. It is true that the insertion of these squared multiple correlations (SMC'B) in the diagonals produced a correlation matrix that was not strictly Gramian. However, some other properties of the SMC's apparently of fset th1s disadvantage. First, the SMC's converge toward the communalities determined from the factor structure after repeated 1terations. Second, the SMC's are less than or equal to the communalities. The latter advantage makes it possible to determine the direction of the error in the estimated communalities. By using the estimated communalities in the 
diagonals of the original correlation matrix instead of unities, the factor solution derived in this study had fewer factors than variables. This condition combined with the fact that the first three factors accounted for over half the total varlance of all the variables effected considerable parsimony in interpreting the intercorrelations of the variables. Furthermore, the estimated communalities on a basis of the SMC's assumes the existence of unique variance, that is variance unique to each specific variable. 3

The varimax method of rotation of axes was used here, primar1ly because it was the only avallable one for which a -computer program was obtainable. However, its advantages have been pointed out in the literature. First according to Harman, " ... It tends to definitize mathematically the intuitive notion of simple structure."4 second, Harman discusses works that substantiate the property of Invariance Inherent in the varimax method, whereby the factorial description of a variable tends to remain invariant when the variable is moved from one set to another involving the same common factors. The varimax method compares favorably with the quart1max and graphic methods in regard to its ab1lity to determine a simple structure.

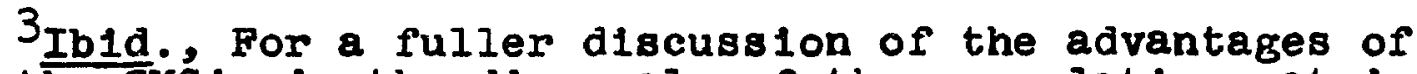
using the SMC's in the diagonals of the correlation matrix see Chapter $V$ in Harman.

${ }^{4}$ Ib1d., p. 307 .

5Ib1d., See Chapter XIV and p. 307 in particular. 
The principal axes solution ylelded uncorrelated factors that maintained this orthogonality even with the varimax rotation. Only ten factors were extracted out of a possible total of 30 . But these ten factors accounted for slightly over four-fifths of the total variance of the orlginal set of 30 . The first factor accounted for 30 per cent of the total amount of variance. The second, third, fourth, fifth, and sixth factors accounted for $11,10,9,6$, and 5 per cent of the total variance, respectively. No other factor contributed more than three per cent to the total variance. The factor solution does not provide specific names of the derived factors. The names given to the factors are based on an interpretation of the loadings in the factor structure. Table 4 below reproduces part of this factor structure, namely the loadings of the variables on the first $81 x$ factors. The numbers of the varlables correspond to those listed with the variables at the beginning of this chapter. The two criterion variables are numbered 29 and 30 and they are the only ones not listed above. Variable 29 is land use diversification based on the alni coefficlents for 1959; varlable 30 is income diversification based on Gini coefficlents for the same year. Naming the factors on a basis of the variable loadings 1s subject1ve, but necessary. Factor I had a high loading on those varlables assoclated with urbanization--retail sales, change in value added by manufacturing, size of labor force--and low or negative loadings on the varlables that 
TABIE 4

FACTOR LOADINGS FOR THE FIRST

SIX FACTORS*

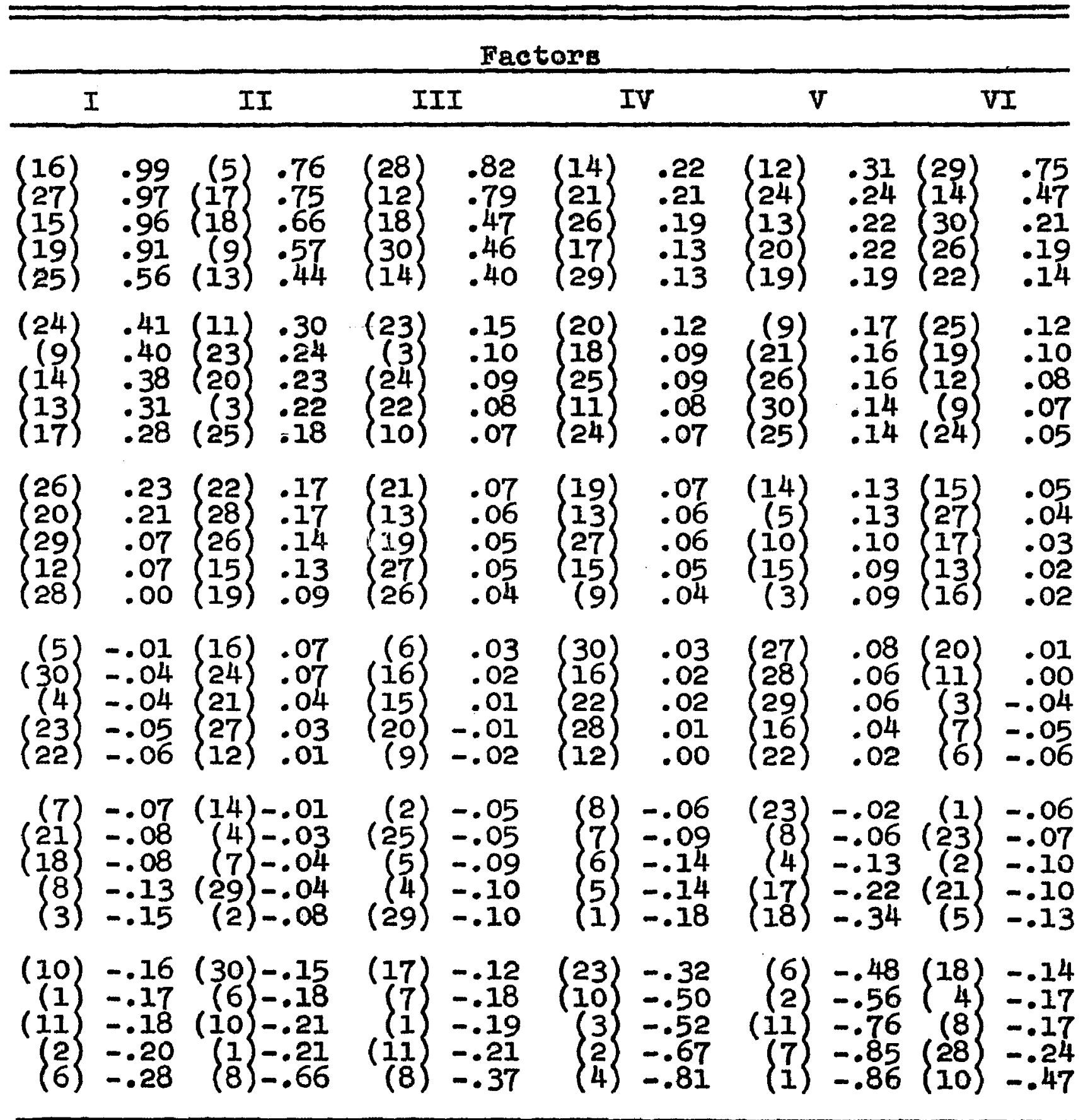

*The variables, shown in parenthesis, are followed by the loadings. 
could be said to represent static agriculture. Names suggested for this factor are dynamic urbanism and dynamic commerce.

Factor II has relatively high loadings on variables assoclated with economic development of agriculture--farms with tractors, value of farms and bulldings, and value of farm products sold. The varlable with the largest negative loading was the percentage of commerclal farms with less than $\$ 2,500$ value of farm products sold. This factor was deslgnated as welfare in the farm economy.

Factor III could not be easily distinguished from Factor II. Both had low loadings (negative) on the per cent of commerclal farms w1th less than $\$ 2,500$ value of farm products sold. Change in value of farm products sold and the number of farmers working off farm more than 100 days were the two variables with the highest loadings on Factor III. Maximum values of these two variables are found in the northern Pledmont in and adjacent to the "Poultry Belt". It could be that labor intensive cotton farming gave way to capital intensive poultry farming, releasing the surplus labor for nonfarm employment, or that a labor deficit created on the farms by an increase in nonfarm employment, or that a labor deficit created on the farms by an increase in nonfarm employment opportunities necessitated a shift to more capital Intensive farming. A suggested name for this factor was evolution in the agricultural economy. 
The name of Factor IV was determined on a basis of the negative loadings instead of the positive ones because the latter were so low. The correlation between the percentage of nonwhite farmers classed as tenants and this factor was -.81. Other variables with a high loading on the negative end of this factor related to tenancy. This factor was therefore, designated as low tenancy intensity.

Similarly, Factor $v$ was designated on a basis of the negative loadings. The percentage of the population classed as nonwhite and the percentage of farms nonwhite had loadings of -.85 and -.86 , respectively on this factor. On the other end of the scale was the number of farm operators working off farm more than 100 days. The greatest concentration of this non farm employment was in the northern Pledmont where the nonwhite population was comparatively small. This factor was designated as low nonwhite concentration.

Factor VI had a high loading on land use diversification--.75. Actually, this was the only varlable where the absolute value of the loading exceeded .50 . The percentage of cropland in cotton had a negative loading of -.47 on this factor. This meant that a relatively high concentration in land use was assoclated with a small proportion of cropland used for cotton. This lent support to the conclusion reached earlier that the core cotton counties were in general more 
diversified than the rest of the state. The consumption of hydrocarbons per acre had a positive loading of .47 on this factor. Here again it appears that this association was due to the concentration of pastured cropland in the same counties emphasizing elther poultry production or dalrying. The major objective of this chapter was to assess the relationship between diversification and the 28 socloeconomic variables given above. From the foregolng analysis, it can be concluded that land use and income diversification are not closely related to the selected varlables. In the case of the first factor, called dynamic urbanism, the loading of land use diversification and income diversification was .07 and -.04 , respectively. Although no tests of significance were made on these correlations, 1t appears that these small loadings were not different from zero. 6 The loading of acreage and income diversification on the second factor was -.04 and -.15, respectively. The h1ghest loading of any one of the two criterion variables on any of the f1rst five factors was .46. This was the loading of income diversification on Factor III, designated as evolution of the farm economy. Since this is one of the highest loadings, further discussion 18 presented below.

6Ib1d., In Chapter XVII Harman discusses techniques for determining if the factor loadings differ from zero in a statisticaliy signiflcant manner. No such significance tests were made in this study. 
The loading of .46 for income diversification on Factor III was not sufficiently high to draw conclusions as to the role that income diversification plays in the economic evolution of the farm economy. However, this loading suggests that a county with a varied source of income tends to be worse off in regard to change in value of farm products sold and to other indices of progressive evolution of the farm sector than one with a high concentration of income. At this point, it should be re-emphasized that the Gin1 coefficlents for both income and areal diversification were used in computing the correlations for the factor analysis. The larger Gini coefficients indicate high concentration rather than high diversification. This loading of .46 on Factor III was primarily due to the situation in the northern Pledmont, where a high concentration of income assoclated with poultry production, and to some extent dairying, was In areas of high farm income and relatively large positive changes in cash receipta. Inspection of Map XXII and Map XXVII helps to point out the implicit relationship between the stage progressions mentioned earlier in reference to Income diversiflcation and this third factor called evolution of the farm economy. The counties of the northern Pledmont had been regarded as being further advanced in the stage progression than other parts of the state as well as ranking high on the third factor. Major exceptions to this 
Cotegories

Millions of Dollars

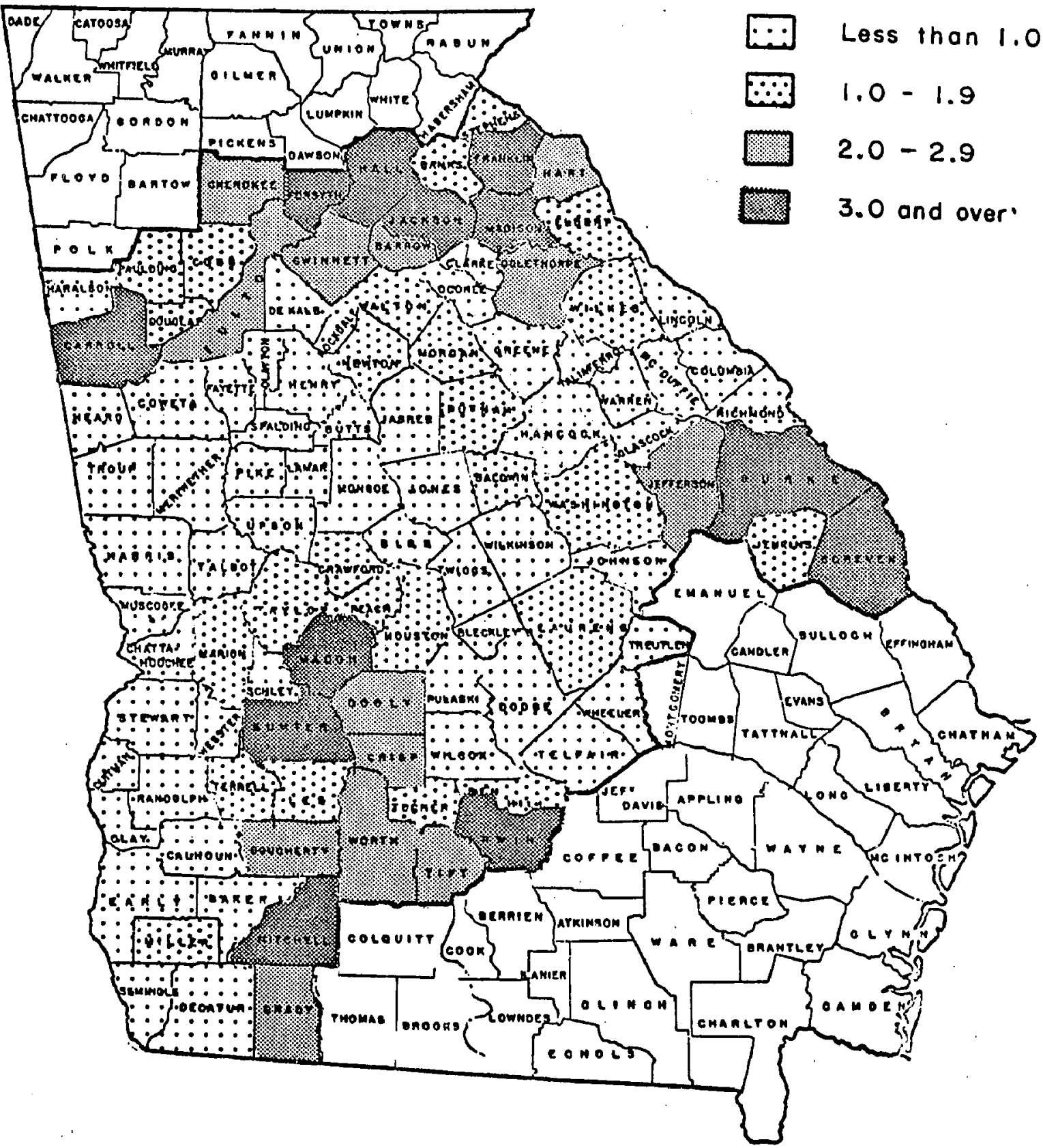

MAP XXVII

CHANGE IN VALUE OF FARM PRODUCTS SOLD FOR 105 GEORGIA COUNTIES, $1949-59$ 
Implicit relationship were seen in Burke and Sumter counties In their high rank in change of value of farm products sold and their being relatively retarded in their stage progression.

of the ten factors extracted, there was only one, other than Factor III mentioned above, on which one of the criterion variables had a high loading. Land use diversiflcation had a loading of .75 on Factor VI. In fact, land use diversification was the name assigned to this factor since the absolute value of the next highest loading was .28 points lower. Hydrocarbon consumption per acre had a correlation of .47 with this factor; the per cent of cropland planted to cotton had a loading of -.47 on Factor VI. Although the absolute value of either of these loadings is not large, they suggest that first, the counties with the highest concentration of landuse tend to consume the greatest amount of gasoline or other fuels, and that counties with the highest concentration of land use tend to have the smallest proportion of 1ts cropland used for cotton production. The second conclusion was noted In the previous chapter, when it was shown that the core cotton producing counties of 1959 were more diversifled than other counties in the study. It was also noted that this condition reflected a lag in stages of land use diversification. Areas with relatively high consumption of gas and oll were mainly around Atlanta, in the poultry belt, and in the major dalrying region. Hydro-carbon consumption was 
assoclated with providing energy or power for these operations. But these were the areas where the dominant land use was for pasture. There was no other varlable with a loading whose absolute value was greater than .24. Thus, there was no substantial association between land use diversification and any of the 29 other varlables except in the case of the two var1ables discussed above.

The conclusion from the factor analysis is that both land use and income diversification have not shown a signiflcant relationship to the other 28 variables. Even in the loading of income diversification on Factor III and the loading of hydro-carbon consumption on the farm and the per cent of cropland in cotton on Factor VI, the degree of association was only slight. A part of the explanation of this condition can be found in the discussion of the stages of agricultural diversification in Chapter IV. The critical aspect of agricultural diversification seems to lie in its continuing on-going character involving decreasing and increasing intensification. Th1s aspect is obscured when diversification is treated as a static condition, arealiy varying, but held constant in time. It may be that change in diversification, qualifled by some value judgement as to whether the change is progressive or regressive, would provide a better framework for a more complete understanding of this phenomenon. The introduction of the more subjective element in the analysis suggests the appropriateness of non-parametric 
statistical devices, such as Ch1-Square tests. However, there has been some merit in using factor analysis. It can be seen that more than one year and more emphasis on change would have likely contributed to a better understanding of diversification and its relationship to the socioeconomic varlables. 


\section{SUMMARY AND CONCLUSIONS}

In this final chapter some of the findings of the study are summarized. Following this some of the implications of these findings in relationship to theoretical and practical concerns of the fleld of geography are presented. A final section deals with some of the limitations of this study and suggests areas for further study and investigation.

Findings

The first alm of this dissertation was to examine spatial variation of diversification based on income and land use for 1939, 1949, and 1959. In the case of land use diversification 1t was concluded that diversification was moderate. Mean GIn1 coefficients for all three years were in the high 50's, or midway between extreme concentration and extreme diversification: A regional analysis focused attention on three groups of highly diversified counties that existed in 1939. One, located in the eastern Pledmont, became more diversifled by 1959. It was also one of those core cotton-producing group of counties where cotton persisted as an important component of the acreage structure for 1939, 1949, and 1959. A second highly diversifled cluster of counties in the central pledmont became more concentrated 
In wake of the expansion of pastured cropland and contraction of cotton acreage. A third highly diversifled zone of the central part of the state in the vicinity of Bibb County maintained its diversity and later captured adjacent counties to the south. Here the land use diversification was based on the role of trees--peaches and pecans--1n the acreage structure. Another distinct region, but one that was highly concentrated, consisted of a cluster of counties in the southwest. First peanuts and later corn dominated the acreage structures in this cluster.

It was found that the general trend of land use in the Pledmont was toward increased concentration except for the eastern Pledmont group of counties mentioned above. This general trend accompanied increased stress on the production of hay, grains, and pastured cropland. In the Coastal Plain, on the other hand, the trend was largely in the direction of increased diversification. This tendency was also effected through the expansion of hay and pastured cropland, and to a more limited extent, through uses of land for legumes, fruit, and trees.

The analysis of diversification based on source of farm income revealed that there was more concentration in this sphere than in the case where diversification was based on land use. Mean GInI coefflcients for diversification based on source of farm income were at least .11 points higher than those based on the diversification of land uses. Reglonal 
analyses were focused on three groups of countles that were highly concentrated in 1939 and another group of counties that had become highly concentrated by 1959 . The first highly concentrated group was in the eastern Pledmont. In fact it was nearly coterminous with one of the three 1slands that ranked high in terms of diversification of land use. Most of these counties were classifled as core cottonproducing areas. Unt1l the poultry Invas1on, between 1949 and 1959, cotton was the primary source of income. The second highly concentrated cluster of counties centered on the easternmost counties of the Atlantic Coastal Plain. Cotton was the dominant source of income in these counties too. The third highly concentrated cluster of counties was the one centered on the peanut growing district of the southwest Coastal Plain. Livestock production had weakened the dominant position of peanuts by 1959 and corn had displaced peanuts as the leading crop in the acreage structure of most of these counties. The highly concentrated area that emerged In 1959 was in the northern Pledmont where poultry had become the dominant source of income by that time. The second alm of this study was to evaluate the hypothesis that diversification in the core cotton-producing count1es, as determined by Prunty, was less extensive than In other parts of the state. As regards areal diversification, this hypothesis was rejected. In fact it was found that the core cotton-producing counties were more diversifled than 
the remainder of the state in some years. Even where this was not true, the Iimited concentration was the result of the commanding position of corn or some other land use rather than cotton.

On the other hand, In the case of income diversification, the hypothesis was accepted, particularly for 1939 and 1949. These core cotton-producing counties were more concentrated and this was true primarily because of the prominent position of cotton in the income structure. By 1959. however, these countles had become more diversifled with a concomitant weakening of the position of cottion.

The third aim of this study was the 1dentification of stages of diversification on a basis of a hypothetical model. The examination of the status and changes of areal and income diversification for the three years made it possible to assign the state, or a portion of the state, to one of the three basic stages in each of the three years.

In regard to diversification based on land use, it was found that only the highly diversifled core cotton-growIng counties could be placed in Stage II (Chart I, p.115). According to the hypothetical model, this was the stage where maximum diversification in a time sequence was presumed to exist. Most of the remainder of the state was tentatively placed in the early part of Stage III, or the later part of Stage II. Stage III was defined in the model as one where concentration was elther increasing or had reached a maximum. 
The concentration of pastured cropland in the Pledmont and corn elsewhere seemed to have warranted placing most of the counties in the early part of Stage III. A Stage Ia was suggested for the southwest Coastal Plain on a basis of the 1959 data because the declining Importance of peanuts in the acreage structures had partly resulted in greater diversification here.

In regard to income diversification, most of the state was placed in Stage I in 1939. Cotton was then the dominant source of income in three-fourths of the counties, the southwest Coastal Plain excepted. Increased diversification in 1949 and in 1959 accompanying the declining role of cotton in the income pleture warranted placing most of the counties in Stage II in these two years. It appeared that in the northern Pledmont, where poultry sales dominated the income structures of most counties and in the central Pledmont where dalrying had emerged as a primary source of income, Stage III had been reached by 1959 .

The last objective of this dissertation was to assess the relationship of 28 socloeconomic variables to diversification. The two diversification indices that were used for the 1959 data. Of the ten factors derived by the principal axes analysis of the two criterion variables based on income and land use diversification and the other variables, it was found that only one factor was correlated with either of the 
two criterion variables. ${ }^{1}$ This factor was designated as evolution of the farm economy, mainly because of the high loading that change in the value of farm products sold had on 1t. The factor had a correlation of .46 with diversification based on source of income. The interpretation of this association was that in counties where the income was concentrated from one source, there was a tendency for them to have a large absolute change in the value of farm products sold. It was the concentration of income from poultry sales rather than cotton sales that accounted for the correlation between this factor and income diversification.

\section{Implications}

No conclusion should be made without considering the Implications of these findings to the broader theoretical framework and practical considerations of the fleld of geography. The concept of reglonalization is of practical and theoretical value to the geographer who is faced with the task of ordering and systematizing complex spatial variation. Another implication of the findings of this dissertation relates to the relative merits of the theoreticaldeductive approach to solving problems in agricultural geography.

Baker and Whittlesey attacked the problem of systematizing spatial data relating to agriculture by delineating

Isince the sixth factor was designated as agricultural diversification (concentration) based on land use, it is omitted here. 
agricultural regions; present day geographers attempt to resolve the problems through the determination of spatial systems. Regardless of the approach, if the concept of reglonalization is to retain its usefulness, its dynamic character must be recognized. The boundarles and character of regions must constantly be re-evaluated.

The findings in this study have provided a basis for a re-evaluation of what was designated as the Cotton Belt by Baker and Whittlesey in the 1920's and what was described as core cotton growing regions, considerably reduced in area and more fragmented, by Prunty 20 years later. Using the Prunty criterion of the proportion of farm land used for growing cotton, only counties, or less than onefifth of the 105 counties studied here qualified as core cotton producing regions in 1959. Th1s small number of core cotton-producing counties in 1959 was indicative of even further shrinkage of the major cotton growing reglons within the cotton core-producing regions ldentifled by Prunty. Moreover, by 1959, cotton was a leading land use in only three of these 21 counties and the primary source of income in only seven of them. In not one of the counties where cotton was the leading land use was it the major source of Income, and in not one county where it was the major source of income was it the leading land use. On a basis of these conditions, it is difficult to see how designating any part 
of the area studied here as a part of a cotton Belt or even a core cotton-producing region can be justifled, even for pedagogic reasons.

The basic approach to solving the problems of this dissertation was empirical-inductive, that is, inferences and conclustons were based on the collected and analyzed data. The use of the model of stages of diversification was fundamentally a theoretical-deductive approach. The model embodied the theory that was postulated at the outset. Purther steps Involved determining how the actual data agreed with the theory. Thus, the theory preceded, not followed, the analysis of the data. Because the model was not rigorously defined in this study, Its primary utility was in its function as a heuristic device. The lag of the core cotton-growing regions behind the rest of the state in regard to agricultural development would have been obscured without using an approaish of this type. Hence, the spatial and temporal relations of agriculture in Georgia were described more sat1sfactorily.

Suggestions for future study

Pointing out some of the limitations of this study provides a basis for suggestions of likely areas for further research. Recognition of such limitations may also contribute to improvement in research designs for future studies of this sort.

The value of this dissertation would have been enhanced 
if the model of agricultural stages had been more rigorously and objectively defined. While the value of the model as a heurlstic device cannot be denied, it appears that it has greater potential use as an analytic device. The number of years considered must be increased in order to define the stages more objectively.

Another serlous drawback of this dissertation revolved around the use of counties as the basic unit of study. The first problem is one of county size variation. Where correlation techniques are used, the problem becomes obvious as the area becomes an extraneous variable automaticaliy introduced into the correlation analysis. A second problem with the use of county data related to the problem of contigulty. For continuous areal units such as counties, values in one county are not independent of values in adjacent counties. A third drawback of the use of counties as units of investigation Inheres in the impossibility of drawing meaningful conclusions about the Individual units making up the county. For example, Hart County derived nearly one-half of 1ts income from the sale of poultry products, yet one-sixth of the farmers classifled as poultry farmers accounted for the bulk of these cash recelpts.

It 18 suggested that further studies give more attention to the problems of the use of county data. Moreover, more atudy is needed in the area of agricultural diversification where the Individual farm is the unit of study. 
Another Iimitation of this study was that the factor analysis falled to utilize all means to uncover more meaningful relationships between diversification and the selected socioeconomic variables. Pallure to use the diversiflcation Indices for all three years along with the socloeconomic varlables computed for these years no doubt obscured relationships that were meaningful only in a temporal framework. Additional effort is recommended to make the factor analys is contribute more to an understanding of areal variation between the factors, on one hand, and the diversification indices, on the other. If the factor analysis had been taken one step further by computing the factor scores which show how each county is loaded on the factors, it would have been easier to ascertain the spatial variation of the factors. Regressing the indices of diversification against the factor scores would have contributed to a better understanding of the relationship between the factors, on one hand, and the indices of diversification, on the other hand. In following such a procedure the indices of diversification may have been om1tted from the factor analysis. Future studies may experiment with the $Q$-mode factor analysis instead of the $R$-mode type of analysis as used here. In the Q-mode analysis, the counties rather than the variables are compressed and the factor loadings indicate the similarity existing among the counties and hence give clues to reglonalization with regard to the varlous varlables. 


\section{BIBIIOGRAPHY}

Baker, 0. E. "Agricultural Regions of North America," Economic Geography, II (October, 1926), pp. 459-93.

Bogue, Donald J. and Beale, Calvin I. Economic Areas of the United States. New York: The Free Press of GIencoe, Inc., 1961.

Christensen, Raymond P. and Aines, Ronald O. Economic Effects of Acreage Control Programs in the I950's. United states Department of AgricuIture, Agricultural Economic Report No. 18. Washington: United States Government Printing Office, 1962.

Cooke, C. Wythe. Geology of the Coastal Plain of Georgia. Bulletin of the United States Geological Survey No. 941. Washington: Un1ted States Government Printing office, 1943.

- Physical Geography of Georgla. Georgia Geologlcal Survey Bullet In No. 4. AtIanta, 1925.

Bureau of Labor Stat1stics. Employment and Earnings. Vol. IX, July, 1962.

Ford, K. E. The Supply, Price, Value, and Disposition of Peanuts. Georgia Agricultural Experiment Stations, University of Georgia College of Agriculture Mimeo Series N. S. 143. Athens, 1962.

Glasser, Gerald J. "Variance Formulas for the Mean Difference and Coefficient of Concentration," Journal, Journal of the American Statistical Association, IVII (September, 1962), pp. 648-54.

Harman, Harry H. Modern Factor Analysis. Chlcago: The University of Chicago Press, 1960 .

H1gbee, Edward. American Agriculture: Geography, Resources, and Conservation. New York: John Wiley and Sons, 1958.

La Farge, Lawrence. Physical Geography of Georgia ("The Central Upland" and "Provinces of Appalachian Georgia," Georgia Geological Survey Bulletin No. 42). Atlanta, 1925. 
LeGrand, H. E. and Fucron, S. S. Geological and Ground Water Resources of Central-East Georgia. Georgia Geological Survey Bulletin No. 64. AtIanta, 1956.

- Geology and Ground Water Resources of the Macon Area. Georgia Geological survey Bulletin No. 72. Atlanta, 1962.

Prunty, Jr., Merle C. "Land Occupance in the Southeast," Geographical Review, XIII (July, 1952), pp. 439-61.

"Recent Quantitative Changes in the Cotton Regions of the Southeastern United States," Economic Geography, XXVIII (July, 1951), pp. 189-207.

- "The Woodland Plantation as a Contemporary Occupance Type in the South," Geographlcal Revlew, IV (January, 1963), pp. 1-21.

Schultz, Theodore W. "Reflections on Poverty Within Agriculture," The Journal of Political Economy, LVIII (February, 1950), pp. 1-15.

Sisk, Glenn N. "Agricultural Diversification in the Alabama Black Belt," Agricultural History, XXVI (April, 1952), pp. $42-45$.

So1ls and Men: Yearbook of Agriculture, 1938. The United States Department of Agriculture (washington: The United States Government Printing office, 1938).

Stevens, Rayfred and Brandao, Paulo Reboucas. "Diversification of the Economy of the Cacao Coast of Bahia, Brazil," Economic Geography, XXXVII (July, 1961), pp. 231-52.

Treanor, Kenneth. Georgla's Agricultural Outlook, Georgla Agricultural Extension Service Circular, No. 353 (Athens, 1948).

United States Bureau of the Census. United States Census of Agriculture: for years 1945, 1949 and 1959, see the volumes for Georgia.

- Census of the United States on Population for 1930, 1940, and 1950, see the volumes for Georgia. 
Un1ted States Department of Agriculture. Agricultural Stat1stics for years, 1952 and 1963 Washington: United States Government Printing Office, 1964).

United States Department of Commerce. County and Data Handbook. For years 1952 and 1962 (Washington: United States Government Printing Office).

Weaver, John C. "Crop-Combination Regions in the Middle West," Geographical Rev1ew, XIIV (Apri1, 1954), pp. $175-200$.

Whittlesey, Derwent. "Major Agricultural Regions of the Earth," Annals of the Assoclation of American Geographers, XXVI (September, 1936), pp. 199-240. 